\title{
Impact of Alternate Fuels on Industrial Refractories and Refractory Insulation Applications
}

\section{An Assessment}

\author{
G. C. Wei \\ V. J. Tennery
}




\section{DISCLAIMER}

This report was prepared as an account of work sponsored by an agency of the United States Government. Neither the United States Government nor any agency Thereof, nor any of their employees, makes any warranty, express or implied, or assumes any legal liability or responsibility for the accuracy, completeness, or usefulness of any information, apparatus, product, or process disclosed, or represents that its use would not infringe privately owned rights. Reference herein to any specific commercial product, process, or service by trade name, trademark, manufacturer, or otherwise does not necessarily constitute or imply its endorsement, recommendation, or favoring by the United States Government or any agency thereof. The views and opinions of authors expressed herein do not necessarily state or reflect those of the United States Government or any agency thereof. 


\section{DISCLAIMER}

Portions of this document may be illegible in electronic image products. Images are produced from the best available original document. 
Printed in the United States of America. Available from National Technical Information Service

U.S. Department of Commerce

5285 Port Royal Road, Springfield, Virginia 22161

Price: Printed Copy $\$ 5.50 ;$ Microfiche $\$ 2.25$

This report was prepared as an account of work sponsored by the United States Government. Neither the United States nor the Energy Research and Development Administration/United States Nuclear Regulatory Commission, nor any of their employees, nor any of their contractors, subcontractors, or their employees, makes any warranty, express or implied, or assumes any legal liability or responsibility for the accuracy, completeness or usefulness of any information, apparatus, product or process disclosed, or represents that its use would not infringe privately owned rights. 


\title{
Contract No. W-7405-eng-26 \\ METALS AND CERAMICS DIVISION
}

IMPACT OF ALTERNATE FUELS ON INDUSTRIAL REFRACTORIES AND REFRACTORY INSULATION APPLICATIONS

AN ASSESSMENT

G. C. Wei and V. J. Tennery

\section{SEPTEMBER 1976}

\author{
Prepared for
}

Division of Industrial Energy Conservation ENERGY RESEARCH AND DEVELOPMENT ADMINISTRATION

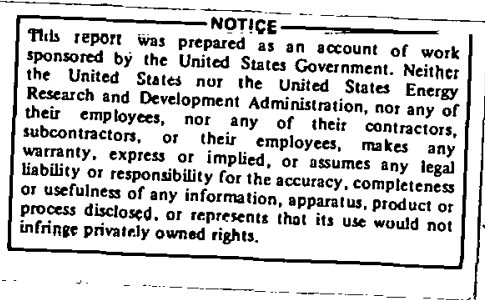

OAK RIDGE NATIONAL LABORATORY

Oak Ridge, Tennessee 37830

$$
\text { operated by }
$$

UNION CARBIDE CORPORATION

for the

ENERGY RESEARCH AND DEVELOPMENT ADMINISTRATION 
THIS PAGE

WAS INTENTIONALLY

LEFT BLANK 


\section{ACKNOWLEDGMENTS}

Many people have contributed to the work described in this report. The authors wish to particularly thank R. W. Anderson of ERDA's Division of Buildings and Industry, and R. G. Donnelly of ORNL, who is manager of the program of which this work is a part. Thanks are also due to numerous people in the industries assessed as part of this work who were generous with their time during telephone conversations and our personal visits with them. The authors would like to thank C. S. Yust and $D$. P. Stinton of ORNL for reading and commenting on the text of the report.

We express our appreciation to Vernell Moore and Gail Smith for their expertise in typing and assembling the report. Finally, we wish to express our appreciation to those who helped in the final preparation and dissemination of this report, including George Griffith, Technical Editor, the staff of the Metals and Ceramics Division Reports Office headed by Meredith Hill, the staff of the ORNL Reproduction Department under Brena Stevens, and Lowell Langford of the Laboratory Records Department. 
THIS PAGE

\section{WAS INTENTIONALLY \\ LEFT BLANK}


CONTENTS

ACKNOWLEDGMENTS . . . . . . . . . . . . . . . . . . . . • . iii LIST OF FIGURES . . . . . . . . . . . . . . . . . . . . . . . . vii LIST OF TABLES . . . . . . . . . . . . . . . . . . . . . . ix SUMMARY . . . . . . . . . . . . . . . . . . . . . xi

1. INTRODUCTION . . . . . . . . . . . . . . . . . . . 1

2. CONCLUSIONS AND RECOMMENDATIONS . . . . . . . . . . . . . 7

2.1 CONCLUSIONS . . . . . . . . . . . . . . . . 7

2.2 RECOMMENDATIONS FOR SELECTION OF REFRACTORIES FOR USE WITH ALTERNATIVE FUELS . . . . . . . . . . . . . . 10

3. ALTERNATE FUELS FOR THE IMMEDIATE TERM $(1976-1980)$. . . . . 13

3.1 DISTILLATE OILS . . . . . . . . . . . . . . . 15

3.2 RESIDUAL OILS . . . . . . . . . . . . . . . 20

$3.3 \mathrm{COAL}$. . . . . . . . . . . . . . . . . . . 22

3.4 ELECTRICITY . . . . . . . . . . . . . . . . 25

3.5 LOW BTU GASES . . . . . . . . . . . . . . . 25

3.6 REFERENCES . . . . . . . . . . . . . . . . . . . 27

4. ASSESSMENT BY INDUSTRY OF FUEL CONVERSION IMPACT ON INDUSTRIAL REFRACTORIES AND REFRACTORY INSULATIONS IN THE IMMEDIATE TERM • • 29

4.1 THE CHEMICAL AND PETROCHEMICAL INDUSTRIES . . . . . . . . 30

4.2 THE IRON AND STEEL INDUSTRIES . . . . . . . . . . . 33

4.3 THE ALUMINUM INDUSTRY .. . . . . . . . . . . 35

4.4 THE COPPER INDUSTRY . . . . . . . . . . . . . . . . 36

4.5 THE GLASS INDUSTRY . . . . . . . . . . . . . . . . . . . . . 37

4.6 THE CERAMICS INDUSTRY . . . . . . . . . . . . . . 39

4.7 THE CEMENT INDUSTRY . . . . . . . . . . . . . . . 41

4.8 OTHER INDUSTRIES . . . . . . . . . . . . . . . . 41

4.9 REFERENCES ..................... 43

5. INTERACTIONS OF ALTERNATE FUEL COMBUSIION PTUDUUCTS WTTH

REFRACTORIES AND REFRACTORY INSULATIONS . . . . . . . . . . . 45

5.1 COMBUSTION PRODUCTS FORMATION . . . . . . . . . . 45

5.2 ALUMINOSILICATE SYSTEM . . . . . . . . . . . . . 49

5.3 THE MAGNESIA-CHROME SYSTEM . . . . . . . . . . . . 58

5.4 OTHER REFRACTORY SYSTEMS . . . . . . . . . . . . . 66

5.5 REFERENCES . . . . . . . . . . . . . . . . . 68 
6. ANALYSIS OF DEGRADATION MECHANISMS IN REFRACTORIES AND REFRACTORY MATERTALS . . . . . . . . . . . . . . . . 71

6.1 RESULTS . . . . . . . . . . . . . .... . 71

6.2 INTERPRETATION OF. FIELD TEST RESULTS . . . . . . . . . . . 76

6.3 REFERENCES . . . . . . . . . . . . . . . . . . 78 


\section{LIST OF · FIGURES}

Fig. 3.1. Relative Increase of the Price Index for Fuels and Electricity (Price Index $1967=100$ ). Reprinted with permission form G. C. Gambs, "The Case for Energy Management," in The 1975 Energy Management Guidebook, ed. by the editors of Power Magazine, McGraw-Hil1, New York, 1975.

Fig. 5.1. The Binary $\mathrm{V}_{2} \mathrm{O}_{5}-\mathrm{Na}_{2} \mathrm{O}$ Phase Diagram at Two Oxygen Partial Pressures. Reprinted with permission from R. C. Kerby and J. R. Wilson, Can. J. Chem. 51: 1033 (1973).

Fig. 5.2. Proposed Phase Diagram of the $\mathrm{V}_{2} \mathrm{O}_{5}-\mathrm{Al}_{2} \mathrm{O}_{3}$ System. Reprinted with permission from Phase Diagroms for Cercomists, E. M. Levin, C. R. Robbins, and H. F. McMurdie, eds., p. 124, American Ceramic Society, 1969.

Fig. 5.3. Phase Diagram of the $\mathrm{V}_{2} \mathrm{O}_{5}-\mathrm{SiO}_{2}$ System. Reprinted with permission from Phase Diagrams for Ceramists, E. M. Levin, C. R. Robbins, and H. F. McMurdie, eds,. 1969 Supplement, P. 110, American Ceramic Society, 1969.

Fig. 5.4. Phase Diagram of the $\mathrm{Na}_{2} \mathrm{O}-\mathrm{Al}_{2} \mathrm{O}_{3}-\mathrm{SiO}_{2}$ System. Reprinted with permission from Phase Diagrams for Ceramists, E. M. Levin, C. R. Robbins, and H. F. McMurdie, eds., p. 181, American Ceramic Soclety, 1969.

Fig. 5.5. Phase Diagram of the $\mathrm{V}_{2} \mathrm{O}_{5}-\mathrm{CaO}$ System. Reprinted with permission from Phase Diagrams for Ceramists, E. M. Levin, C. R. Robbins, and H. F. McMurdie, eds., p. 109, American Ceramic Society, 1964.

Fig. 5.6. Phase Diagram of the $\mathrm{V}_{2} \mathrm{O}_{5}-\mathrm{Na}_{2} \mathrm{O}-\mathrm{Cr}_{2} \mathrm{O}_{3}$ System. Binary phase compositions: $I=\mathrm{Na}_{2} \mathrm{O} \cdot 6 \mathrm{~V}_{2} \mathrm{O}_{5}$, II $=5 \mathrm{Na}_{2} \mathrm{O} \cdot 12 \mathrm{~V}_{2} \mathrm{O}_{5}$, III $=\mathrm{NaVO}_{3}$, $\mathrm{IV}=\mathrm{Na}_{4} \mathrm{~V}_{2} \mathrm{O}_{7}, \mathrm{~V}=\mathrm{Na}_{3} \mathrm{VO}_{4}, \mathrm{VI}=\mathrm{CrVO}_{4}$. Reprinted with permission from R. C. Kerby and J. R. Wilson, Can. J. Chem. 51: 1037 (1973).

Fig. 5.7. Phase Diagram of the $\mathrm{V}_{2} \mathrm{O}_{5}-\mathrm{Na}_{2} \mathrm{O}-\mathrm{MgO}$ System. Binary phase composittons: $\mathrm{I}=\mathrm{Na}_{2} \mathrm{O} \cdot 6 \mathrm{~V}_{2} \mathrm{O}_{5}$, II $-5 \mathrm{Na}_{2} \mathrm{O} \cdot 12 \mathrm{~V}_{2} \mathrm{O}_{5}$, III $=\mathrm{NaVO}_{3}$, IV $=\mathrm{Na}_{4} \mathrm{~V}_{2} \mathrm{O}_{7}, \mathrm{~V}=\mathrm{Na}_{3} \mathrm{VO}_{4}, \mathrm{VI}=\mathrm{Mg}_{2} \mathrm{~V}_{6} \mathrm{O}_{17}$, VII $=\mathrm{MgV}_{2} \mathrm{O}_{6}$, VIII = $\mathrm{Mg}_{2} \mathrm{~V}_{2} \mathrm{O}_{7}$, IX $=\mathrm{Mg}_{3}\left(\mathrm{VO}_{4}\right)_{2}$. Reprinted with permission from R. C. Kerby and J. R. Wilson, Can. J. Chem. 51: 1039 (1973).

F1g. 5.8. Phase Dlagram of the $\mathrm{V}_{2} \mathrm{O}_{5}-\mathrm{Cr}_{2} \mathrm{O}_{3}$ System. Reprinted with permission from Phase Diagrams for Ceramists, E. M. Levin, C. R. Robbins, and H. F. McMurdie, eds., p. 130, American Ceramic Society, 1964.

Fig. 5.9. Phase Diagram of the $\mathrm{V}_{2} \mathrm{O}_{5}-\mathrm{MgO}$ System. Reprinted with permission from Phase Diagrams for Cercomists, E. M. Levin, C. R. Robbins, and H. F. McMurdie, eds., 1969 Supplement, p. 89, American Ceramic Society, 1969. 
Fig. 5.10. Phase Diagram of the $\mathrm{CaO}-\mathrm{MgO}-\mathrm{SiO}_{2}$ System. Reprinted with permission from Phase Diagrams for Ceramists, E. M. Levin, C. R. Robbins, and H. F. McMurdie, eds., p. 210, American Ceramic Society, 1964.

Fig. 5.11. Phase Diagram of the $\mathrm{V}_{2} \mathrm{O}_{5}-\mathrm{ZrO}_{2}$ System. Reprinted with permission from Phase Diagroms for Cercomists, E. M. Levin, C. R. Robbins, and H. F. McMurdie, eds., 1969 Supplement, p. 112, American Ceramic Society, 1969. 
Table 3.1. Distribution of Energy Sources in Industrial Heating and Power Applications in 1971.

Table 3.2. Comparison of Natural Gas Supply and Demand (Btu $\times 10^{12}$ )

Table 3.3. Standards for Distillate and Residual Oils, D-396

Table 3.4. Typical Metallic Impurities and Sulfur Content (ppm) in Distillate and Residual oils from Two 0il Companies

Table 3.5. Examples of Ash Composition in a Typical West Virginia Coal and a Montana Coal

Table 3.6. Typical Compositions of Low Btu Gases and Natural Gas

Table 5.1. Invariant Points in the $\mathrm{V}_{2} \mathrm{O}_{5}-\mathrm{Na}_{2} \mathrm{O}_{5}$ Binary System

Table 5.2. Temperatures at Which Aluminosilicate Refractories are Fluxed by $\mathrm{Na}_{2} \mathrm{O}$, and $\mathrm{Na}_{2} \mathrm{O}+\mathrm{V}_{2} \mathrm{O}_{5}$

Table 5.3. Selected Thermochemical Data for Some Refractory Materials

Table 5.4. Invariant Points in the Systems $\mathrm{V}_{2} \mathrm{O}_{5}-\mathrm{Cr}_{2} \mathrm{O}_{3}, \mathrm{~V}_{2} \mathrm{O}_{5}-\mathrm{Na}_{2} \mathrm{O}-\mathrm{Cr}_{2} \mathrm{O}_{3}$, $\mathrm{V}_{2} \mathrm{O}_{5}-\mathrm{MgO}, \mathrm{V}_{2} \mathrm{O}_{5}-\mathrm{Na}_{2} \mathrm{O}-\mathrm{MgO}, \mathrm{V}_{2} \mathrm{O}_{5}-\mathrm{CaO}, \mathrm{V}_{2} \mathrm{O}_{5}-\mathrm{SiO}_{2}, \mathrm{~V}_{2} \mathrm{O}_{5}-\mathrm{Al}_{2} \mathrm{O}_{3}$, $\mathrm{V}_{2} \mathrm{O}_{5}-\mathrm{ZrO}_{2}$

Table 6.1. Tests of $\mathrm{V}_{2} \mathrm{O}_{5}-\mathrm{Na}_{2} \mathrm{O}-\mathrm{SO}_{3}$ Corrosion in Refractories

Table 6.2. Selected Thermophysical Properties of Some Refractory Materials 


\section{THIS PAGE}

\section{WAS INTENTIONALLY \\ LEFT BLANK}




\section{SUMMARY}

Current U.S. industrial planning for conversion to fuels other than natural gas was estimated from February through April 1976, by contacting more than $100^{\circ}$ companies in a number of industries, including: chemical, petrochemical, steel, aluminum, copper, glass, cement, ceramics, and others. The potential effects of planned fuel conversions upon industrial refractory furnace linings and refractory insulations were also assessed by means of personal contacts and investigations of available literature.

The general opinion of those industrial energy users polled in this study was that the future industrial energy supply situation is confused at present, especially in possible areas of governmental control and regulation and that as a result, it is difficult to make any definite plans. Distillate and residual fuel oils were identified as the favored industrial alternate fuels in current. plans. The 1975 and the projected 1979 fuel use by categories for eight energy intensive industries is presented in the following. Although these estimates are only approximate, they do indicate certain trends in each industry regarding fuel conversion. Distillate oils are easiest to use in place of natural gas for many industrial applications. The capital investment for converting from natural gas to distillate oil for most boiler and process heater applications is about twice the investment required to burn natural gas. Conversion to residual oil combustion systems requires an additional capital investment of about $20 \%$ compared to distillate oil systems. Conversion from natural gas to coal combustion costs about four times the capital investment required for natural gas systems. These ratios tend to become smaller as the size of the combustion unit is increased to very large size (e.g., >2 MW).

1975 and Projected 1979 Fuel and Energy Mix for Selected Industries

\begin{tabular}{|c|c|c|c|c|}
\hline \multirow{2}{*}{ Industry } & \multicolumn{4}{|c|}{ Fue1 Type or Energy Source, \% } \\
\hline & Natural Gas & Fuel oils & Coal & Electrical \\
\hline Aluminum & $37(0)^{a}$ & $10(39)$ & $1(1)$ & $52(60)$ \\
\hline Cement & $42(0)$ & $16(5)$. & $34(85)$ & $8(10)$ \\
\hline Ceramics & $68 \cdot(5)$ & $12(73)$ & $13(15)$ & $7(7)$ \\
\hline Conper & $64(5)$ & $18(75)$ & $9(10)$ & $9(10)$ \\
\hline Glass & $90(0)$ & $3(90)$ & $0(0)$ & $7(10)$ \\
\hline Iron and Steel & $20(5)$ & $9(22)$ & $67(68)$ & 4 (b) \\
\hline $\begin{array}{l}\text { Petrochemical and } \\
\text { Chemical }\end{array}$ & $59(5)$ & $23(57)$ & $10(30)$ & $8(8)$ \\
\hline Petroleum Refining & $33(0)$ & 64 (96) & $0(0)$ & $3(4)$ \\
\hline
\end{tabular}


The detrimetnal effects of the impurities in residual oils upon refractory linings in furnaces and process heaters is clearly inhibiting wider consideration of this fuel at the present time. Potential contamination of manufactured products by residual oils is also a restricting consideration of heavy oils. Impurities present in typical bituminous coals and problems associated with fusion of the ash at temperatures above about $1150^{\circ} \mathrm{C}\left(2102^{\circ} \mathrm{F}\right)$ were also cited as major concerns that are retarding wider consideration of this alternate fuel. Fusion of the coal ash and subsequent slag deposition and reactions including fluxing, slagging, and corrosion of refractories by this fused material with combustion chamber surfaces, furnace walls, and products being heat treated plus problems with air pollution regulations and ash disposai will all tend to inhibit direct substitution of coal for natural gas in a large number of industrial furnacing applications. This present assessment identified the following industrial heating applications that involve refractories and refractory insulations and are potential areas where refractory degradation could be a major problem caused by the conversion from natural gas to heavy oil and/or coal. The various refractory applications are listed by industry:

Industry

Aluminum

Cement

Ceramics

Clıèilical

Copper

Glass

Iron and Steel

Petroleum Refining

\section{Refractory Applications}

Reverberatory melting furnaces, anode bake ovens, holding furnaces

Kilns

Kilns

Bullers, process heaters, rebollers

Reverberatory melting furnaces, converters

Glass melting furnace linings, combustion air preheating regenerators

Soaking pits, reheating furnaces, heat-treatment furnaces

Catalytic reactors

There is currently limited experimental or industrial refractory operating experience with residual oils at combustion chamber surface temperatures above about $1100^{\circ} \mathrm{C}\left(2012^{\circ} \mathrm{F}\right)$. Most available literature data on residual oils and their combustion products clearly indicate that the alkali metals, principally sodium, plus vanadium and sulfur are the primary causes of observed detrimental reactions with commonly used bulk refractories. The situation with refractory fibrous insulations is less clear, since little information is in the literature. Most of 
the available information on refractory-alternate fuel combustion product interactions has been obtained under experimental conditions that have been poor simulations of actual combustor environments and usually are more typical of classical phase equilibria work. Little quantitative information is known of the degradative reaction mechanisms, the reaction kinetics, or the dependence of either of these on temperature, combustion gas impurity composition, or oxygen potential for most of the generic classes of refractories currently used industrially. This situation is indicated for various kinds of refractories and insulations in the following table.

Current State of Information on Refractory Performance With Use of Residual Oils or Coal as Alternates to Natural Gas ${ }^{a}$

\begin{tabular}{|c|c|c|c|}
\hline & $\begin{array}{l}\text { Generic } \\
\text { Refractory } \\
\text { Type }\end{array}$ & $\begin{array}{l}\text { Pertinent } \\
\text { Phase } \\
\text { Diagrams } \\
\text { Known b }\end{array}$ & $\begin{array}{c}\text { Long-Term } \\
\text { Industrial } \\
\text { Distillate Oil } \\
\text { Firing Experience } \\
\text { Available }\end{array}$ \\
\hline 1 & Alumina & $\checkmark$ & $\checkmark$ \\
\hline 2 & $\begin{array}{l}\text { Alumina-phosphate } \\
\text { bonded }\end{array}$ & & $\checkmark$ \\
\hline 3 & $\begin{array}{l}\text { Aluminusilicate } \\
\text { (Alumina-silica) } \\
\text { (fireclays and } \\
\text { insulation fire } \\
\text { bricks) }\end{array}$ & $\checkmark$ & $\checkmark$ \\
\hline 4 & $\begin{array}{l}\text { Glass fiber } \\
\text { insulation }\end{array}$ & & \\
\hline 5 & $\begin{array}{l}\text { High-alumina } \\
\text { monolithics }\end{array}$ & & $\checkmark$ \\
\hline 6 & $\begin{array}{l}\text { Intermediate- } \\
\text { alumina } \\
\text { monolithics }\end{array}$ & & $\checkmark$ \\
\hline 7 & Magnes1a & $\checkmark$ & $\checkmark$ \\
\hline 8 & Magnesite-ohrome & $\sqrt{\prime}$ &.$^{\prime}$ \\
\hline 9 & Magnesite-silica & & $\checkmark$ \\
\hline 10 & $\begin{array}{l}\text { Oxide fiber } \\
\text { Insulations }\end{array}$ & $\checkmark$ & \\
\hline 11 & Silica & $\checkmark$ & $\checkmark$ \\
\hline 12 & Zircon & & \\
\hline
\end{tabular}


xiv

It is apparent from this table that there is a scarcity of information of the type required for industrial operational and investment planning regarding selection of refractories for use with either residual oils or coals. There is probably sufficient industrial operating experience with distillate oil combustion effects on refractories to consider this oil to be a safe and reliable substitute for naturual gas for the present. 


\section{INTRODUCTION}

The use of natural gas in the United States and the rest of the world has been increasing about $8 \%$ yearly, ${ }^{1}$ while U.S. production, declining in recent years, decreased by $5 \%$ in 1975 . Natural gas present1y supplies more than $18.5 \%$ of the world energy. The U.S. produces and consumes about $68 \%$ of the present world production; and since the early sixties, natural gas has been a primary energy source in this country. In 1970 about $35 \%$ of the U.S. energy requirements were satisfied by natural gas, ${ }^{2}$ while $46 \%$ of industrial energy needs were provided by this fuel. The purity of natural gas combustion products has been a major consideration in the industrial choice of natural gas.relevant to the present struggle against atmospheric pollution. The relatively low cost of this fuel, plus the ease in handling and combustion, have also provided a strong incentive for wide use of natural gas.

Recently in the U.S., the supply of natural gas available for industrial customers has been curtailed at various times in deference to residential customers. The number and length of these curtailments have been increasing rapidly. ${ }^{3}$

This situation has increasingly required the affected firms to provide an alternate fuel capability for their operations or to cease the operations. The alternate fuels available in the immediate term to most industrial customers are distillate oils, residual oils, coal, producer gas, and electricity. Distillate oils such as No, 2 grade are favored in the immediate term because fuel delivery and combustion: system requirements for these oils have the least incremental capital cost increase compared with natural gas; and the combustion characteristics are such that it can be used directly in much equipment in place of natural gas. Impurities in No. 2 oil tend to be low compared to those in residual oil; thus No. 2 oil offers a lower risk of equipment deterioration through detrimental chemical reactions with the fuel combustion products. Distillate oils are more expensive than residual oils. 
Residual oils require a larger incremental capital cost relative to natural gas for their use than do distillate oils; and the impurity levels are usually significantly higher in residuals. The potential of residual oils to play a major role as an alternate fuel at lower cost per unit of heat compared with distillate oils is presently hampered by concerns about possible detrimental effects some of the combustion products of residual oils may have on high-temperature industrial equipment. Much of the combustion experience in the U.S. with residual oil has been with steam boilers constructed primarily of water-cooled metal with the surface temperature limited to about $649^{\circ} \mathrm{C}\left(1200^{\circ} \mathrm{F}\right)$. At this temperature and below, corrosion rates of the boiler tubes are generally acceptable for the design life of the equipment under proper combustion conditions. For a great many industrial firing applications, temperatures well above $649^{\circ} \mathrm{C}\left(1200^{\circ} \mathrm{F}\right)$ are necessary; such operating temperatures require the use of ceramic refractories and/or refractory insulations in contact with the fuel combustion products. For these applications, relatively little specific technical information or industrial operating experience is available to aid designers in selecting refractory systems for use in conjunction with residual oil combustion. Few reports are available on the effects that residual oil combustion products have on refiactory materialo. Much more research needs to be done on this subject to provide information adequate for either equipment design or for industrial economic analyses.

Coal, propane, producer gas, and electricity are other candidate alternate fuels. Many industrial firing processes that were developed for natural gas are not readily amenable to coal conversion. Most bituminous coal slags fuse or melt at temperatures slightly above $1204^{\circ} \mathrm{C}$ $\left(2200^{\circ} \mathrm{F}\right)$; therefore a simple combustion process using coal is essentially limited to this maximum temperature in order to permit use of relatively simple ash removal systems. To use coal at higher tempratures, the reactions of coal slag with the product and with the internal parts of the firing equipment must be acceptable or controlled by means of equipment design. For many industrial firing processes this is not yet possible. The high retrofit cost for installing coal combustion 
equipment is a major negative factor in considering conversion from natural gas to coal. There is a limited industrial process combustion experience with coal in the U.S. at this time compared to three decades ago. Many of the older processes operated at lower temperatures than those now used, so the experience of the past may not necessarily be directly transferable to modern process applications. There is also a lack of documentation in this area, which can be useful in planning industrial fuel conversion to coal. Combustion emissions from most bituminous coals are above those for an equivalent heating value from No. 2 or No. 6 oil. Therefore conversion to coal rather than oil creates a potential environmental problem unless pollution control equipment is also provided. The reactions between various refractory systems and coal slags are also of strong concern in ERDA's current programs in coal gasification, recuperators, and magnetohydrodynamics. Operating experiences from this work should provide information relevant to the use of coal as an alternate industrial fuel for high-temperature applications. However, it will be some years before this data base is established and available for use in materials selection and design.

Producer gas or low Btu gas is a potential alternate fuel for natural gas and, in fact, was used industrially before the wide use of natural gas. Extensive use of producer gas appears to be hampered by present lack of producer gas supplies and the reluctance of companies to provide their own producer gas plant because of cost.

Electricity is now a serious contender as an alternate fuel or energy form for some applications. One major disadvantage is the relatively high cost of energy in this form; and secondly, much Industrial heating process equipment will require major modifications in order to use electricity.

The work described in this report was conducted over a period of three months (from February to April 1976). A selection of approximately 100 companies in energy intensive U.S. industries were contacted to determine their plans for converting to an alternate fuel, the anticipated time scale for these conversions, and their experiences with the effects that alternate fuels have on refractories and refractory 
insulations. This assessment is the first task of a program whose objectives include:

1. determination of the physical and chemical properties of alternate fuels, their combustion technologies, and their cost and availability,

2. determination of the status of present U.S. industrial planning for conversion from natural gas to alternate fuels,

3. identification of industrial process systems that will most likely experience refractory deterioration with conversion to alternate fuels,

4. review of the present knowledge of alternate fuel combustion product-combustor material reactions, and

5. studies of the mechanism of the detrimental interactions.

The emphasis of this work is on the alternate fuel situation in the immediate term that extends from the present to 1980. Through selected refractory system-alternate fuel screening tests, this program will provide a data base for refractory material design and selection. The alternate fuels will include residual oils and coals of selected compositions. Refractory types to be tested in a controlled combustion environment will include: (1) dense refractory brick, including fireclay, alumina (fused and dry-pressed fabrication), phosphate-bonded alumina, magnesia, chrome-magnesite, and silica; (2) monolithic refractoriè, including plastic mixes (ramming and gunning compositions), and castables; (3) insulating refractory bricks of various maximum temperature ratings; (4) insulating refractory fiber materials including alumina-silica based fibers, all-alumina fibers, all zirconia fibers, and refractory fiber bat support structures, and (5) refractory mortars for dense refractory brick structures. After selected exposure times to alternate fuel combustion, the refractories or refractory insulations will be characterized in terms of changes in microstructure, phase content, chemical composition, and mechanical properties. The interpretation of the results from the screening tests will be based on the thermochemical and thermomechanical analyses described in this report along with the limited available industrial observations of. these systems. The results of the screening tests will be used to provide parametric descriptions of the sensitivity 
of various industrial refractories and refractory insulations to conversions to these alternate fuels.

Large-scale field tests that involve industrial furnacing operations using alternate fuels will possibly be conducted in cooperation with industrial firms and ERDA. Presumably, the results of these tests would provide confirmation of the results obtained in our smaller scale combustor evaluations and thereby accelerate industrial acceptance of the results.

\section{REFERENCES}

1. M. Medic1, The Natural Gas Industry, p. 35, Butterworth and Co., Ltd., London, 1974.

2. A. F. Bass, "Curtailments of Natural Gas Service," Monthly Energy Review, NTISUB/B/127-76/001, pp. 2-13 (January 1976).

3. "Certain Background Information for Consideration When Evaluating the National Energy Dilemma," Joint Committee on Atomic Energy, U.S. Government Printing office, No. 5270-01801 (1973). 


\section{THIS PAGE}

\section{WAS INTENTIONALLY \\ LEFT BLANK}




\section{CONCLUSIONS AND RECOMMENDATIONS}

\subsection{CONCLUSIONS}

This assessment indicates that, in the immediate term, there is a large amount of activity toward conversion away from natural gas in a variety of industries because of the scarcity of this fuel. Refractories and refractory insulations that are used in industrial furnace heating applications and that are likely to be affected in the near term by the impurities in the alternate fuels were identifled. The interactions of the combustion ash, slag, and vapor with the refractory material that lead to refractory degradation were analyzed. Successful conversion to alternate fuels requires proper selection and design of the refractory systems. The conclusions are itemized as follows.

1. Due to the lifetime of combustion equipment and furnaces, the decisions on fuel conversion and refractory material selection made now will have an effect in the long term (1985-2000 period). This should be considered in any long-range planning. There is also a need for establishing a long time data base of alternate fuel combustion.

2. The alternate fuel for most industries in the immediate term is fuel oil, including both No. 2 and No. 6 grades.

3. The increase in the oil demand is expected to be matched by increased imports:

4. Coal combustion systems typically involve large capital investments relative to oil systems. Large industrial boilers ( $>25 \mathrm{MW}$ ) generally are planned 1nitlally for coal and can be converted to burn coal if they have been used for oil or gas. Medium and small boilers are more economically converted to residual or distillate oils. The cement industries and those parts of the ceramic industry using relatively 1ow-temperature firing $\left[<1093^{\circ} \mathrm{C}\left(2000^{\circ} \mathrm{F}\right)\right]$ are converting from natural gas to coal.

5. The vanadium, sodium, and sulfur that are the major impurities in both residual and distillate oils can cause fluxing, spalling, and cracking in aluminosilicate, magnesite-chrome, and zircon refractories used in brick and monolithic forms. These reactions are dependent upon 
the combustion conditions. The impurity content in fuel oils varies widely, depending on the crude source, storage, and shipping conditions.

6. Refractory mortars usually contain a high percentage of calcium aluminate cement that is readily attacked,by the vanadium and sodium in residual and distillate oils. Higher alumina, lower calcium oxide content, and higher density in mortars can give better resistance to fuel impurity attack.

7. Aluminosilicate refractories resist vanadium attack, but are readily corroded by sodium-containing solids, melts, and vapors at certain temperatures. The magnesite-chrome refractory system resists sodium attack, but is seriously fluxed by vanadium-containing solids, melts, and vapors. Therefore, in the presence of both vanadium and sodium, these two widely used industrial refractory systems will be degraded. Sulfur in heavy oils and coals generally attacks the refractory materials and tends: to cause extensive deterioration in refractories and refractory insulations. Higher alumina or magnesia content, low alkali content, less glass phase; low calcium oxide content, and low porosity are essential factors for increased refractory resistance to attack by vanadium and sodium ash, slag, and vapor species.

8. Silicon carbide and $\mathrm{Si}_{3} \mathrm{~N}_{4}$ reportedly resist fuel oil ash corrosion better than many other refractories. However, the high thermal conductivities of these materials requires 1ncreasing both the quality and the thickness of the backup insulation if these materials are used as the furnace hot face.

9. Some chemical and petrochemical companies are planning to make extensive conversions soon from natural gas in boilers and process heaters to No. 6 oil and No. 2 oil, respectively. Fireclay refractories, which are generally used in some of these builers and particularly in process heaters, are subject to combustion ash corrosion at temperatures above about $800^{\circ} \mathrm{C}\left(1472^{\circ} \mathrm{F}\right)$.

10. The aluminum industry, is converting to No. 2 and No. 6 oils in remelting and reheating furnaces that were built of high alumina $\left(>70 \% \mathrm{Al}_{2} \mathrm{O}_{3}\right)$ or phosphate bonded alumina refractories. The use of 
No. 6 oil requires higher alumina content in the aluminosilicate refractory system. Anode bake ovens built of fireclay bricks probably will have to be upgraded to higher alumina content bricks before conversion to No. 6 oil.

11. Some steel companies are concerned about the contamination of their products by the impurities in the alternate fuels such as No. 6 oil or coal. In some plants, coke oven capacity is planned to be expanded for supplying coke oven gas to replace natural gas in soaking pits, heating and reheating furnaces. Nonintegrated companies that do not have coke ovens are converting to No. 6 and No. 2 oils. The refractories used in these furnaces cover a broad range of compositions and, in general, must be of high alumina or magnesia content, low porosity, and low alkali content for applications involving No. 6 oil.

12. Some of the glass companies are considering No. 2 oil for immediate-term conversion because of concern about detrimental reactions with No. 6 oil in their checkerwork brick in the furnace regenerators used to preheat the combustion air. Basic refractories that best resist the combustion ash attack are of high magnesium oxide content, direct bonded or forsterite bonded, low $\mathrm{CaO} / \mathrm{SiO}_{2}$ ratio, magnesite-chrome bricks. Some glass companies are seriously considering converting to electric melting.

13. The copper industry is converting to distillate and residual oils in their remelting furnaces and converters. Residual oil combustion requires the use of higher-purity materials in the basic refractories used for the side wa11s and the aluminosilicate refractories used in in the roof.

14. Some refractory companies are converting to No. 2 oil because of concern about detrimental reactions that can occur in their kilns and products with the use of residual oils at the relatively high firing temperatures required.

15. Published information un alternate fuel combustion product (solid deposit,:slag, liquid, and vapor) attack in refractory materials is sparse. There are few Industrial observations from which detailed data could be extracted for this assessment. In some cases, the 
information was regarded as proprietary. In most others, there was either no operational experience or the limited amount available was not amenable to interpretation. A systematic test program exposing generic types of refractory materials to alternate fuel combustion under controlled conditions of combustion time, mean temperature, temperature gradient, temperature cycling, and oxygen potential would provide guidelines to the sensitivity of various industrial refractory materials to alternate fuel combustion product attack. Large scale field test projects will help establish the magnitude of refractory deteriorations in various industrial furnacing applications under fullscale conditions.

16. The physical and chemical properties (e.g., density and standard free energy of formation) of certain phases (e.g., nepheline, $\beta$-alumina) resulting from combustion product attack of some refractories are still unknown and should be determined. Phase equilibrium and diffusion data in systems experiencing fuel ash attack (such as $\mathrm{V}_{2} \mathrm{O}_{5}-\mathrm{Na}_{2} \mathrm{O}-\mathrm{SO}_{3}-\mathrm{AJ}_{2} \mathrm{O}_{3}-\mathrm{SiO}_{2}$, $\mathrm{V}_{2} \mathrm{O}_{5}-\mathrm{Na}_{2} \mathrm{O}-\mathrm{SO}_{3}-\mathrm{MgO}-\mathrm{Cr}_{2} \mathrm{O}_{3}$ ) are extremely limited and, in some cases, even contradictory. Additional experimental work is needed in determining these parameters as they are required in the thermochemical and thermomechanical prediction and analysis that are essential to understanding refractory degradation mechanisms. This type of information is essential to developing refractory materials that resist attack from the combustion products of alternate fuels.

\subsection{RECOMMENDATIONS FOR SELECTION OF REFRACTORIES FOR USE WITH ALTERNATE FUELS}

Based on the assessment of industrial fuel conversion and the analysis of refractory deterioration due to interactions with combustion products, such as those containing vanadium, alkalies, and sulfur; future work is needed to better define phase relations and kinetic data for the fuel impurity and refractory material interactions. The thermochemical and thermomechanical parameters of the reaction products should also be determined. A laboratory test program and a field test program that covers a broad range of refractory and insulating materials 
used in various combustion conditions for long times under high temperature test conditions are needed.

Six recommendations for selection of the presently available refractories for use with alternate fuels are:

1. Silica refractories should be replaced by other types of refractories that better resist combustion ash attack; since at temperatures above $1500^{\circ} \mathrm{C}\left(2732^{\circ} \mathrm{F}\right)$, silica bricks are seriously fluxed and cracked by sodium present in the combustion products of fuel oil.

2. The aluminosilicate materials in systems subject to the fuel conversion should be upgraded to higher alumina content, lower porosity, minimum glass phase, and low alkali content.

3. Phosphate-bonded alumina probably should not be used in alkaliand vanadium-rich environments characteristic of combustion of some residual oils.

4. Since plastic and castable refractories that contain calciumoxide-based cements react with fuel oil ash, the use of these mixes should be carefully studied and attention directed to lowering the calcium-oxide content, lowering the glassy-phase content, and increasing the $\mathrm{Al}_{2} \mathrm{O}_{3}$ content.

5. The basic refractories, which are seriously fluxed by vanadium, should be upgraded by increasing the magnesium oxide content. Direct bonded, or forsterite bonded, low $\mathrm{CaO} / \mathrm{SiO}_{2}$ ratio, basic refractories are preferied.

6. The applications of zircon refractories probably should be linited to temperature 10 wer than $1000^{\circ} \mathrm{C}\left(1832^{\circ} \mathrm{F}\right)$ at which decompostion will start in the presence of residual oil fuel ash components. 


\section{THIS PAGE}

\section{WAS INTENTIONALLY LEFT BLANK}




\section{ALTERNATE FUELS FOR THE IMMEDIATE TERM (1976-1980)}

The total energy consumption in U:S. industries was about $29 \%$ of the total energy supply in the whole nation $\left(73.1 \times 10^{15} \mathrm{Btu}\right)$ in $1974 .^{1}$ About $54 \%$ of the energy sources for industrial heating and power applications in 1971 (Table 3.1) was natural gas. ${ }^{2}$ Industry's reliance on natural gas is evident. Natural gas is used to such an extensive degree that a wide variety of industries are dependent on it. For example, chemical and petrochemical, primary metal (steel and aluminum), copper, glass, cement, refractory, food, and paper industries have been using natural gas as a principal fuel to heat their.furnaces, boilers, kilns, and reactors. Due to federal regulations, the price increase of natural gas in recent years (Fig. 3.1) is only moderate as compared to those of fuel oils and coal, even though the demand for natural gas from industry and residential customers has always been increasing. ${ }^{3}$ Clean, low priced, and relatively easy to handle, transport, and store, natural gas is far superior to other types of fuel.

\section{Table:3.1. Distribution of Energy Sources in Industrial Heating and Power Applications in 1971}

\begin{tabular}{lc}
\hline \multicolumn{1}{c}{ Fuel } & $\%$ \\
\hline Natural gas & 53.9 \\
Electricity & 14.2 \\
Fuel oil & 12.1 \\
Coal & 13.0 \\
Other & 6.8 \\
\hline \multicolumn{2}{c}{ Source: 1972. Census of Manufac- } \\
turers, p. 6-197, I.S. Census Bureau, \\
Washington, D.C.
\end{tabular}

However, the production of natural gas, following an abrupt leveling off since 1970, experienced the first significant decline in 197.4 despite the 7.240. new producing wells completed in that year that represented the greatest number of new producing wells in the history of the natural gas 


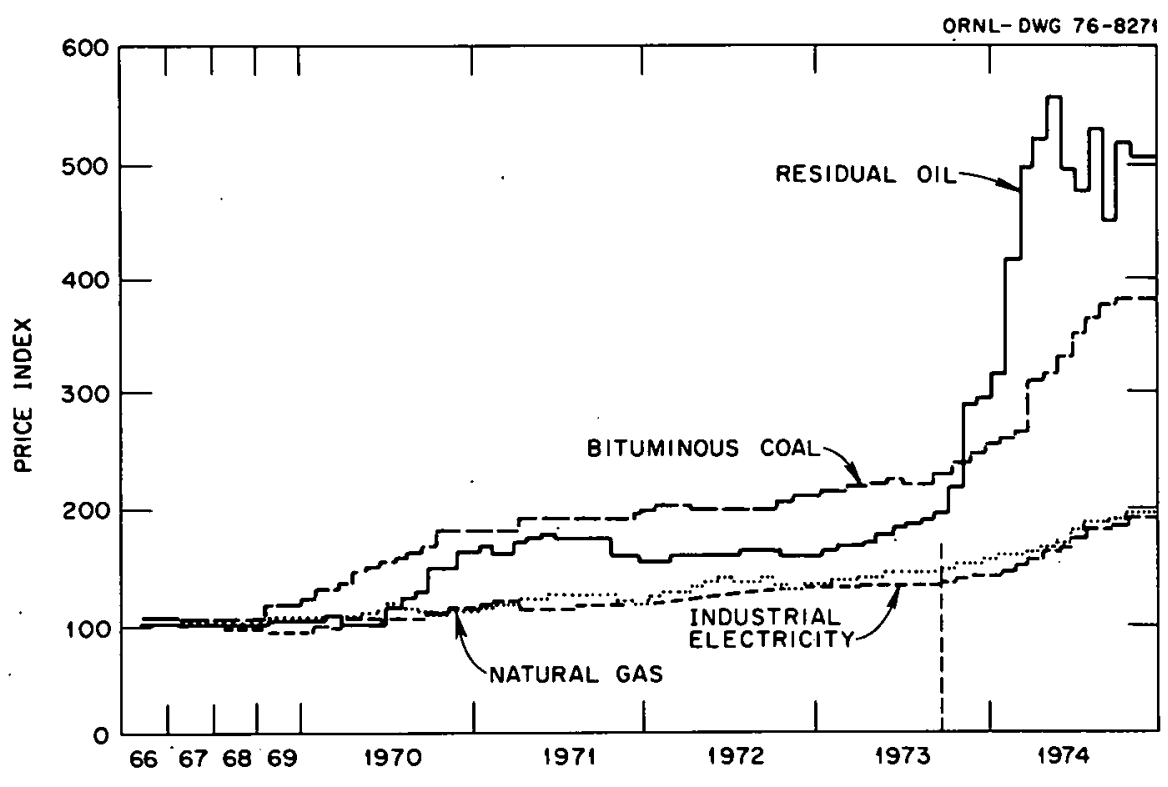

Fig. 3.1. Relative Increase of the Price Index for Fuels and Electricity (Price Index $1967=100$ ). Reprinted with permission from G. C. Gambs, "The Case for Energy Management," in The 1975 Energy Management Guidebook, ed. by the editors of Power Magazine, McGraw-Hill, New York, 1975.

industry. ${ }^{4}$ The continuous shortage of natural gas (Table 3.2) will be as much as $12.2 \times 10^{15} \mathrm{Btu}$ by 1980 and has already resulted in serious curtailment to industrial users. ${ }^{5}$ In 1976 alone, the curtailment of natural gas in interstate pipelines may amount to nearly $2 \times 10^{12} \mathrm{ft}^{3} .^{5}$ Such a shortage will have a serious and immediate impact on industries and electric power utilities. Industrial users get only short notice (one day to one month) that their gas supply is being reduced. Many industries facing the natural gas shortage, which is by no means shortterm, are therefore converting their furnaces to other available fuels in order to keep their production constant. The principal reason for these conversions is not the cost of natural gas, but rather its shortage.

Alternate fuels such as distillate oils, residual oils, coal, and low-Btu gases, and other energy sources such as electricity, have been considered as replacements for natural gas. However, the use of these fuels requires an understanding of their physical and chemical characteristics as well as the installation of new fuel storage, piping, and combustion equipment that are usually capital intensive. The selection 
Table 3.2. Comparison of Natural Gas Supply and Demand $\left(\text { Btu } \times 10^{12}\right)^{a}$

\begin{tabular}{lccc}
\hline & 1975 & 1980 & 1985 \\
\hline Potential demand & 30,268 & 34,700 & 40,119 \\
Anticipated supply & 22,420 & 22,480 & 22,180 \\
Indicated shortfal1. & 7,848 & 12,220 & 17,939 \\
\hline \multicolumn{2}{c}{ a Source: U.S. Energy OutZook - Gas Demand, p. 4, } \\
National Petroleum Council, Washington, D.C., 1973.
\end{tabular}

of the most suitable alternate fuel depends on its economics in terms of fuel cost, availability, and necessary capital investment, and the influence of fuel conversion on product quality and production rate. In addition, the direct impact of. fuel conversion on the refractories and refractory insulation in furnaces has to be evaluated. An incorrect choice of the refractory materials can easily cost millions of dollars in repairs for a large installation, not including production losses because of downtime. The successful use of an alternate fuel thus hinges critically on the selection of a refractory based on an understanding of its interaction with the combustion products which, in turn, depends upon the physical and chemical properties and flame characteristics of the fuel to be used.

\subsection{DISTILLATE OILS}

Distillate oils have been used in many industrial heating installations and are considerd one of the most ideal fuels to substitute for natural gas. There are two classes of distillates: namely, straightrun and cracked. Commercial distillate oils are usually mixtures of these two. A straight-run oil is distilled directly from crude oil while a cracked oil is produced from heavier fractions at high temperatures and pressures. The difference between these two types of oil is that cracked distillates contain a substantial amount of heavy hydrocarbons, which are more difficult to burn than the light hydrocarbons in the straight-run distillates. There are two commercial grades of distillate oils: namely, No. 1 and No. 2 (Table 3.3). 
Table 3.3. Standards for Distillate and Residual 0ils, D-396 ${ }^{2}$

\begin{tabular}{|c|c|c|c|c|c|c|c|c|c|c|c|c|c|c|c|}
\hline \multirow{3}{*}{ Grade } & \multirow{3}{*}{$\begin{array}{c}\text { Flash } \\
\text { Point } \\
\left({ }^{\circ} \mathrm{F}\right)\end{array}$} & \multirow{3}{*}{$\begin{array}{r}\text { Pour } \\
\text { Point } \\
\left({ }^{\circ} \mathrm{F}\right)\end{array}$} & \multirow{3}{*}{$\begin{array}{c}\text { Water } \\
\text { and } \\
\text { Sediment } \\
\text { (vol \%) }\end{array}$} & \multirow{3}{*}{$\begin{array}{c}\text { Maximum } \\
\text { Ash } \\
\text { (wt \%) }\end{array}$} & \multirow{3}{*}{$\begin{array}{c}\text { Carbon } \\
\text { Residdse } \\
\text { on } 10 \% \\
\text { Bottoms } \\
(\%)\end{array}$} & \multicolumn{4}{|c|}{ Saybolt Viscosity $(\mathrm{sec})^{\mathrm{b}}$} & \multicolumn{4}{|c|}{ Kinematic Viscosity $(c S t)^{b}$} & \multirow{3}{*}{$\begin{array}{l}\text { Minimuu } \\
\text { Gravity } \\
\text { (deg API) }\end{array}$} & \multirow{3}{*}{$\underset{(\%)}{\text { Sulfur }}$} \\
\hline & & & & & & \multicolumn{2}{|c|}{ Universal at $100^{\circ} \mathrm{F}$} & \multicolumn{2}{|c|}{ Furol at $122^{\circ} \mathrm{F}$} & \multicolumn{2}{|c|}{ at $100^{\circ} \mathrm{F}$} & \multicolumn{2}{|c|}{ at $122^{\circ} \mathrm{F}$} & & \\
\hline & & & & & & $\min$ & $\max$ & min & $\max$ & $\min$ & $\max$ & $\min$ & $\max$ & & \\
\hline 1 & $100^{c}$ & od & Trace & & 0.15 & & & & & 1.4 & 2.2 & & & 35 & $0.5^{\mathrm{c}}$ \\
\hline 2 & $100^{c}$ & $20^{d}$ & 0.05 & & 0.35 & $(32.6)$ & $(37.9)$ & & & $2.0^{\mathrm{d}}$ & 3.6 & & & 30 & $0.5^{c,}$ \\
\hline 4 & $130^{\mathrm{c}}$ & $20^{d}$ & 0.5 & 0.1 & & 45 & 125 & & & $(5.8)$ & $(26.4)^{\mathrm{f}}$ & & & & Legal \\
\hline 5 Heavy & $130^{\mathrm{c}}$ & & ]. & 0.1 & & 350 & 750 & (23) & $(40)$ & (75) & $(162)^{f}$ & $(42)$ & $(81)$ & & Legal \\
\hline 6 & 150 & $\mathbf{f}$ & $2^{h}$ & & & $(900)$ & $(9000)$ & 45 & 300 & & & (92) & $(638)^{\mathrm{f}}$ & & Legal \\
\hline
\end{tabular}

asource: "Petroleum Products and Lubricants," part' 23, pp. 219-20, 1975 Annual Book of ASTM Standards, D56-D1660, American Society for Testing and Materials, Philadelphia.

biscosity values in parentheses are for information only and not necessarily limiting.

cstatute value.

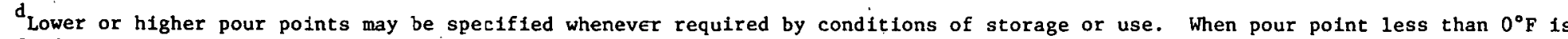
specified, the minimum viscosity for Grade No. 2 shall be $1.8 \mathrm{cSt}(32.0-\mathrm{S}$ Saybolt Universal).

eIn foreign countries, other sulfur limits may apply.

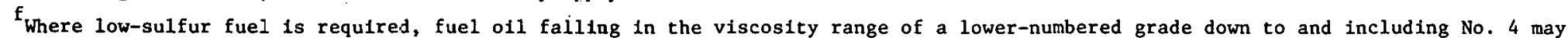
be supplied by agreement between purchaser and supplier: The viscosity range of the initfal shipment shall be identified, and advance notice shall be required when changing from one viscosity range to another. This notice shall be in sufficient time to permit the user to make the necessary adjustments.

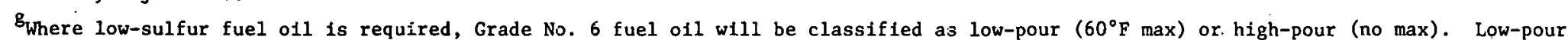
fuel oil should be used unless all tanks and lines are hected.

' $h$ The amount of water by distillation plus the sedimert by extraction shall not exceed $2 \%$. The amount of sediment by extraction shall not exceed $0.5 \%$. A deduction in quantity shall be made fcr all water and sediment in excess of $1 \%$. 
Number 1 oil is widely used for space heating. Number 2 oil is widely used in many industrial combustion installations such as melting furnaces, heat and reheating furnaces, kilns, glass tanks, packaged boilers, incinerators, and process heaters.

Distillate oils are relatively easy to handle, store, and burn as compared to residual oils and coal. They have good pumping properties and can be pressure atomized by air, steam, or ultrasonics. The maximum amount of sulfur is typically specified as 0.3 wt \% for distillates.

The American Society for Testing and Materials has developed several standard test methods and procedures for determining the quality of fuel oils according to physical properties such as specific gravity, heating value, viscosity, water and sediment, and pour, flash, and fire points, all of which are important to handling and combustion. The heating value of No. 2 distillate oil varies with the gravity and the sulfur content, and is typically $142,000 \mathrm{Btu} / \mathrm{gal}$. The gravity scale used in the petroleum industry is the American Petroleum Institute (API) scale and not the specific gravity of the oil. Number 1 oil has an API gravity range of 41 to 46 degrees; No.' 2 oil, 30-39. Viscosity is an important factor in the design of the efficiency and sizing of pumps, pumping temperature, and pipeline sizing. Viscosity is the time in seconds that it takes $60 \mathrm{~cm}^{3}$ of oil to flow through a standard size orifice at standard temperature. The Saybolt Furol and Universal viscosimeters are generally used. The pour point of an oil is the lowest temperature at which it flows under standard conditions. Distillate oils usually pour freely above $-12^{\circ} \mathrm{C}\left(10^{\circ} \mathrm{F}\right)$. Flash point is the temperature at which oil vapors flash when ignited and is a measure of the volatility of the oil. Distillate oils normally have flash points from 62 to $93^{\circ} \mathrm{C}\left(145\right.$ to $\left.200^{\circ} \mathrm{F}\right)$. The total amount of water and sediment in distillate oils can be $0.2 \%$ of total volume: Water can lead to corrosion of storage tanks and piping and can cause inefficient combustion. Distillate oil generally contains impurities other than sulfur at levels < $1 \mathrm{ppm}$. Depending on the crude source, handling, shipping, and storage conditions, impurities may include some sodium in the form of salt water and some lead from contamination by lead-bearing 
gasoline. As many as 25 different metals can be found in distillate oils. Vanadium, sodium, iron, nickel, calcium, and aluminum are the most prevalent. A chemical analysis normally is not included in a distillate oil specification, except for the sulfur content. As a matter of fact, many oil companies are reluctant to release this kind of information. The metallic elements in oil are in the form of organometallic compounds that are extremely difficult to remove. Data from two oil companies (Table 3.4) indicate typical metallic impurity contents. Since low-level impurities in distillate oils are difficult to quantitatively determine, there is a continuing effort to develop more exact analytical methods.

The ash content of distillate oils is about $<0.1 \%$. Although the percentage is low, a considerable amount of ash could accumulate during the life of the unit if the solids and some of the gaseous species react and remain in the combustion chamber. The fuel ash of distillate oils is composed of hydrocarbons, oxygen, nitrogen, sulfur, chlorine, and organometallic compounds. Beside reducing the heat transfer efficiency, ash deposits can also cause corrosion, cracking, spalling, and fluxing in the metals or ceramics in the combustion chamber. On the other hand, distillate oil combustion is similar to that of natural gas in flame length, flame geometry, and temperature range.

The availability of distillate oils is related to the crude oil supply and the demand for higher grade petroleum products such as gasoline and diesel fuel. The statistics of the American Petroleum Institute show that in 1974 about 10\% of distillate fuel oil was apparently imported. ${ }^{6}$ If the imported crude oil that was later refined into distillates were included, the total import accounted for about $40 \%$ of the total supply of distillate oils $(2,951,000$ barrels per day). As industrial needs increase, the supply of distillate oil will rely heavily on imports in the immediate term. The average price of No. 2 oil in 1974 was $\$ 2.59$ per million $\mathrm{Btu}$, or equivalently, $\$ 10.50$ per barrel. ${ }^{4}$ The price increase was nearly $70 \%$ in one year alone. It is expected that by 1980 industry will pay $\$ 25$ per barrel for fuel oils. ${ }^{3}$ 
Table 3.4. Typical Metallic Impurities and Sulfur Content (ppm) ${ }^{a}$ in Distillate and Residual Oils from Two Oil Companies

\begin{tabular}{|c|c|c|c|}
\hline \multirow[t]{2}{*}{ Impurity } & \multicolumn{2}{|c|}{ From Company A } & \multirow{2}{*}{$\frac{\text { From Company B }}{\text { No. } 20 i 1}$} \\
\hline & No. 1 Oil & No. 2 0il & \\
\hline Sulfur & $350-1,500$ & $1.200-2,500$ & 0.3 wt $\%$ \\
\hline Sodium & $0.01-0.1$ & $0.02-0.2$ & $0.05-0.13$ \\
\hline Lead & $0: 01-1.0$ & $0.01-1.0$ & $<0.10$ \\
\hline Vanadium & $0.01-0.5$ & $0.01-0.5$ & $<0.05$ \\
\hline Copper & $0.005-0.05$ & $0.005-0.05$ & \\
\hline Caicium & $0.01-0.1$ & $0.01-0.15$ & $<0.002$ \\
\hline \multirow[t]{2}{*}{ Potassium } & $0.01-0.06$ & $0.01-0.10$ & \\
\hline & No. 4 oil (Low Sulfur) & No. $60 i l$ (Low Sulfur) & No. 6 oil (Domestic) \\
\hline Sulfur & $5,000-10,000$ & $5,000-10,000$ & 2.9 wt $\%$ \\
\hline Vanadium & $1-65$ & . $12-100$ & 50 \\
\hline Nickel & $1-65$ & $15-100$ & 15 \\
\hline Iron & $1-20$ & $20-40$ & 10 \\
\hline Sodium & $1-25$ & $25-50$ & 4 \\
\hline \multirow[t]{2}{*}{ Calcium } & $1-20$ & $10-50$ & 2 \\
\hline & No. 4 Oil (High Sulfur) & No. 6 oil (High Sulfur) & No. 6 Oil $^{\mathrm{b}}$ \\
\hline Sulfur & $15,000-30,000$ & $15,000-30,000$ & 2.9 wt $\%$ \\
\hline Vanadium & $30-100$ & $30-200$ & 350 \\
\hline Nickel & $15-100$ & $15-100$ & 25 \\
\hline Iron & $5-50$ & $5-50$ & 115 \\
\hline Sodium & $5-50$ & $15-75$ & 5 \\
\hline Calcium & $5-50$ & $15-75$ & 5 \\
\hline
\end{tabular}

${ }^{a}$ Unit of impurity content is ppm unless noted.

${ }^{b}$ From Caribbean crude containing vanadium below $500 \mathrm{ppm}$. Vanadium content of one Venezuelan crude can be as high as $1200 \mathrm{ppm}$. 
The supply of distillate oils depends on international markets and a stable supply in the future is very questionable. In addition, No. 2 oil is expensive (about $\$ 2.59$ per million Btu vs $\$ 0.68$ per million Btu for natural gas), ${ }^{4}$ and sizable capital investments are necessary for combustion, storage, and piping equipment. Nevertheless, industrial users facing the severe curtailment of natural gas still consider distillate oils, especially No. 2, an ideal alternate fuel provided the refractory materials in furnaces and combustion chambers are selected proper1y.

\subsection{RESIDUAL OILS}

Residual oils are also promising alternate fuels. There are three grades of residual oils: Numbers 4,5 , and 6 . Of these three, No. 6 or Bunker $\mathrm{C}$ is most widely used by industry. Basically, No. 6 oil is the residue left after most of the light volatile products have been distilled from the crude oil. Today's residual oils are usually blends of distillates and heavy residuals. The production of No. 6 oil historically has not been determined by its demand, but rather the demand for gasoline and distillates. However, the high market price of residual oils has encouraged some refiners to increase the production of residual at the expense of light distillates. The price index for residual oil doubled from 1970 to $1973 .^{3}$ Coal prices also increased significantly. In comparison, natural gas and industrial electricity only showed modest price increases. In 1974, the price of residual oil was $\$ 2.05$ per million Btu, or equivalently, \$13.09 per barrel. Most recently, No. 6 oil prices have been increased to nearly equal that of No. 2 oil. Numbers 4 and 5 oil can be produced by blending from 20 to $85 \%$ of No. 2 oil with No. 6 oil to meet ASTM specifications, or it can be a straight-run product. Number 5 oil comes in two classes. Light No. 5 oil can be atomized while heavy No. 5 oil needs preheating. Separation of two components in the storage tank can cause blended residual oil to become an unstable fuel. If the storage tank system is properly designed so that the oil is conditioned by heating, agitation, and thermal insulation, the blended fuel oil should not separate. 
In 1974 the total U.S. residual oil demand was 2,655,000 barrels per day, of which $73 \%$ was imported. The availability of residual oils is thus more dependent on foreign sources than light distillates. While it could be a good alternate fuel in the immediate term, its long-term supply could easily be interrupted by international market turmoil or instability.

The heating value of residual oil is typically 152,000 Btu/gal. The range of viscosities for residual oil is quite broad (Table 3.3). Its pour point usually ranges from -4 to $18^{\circ} \mathrm{C}\left(25\right.$ to $\left.65^{\circ} \mathrm{F}\right)$. Normal heating of storage tanks, pipelines, and pumping equipment keeps the oil well above this range of temperatures. The flash point of heavy oil can be as high as $121^{\circ} \mathrm{C}\left(250^{\circ} \mathrm{F}\right)$. The amount of water and sediment in residual oil is from 0.1 to $2 \%$. Sulfur content is generally at the level of $3 \mathrm{wt} \%$, but the limit specified for a given application is that which is dictated by the local environmental regulations. The ash content in residual oil ranges from 0.2 to $1.5 \%$. Vanadium, sodium, iron, nickel, lead, calcium, and aluminum are generally present at levels higher than a few ppm in most residual oils. Vanadium is present in sma11 amounts in most U.S. domestic crudes, but may appear in substantial quantities in Venezuelan or Arabian crudes (Table 3.4) and, in some cases, can be as high as $2000 \mathrm{ppm}$ (0.2\%).

The difference in the impurity level among these oils can be an order of magnitude or more. For this assessment, oil companies were reluctant to release impurity specifications for their No. 6 oils. The general opinion expressed by oil chemists during this assessment is that the range of the properties of residual oil such as impurity content and viscosity will continue to be broad in the immediate future. It is generally agreed that no specification can presently be written such that the burning qualities of fuel oil are reproducible. Englneers therefore must consider accommodations for a wide range of properties in designing combustion, pumping, piping, and storage systems.

Experiences of combustion equipment builders indicate that, in general, the larger the size of the heavy oil burner, the better it works above a level of about 1.5 million Btu/hr. Efficient high velocity 
light oil burners have been commercially available for some time. However, development of a high velocity heavy oil burner capable of low excess air firing without formation of carbon deposits in the burner tile is still unsuccessful. ${ }^{7}$

One of the inevitable results of the high metallic impurity content in residual oil is the deterioration in refractory materials in the combustion space. In addition to the sizable increased amount of maintenance work, the problems associated with conversion to residual oil firing are: (1). the flame temperature usually is higher than that of natural gas, (2) the flame length is longer than in the case of natural gas and is likely to impinge on the products and furnace walls, which were formerly at a distance from the flame, (3) the high level of contaminants in combustion products and in the exhaust gas often causes air pollution violations, and (4) the combustion products corrode, flux, and crack the refractory materials in the furnace and generate thick deposits in the cooler places in the furnace. These installations also require more capital investment than those using distillate oils. Despite these potential disadvantages, industrial heating apparatus in which very high temperatures $\left[>1482^{\circ} \mathrm{C}\left(2700^{\circ} \mathrm{F}\right)\right]$ will not be used is being converted to heavy oils because the product contamination can be tolerated. Since residual oils are expected to be more readily available to industrial customers than distillate oil in the immediate term (1976-1980), respondents indicated that residual oil is expected to be a principal alternate fuel in the next five to ten years.

\subsection{COAL}

Coal is the most economical source of energy for many industrial heating applications. Identified and projected reserves of coal in the U.S. amount to 3224 billion tons, which is more than half of the world total reserves. ${ }^{8}$ About $5 \%$ of the total U.S. reserves are economically recoverable at this time. In 1970 the total U.S. coal demand was about 613 million tons. About $50 \%$ of this amount was used for electrical power generation and $34 \%$ was used in industrial heating and coking. The average price of coal in 1974 was $\$ 18$ per ton or 
equivalently $\$ 0.89$ per million Btu. ${ }^{3}$ by 1980 it is predicted that coal prices will be close to $\$ 50$ per ton. ${ }^{3}$

The properties of coal vary greatly among different sources. For example, high sulfur Eastern bituminous and low sulfur Western subbituminous and lignite are very different in moisture content, ash content, ash-fusion temperature, sulfur content, alkali content, etc. The successful use of coal as an alternate fuel therefore depends on the careful evaluation of the performance of a particular type of coal in a particular furnace. Bituminous coal contains 1 to $5 \%$ moisture, whereas some Western lignites contain up to $45 \%$ moisture. Coal ash composition also varies widely. For example, Eastern coal ash has a greater percentage of ferric oxide than calcium oxide and magnesium oxide, while for Western coals the reverse is true. Ash contents of coals can vary from 3 to $30 \%$ (Table 3.5). Sulfur in coal is in the form of pyrite, marcasite, calcium sulfate, or organic sulfur, and ranges from trace quantities to almost $8 \%$. The heating value of bituminous coal varies with those physical and chemical properties and is generally about $24,000,000$ to $28,000,000 \mathrm{Btu} / \mathrm{ton}$. Lignites have heating rates of $6,000,000$ to $10,000,000 \mathrm{Btu} / \mathrm{ton}$.

Pulverized coal, which is ground from the raw coal, is often used in industrial heating and steam generation. But the high capital cost of the necessary installations such as combustion equipment, storage, grinding, moisture treatment, flue gas cleaning, and transportation generally amounts to about triple the cost of an equivalent distillate fuel oil firing unit. This is a big obstacle to the wide use of coal as an alternate fuel. The high percentage of noncombustible materials in coal will lead to ash deposits in the furnace with the consequence of reduction in furnace efficiency and possible violations of local environmental regulations. Problems such as clinkering, corrosion, and slagging in a coal-fired furnace dictate that the temperature should be kept below approximately $1093^{\circ} \mathrm{C}\left(2000^{\circ} \mathrm{F}\right)$. In some cases, the refractory material in the combustion chamber or burner must be upgraded via compositional changes to be suitable for a specific type of coal. Despite these limitations and the high capital investment, 
Table 3.5. Examples of Ash Composition in a Typical West Virginia Coal and a Montana Coal

\begin{tabular}{|c|c|c|c|c|c|}
\hline Oxide & $\begin{array}{c}\text { Average } \\
\text { wt } \%\end{array}$ & Oxide & $\begin{array}{c}\text { Average } \\
\text { wt } \%\end{array}$ & Oxide & $\begin{array}{c}\text { Average } \\
\text { wt } \%\end{array}$ \\
\hline \multicolumn{6}{|c|}{ West Virginia Bituminous Coal Ash $^{\mathrm{a}}$} \\
\hline $\mathrm{Li}_{2} \mathrm{O}$ & 0.075 & $\mathrm{Ag}_{2} \mathrm{O}$ & 0.0010 & $\mathrm{La}_{2} \mathrm{O}_{3}$ & 0.030 \\
\hline $\mathrm{Na}_{2} \mathrm{O}$ & 1.78 & $\mathrm{As}_{2} \mathrm{O}_{3}$ & $<0.07$ & Mno & 0.046 \\
\hline $\mathrm{K}_{2} \mathrm{O}$ & 1.60 & $\mathrm{~B}_{2} \mathrm{O}_{3}$ & 0.12 & $\mathrm{MoO}_{3}$ & 0.016 \\
\hline $\mathrm{Rb}_{2} \mathrm{O}$ & 0.030 & $\mathrm{BeO}$ & 0.008 & NiO & 0.047 \\
\hline $\mathrm{CaO}$ & 2.76 & $\mathrm{Bi}_{2} \mathrm{O}_{3}$ & $<0.004$ & $\mathrm{P}_{2} \mathrm{O}_{5}$ & 0.35 \\
\hline Sro & 0.38 & $\mathrm{Cb}_{2} \mathrm{O}_{5}$ & 0.010 & $\mathrm{Pbo}$ & 0.048 \\
\hline $\mathrm{BaO}$ & 0.22 & $\mathrm{CoO}$ & 0.010 & $\mathrm{Sb}_{2} \mathrm{O}_{3}$ & $<0.005$ \\
\hline $\mathrm{MgO}$ & 0.98 & $\mathrm{Cr}_{2} \mathrm{O}_{3}$ & 0.023 & $\mathrm{SnO}_{2}$ & 0.020 \\
\hline $\mathrm{Al}_{2} \mathrm{O}_{3}$ & 29.9 & $\mathrm{CuO}$ & 0.061 & $\mathrm{~V}_{2} \mathrm{O}_{5}$ & 0.050 \\
\hline $\mathrm{SiO}_{2}$ & 43.9 & $\mathrm{GaO}$ & 0.022 & $\mathrm{WO}_{7}$ & $<0.01$ \\
\hline $\mathrm{Fe}_{2} \mathrm{O}_{3}$ & 15.9 & $\mathrm{GeO}_{2}$ & 0.011 & $\mathrm{ZnO}$ & 0.053 \\
\hline \multirow[t]{2}{*}{$\mathrm{TiO}_{2}$} & 1.52 & $\mathrm{HgO}$ & 0.011 & $\mathrm{ZrO}_{2}$ & 0.029 \\
\hline & Station B & Montana: & Subbituminous & Coat Ashb & \\
\hline $\mathrm{SiO}_{2}$ & 34.2 & $\mathrm{Fe}_{2} \mathrm{O}_{3}$ & 12 & $\mathrm{Na}_{2} \mathrm{O}$ & 0.3 \\
\hline $\mathrm{Al}_{2} \mathrm{O}_{3}$ & 15 & $\mathrm{CaO}$ & 18 & $\mathrm{~K}_{2} \mathrm{O}$ & 0.3 \\
\hline $\mathrm{TiO}_{2}$ & 0.8 & MgO. & 4.5 & $\mathrm{SO}_{3}$ & 17 \\
\hline
\end{tabular}

$a_{H}$. F. Yancey and M. R. Geer, Coal Preparation, pp. 1-38, American Institute of Mining, Metallurgical, and Petroleum Engineers, Inc., New York, 1968.

$\mathrm{b}_{\mathrm{W}}$. R. Buckley et al., Power. Magazine, p. 20 (July 1974). 
coal as an alternate fuel is expected to play a major role in industrial fuel planning in the long run but only a limited one in the immediate future.

\subsection{ELECTRICITY}

Electricity is obviously a clean form of energy. The direct use of electricity in industrial processing and heating has several advantages over direct fuel use: (1) higher efficiency of heat utilization, (2) environmentally clean, and (3) less cost in capital investments such as storage, transportation, piping, pumping, and combustion systems. In terms of energy, the cost of electricity is presently much higher than fuel oil, coal, or natural gas simply because electricity is generated from these fuels at a typical conversion efficiency of about $35 \%$. In 1974, the average price of electricity for industry was $\$ 6$ per million Btu. ${ }^{3}$ Despite its high price, electricity still is a nearly ideal substitute for natural gas in some processing furnace applications. In fact, several respondents indicated that the manufacturing industry is in general already converting to electric power where practical. For example, three years ago, one major furnace company manufactured only natural gas furnaces, but now $40 \%$ of this company's production is electric furnaces. As this was a general trend identified in this assessment, the question is raised regarding the electric power generation capacity to meet the needs resulting from this conversion. In view of the rapidly rising cost of electric energy and a potential shortage of investment capital for expansion of utility services, conversion from natural gas to electricity is not a generally desirable alternative at this time. The use of electricity to make up the shortage of natural gas appears to be relatively limited in the forseeable future.

\subsection{LOW BTU GASES}

Low Btu gases that are produced from the gasification of coal or oil or reclaimed from steelmaking processes are also considered as alternate fuels in this assessment. The gas composition depends on its production process (Table 3.6). Since there is a significant amount 
Table 3.6. Typical Compositions of Low Btu Gases and Natural Gas ${ }^{a}$

\begin{tabular}{|c|c|c|c|c|c|c|c|c|c|c|}
\hline Parameter & $\begin{array}{c}\text { Natural } \\
\text { Gas }\end{array}$ & Lurgi & $\begin{array}{l}\text { Fluidized-Bed } \\
\text { Coal. Gas }\end{array}$ & $\begin{array}{l}\text { BOM } \\
7644\end{array}$ & Winkler-1 & Winkler-2 & $\begin{array}{l}\text { Producer Gas } \\
\text { (from coal) }\end{array}$ & $\begin{array}{c}\text { Blast Furnace } \\
\text { Gas }\end{array}$ & $\begin{array}{l}\text { Blue Water } \\
\text { Gas }\end{array}$ & Coal Gas \\
\hline $\mathrm{O}_{2}$ & & & & & & & & & & 0.4 \\
\hline $\mathrm{N}_{2}$ & 0.5 & 30.2 & 50.4 & 54.7 & 55.3 & 1 & 52.4 & 60 & 4.5 & 6.2 \\
\hline $\mathrm{CO}_{2}$ & 1.8 & 10.7 & 0.5 & 7.2 & 10 & 19 & 4 & 11 & 4.7 & 4 \\
\hline co & & 10.7 & 31.8 & 2.0 & 22 & 38 & 29 & 27 & 41 & 18 \\
\hline $\mathrm{H}_{2}$ & & 15.7 & 15.6 & 15.5 & 12 & 40 & 12 & 2 & 49 & 49.4 \\
\hline $\mathrm{CH}_{4}$ & 93.3 & 4.4 & 0.5 & 2.8 & 0.7 & 2 & 2.6 & & 0.8 & 20 \\
\hline $\mathrm{C}_{2} \mathrm{H}_{6}$ & 3.49 & & & & & & & & & 2 \\
\hline $\mathrm{C}_{3} \mathrm{H}_{8}$ & 0.68 & & & & & & & & & \\
\hline $\mathrm{C}_{4} \mathrm{H}_{20}$ & 0.18 & & & & & & & & & \\
\hline $\mathrm{C}_{5} \mathrm{H}_{12}$ & 0.04 & & & & & & & & & \\
\hline $\mathrm{H}_{2} \mathrm{O}$ & & 27.8 & 0.5 & & & & & & & \\
\hline $\mathrm{H}_{2} \mathrm{~S}$ & & 0.5 & 0.7 & & & & & & & \\
\hline \multicolumn{11}{|c|}{ Stolch1ometric fuel/a1r: } \\
\hline Ratio (By vol) & 0.103 & 0.923 & 0.815 & 0.899 & 1.141 & 0.488 & 0.817 & 1.448 & 0.450 & 0.252 \\
\hline LHV, Btu/scf & 930 & 121 & 154 & 132 & 110 & 250 & 150 & 92.3 & 274 & 422 \\
\hline HHV, Btu, scf & 1030 & 150 & 163 & 143 & 17 & 272 & 158 & 93.3 & 299 & 471 \\
\hline \multicolumn{11}{|c|}{ Stoichlometric temperature: } \\
\hline Rise, ${ }^{\circ} \mathrm{F}$ & 3495 & 2312 & 3007 & 2638 & 2438 & 3501 & 2871 & 2205 & 3769 & 3601 \\
\hline $\mathrm{H}_{2} / \mathrm{CO}$ (by vol) & & $1.46 i$ & 0.491 & 7.75 & 0.545 & 1.053 & 0.414 & 0.074 & 1.195 & 2.744 \\
\hline
\end{tabular}

a Source: Used with permission from Power Magazine, p. 62 (June 1974). 
of $\mathrm{CO}$ and $\mathrm{N}_{2}$ in these low Btu gases, the stoichiometric fuel/air ratios for low Btu gases are higher than for natural gas. The heating values of these low Btu gases are around $300 \mathrm{Btu} / \mathrm{ft}^{3}$. The technology of coal gasification to produce low Btu gases is such that this fuel is not economically feasible at present and may not be for ten years or more. However, in the iron and steel industries, both the coke oven gas and the blast furnace gas, which have traditionally been used as fuels, can replace natural gas to a great extent. For the immediate term, the use of low Btu gases as an alternate fuel is only applicable where their production occurs as a part of some other primary process.

\subsection{REFERENCES}

1. Minerals Yearbook, Vol. 2, Bureau of Mines, Washington, D.C., 1972.

2. 1972 Census of Manufacturers, U.S. Census Bureau, Washington, D.C.

3. The 1975 Energy Management Guidebook, ed. by Power Magazine, McGrawHil1, New York, 1975.

4. 1974 Gas Facts, American Gas Association, Arlington, Virginia, 1975.

5. U.S. Energy Outlook - Gas Demand, National Petroleum Council, Washington, D.C., 1975.

6. Annual Statistical Review, American Petroleum Institute, Washington, D.C., 1975.

7. R. W. Marshall, "An Introduction to the Use of Today's Fuel Oil," BuzZ. Am. Cercom. Soc. 54(9): 774 (1975).

8. 1974 Keystone Coal Industry Manual, McGraw-Hi11, New York, 1974. 
THIS PAGE

\section{WAS INTENTIONALLY LEFT BLANK}


4. ASSESSMENT BY INDUSTRY OF FUEL CONVERSION IMPACT ON INDUSTRIAL REFRACTORIES AND REFRACTORY INSULATIONS IN THE IMMEDIATE TERM

As discussed previously, natural gas has become a primary fuel for most industries in the U.S. during the past two decades. As this fue1 became more available following World War II, industrial and residential users converted from other fuels, primarily coal, to natural gas because of :

1. its relatively low cost per Btu,

2. the desirable flame properties peculiar to natural gas,

3. the relatively clean combustion products from natural gas compared to coal, and

4. the relatively low capital investment required for conversion to use of natural gas.

Within the past five years or so, the demand for natural gas has exceeded the supply in various regions of the U.S. and the suppliers have begun to limit the gas available to industrial users during periods of high demand in order to ensure gas availability to residential and commercial customers.

The interruptable nature of most of the industrial contracts now available for natural gas has caused some companies to install alternative fuel supply systems that could be used during the period when the natural gas supply is interrupted by the supplier. The availability of natural gas for industrial use has been decreasing in many areas; therefore, some industrial firms are planning to make relatively permanent conversion to an alternate fuel where possible. The relatively low cost of natural gas compared to any other fuel, on a heat equivalent basis, still provides a strong incentive for industry to use it wherever and whenever possible. To determine the present status of industrial planning for conversion from natural gas to alternate. fuels, an assessment was conducted during February, March, and April 1976. About 100 selected companies were contacted by phone to determine their present plans, and several were subsequently visited in order to obtain more detailed information or to see specific equipment operated with an 
alternate fuel. Certain companies within the more energy-intensive industries were identified and contacted to determine:

1. the present mix of fuels that provide the firm's energy needs,

2. future plans for conversion from natural gas to alternate fuels, and

3. direct company experience with alternate fuels and the effect of these fuels upon refractories in combustion equipment.

Most firms cooperated with this assessment, although some were openly negative. In general, industrial interest in alternate fuels was quite high with most interest in oil. Many firms are confronted almost daily with interruptible natural gas supplies and have by necessity installed alternate fuel systems.

\subsection{THE CHEMICAL AND PETROCHEMICAL INDUSTRIES}

Some chemical and petrochemical companies plan to convert boilers and process heaters from natural gas to alternate fuels in the near future. One large chemical and petrochemical company indicated that in 1976 its energy use according to fuel type is expected to be $40 \%$ natural gas, $30 \%$ fuel oil, and $30 \%$ coal; they plan to decrease the use of natural gas to only $10 \%$ in 1979 . For 1974, another company had used $67 \%$ natural gas, $15 \%$ fuel oil, and $18 \%$ coal. In this case, they plan to reach the goal of $29 \%$ natural gas, $52 \%$ fuel oil, and $21 \%$ coal in 1980 . One large company experienced a natural gas shortage in 1975 alone of one trillion cubic feet or about $5 \%$ of the total they needed. While exploring the possibility of opening their own natural gas wells, this company plans to convert to fuel oil and coal as soon as practical. While initiating such large scale fuel conversion activities, many companies indicated they have assumed an available supply of alternate fuels such as No. 6 and No. 2 oils and coal in both the immediate and in the long term. One major petrochemical manufacturer admitted that the long-range planning on energy resources and fuel use was risky because of their assumptions on the availability of alternate fuels. Their policy was to change natural gas burners to dual fuel burners completely by 1978 and only to invest in new coal-fired 
steam boilers in the future, assuming environmental regulations could be met while burning coal.

A comparison of costs shows that boiler and process heaters converted to No. 6 oil are typically $20 \%$ more expensive than those operating with No. 2 oil, and coal firing unit costs are about triple that of No. 6 oil firing units. The present and future transportation costs for coal are a major concern of many companies contacted. One source indicated that, in one particular case, the conversion cost for coalfired boilers is more than the original cost of the steam plant that is being converted. Small industrial boilers are less adaptable to fuel. changes than larger boilers. These small units become uneconomical with the high cost of control, fuel storage, and piping equipment required. Since fuel costs are a more protracted expenditure, the company can often better afford higher priced natural gas and fuel oils than the expensive sulfur removal devices and the fuel handling equipment required to burn coal. Therefore, the small and medium size industrial boilers will probably continue to use natural gas and distillate or residual fuel oils.

Present plans in some of the chemical and petrochemical industries are to use No. 6 oil in cold-wall boilers because of the belief that this will be relatively safe as far as boiler life and integrity is concerned. Th1s safety is assumed because the firebox of cold-wall boilers contains a minimum of ceramic refractories or insulations in contact with the flame and combustion products. In some cases, a double-mode firing with coal and heavy oil in boilers helps to reduce fuel oil costs and to meet local emission standards.

One company mentioned their experience with No. 6 oil-fired boilers in the late 1960s. The No. 6 oil used was from Venezuelan crude oil, which contains relatively high sulfur and vanadium contents. Problems such as tube clogging and reduction in heat transfer characteristics due to the huge amount of solid deposits in the combustion chamber soon developed and led to shutdown and costly cleaning. Because of this incident, this company later imposed a tight control over the sodium and vanadium contents in the No. 6 oil they purchased; i.e., sodium less than $50 \mathrm{ppm}$ and vanadium less than $150 \mathrm{ppm}$. 
McMullen, ${ }^{1}$ Walls and Proctor ${ }^{2}$ and Palfreyman ${ }^{3}$ also reported marine and stationary boiler problems associated with the use of Bunker $C$ oil, which is essentially equivalent to the No. 6 grade. Fireclay bricks and castables are usually used in these boilers. These fireclay refractories are typically classified as low-duty, medium-duty, high-duty, or super-duty in the order of increasing service performance at high temperature. More than 20 years ago, Jones and Hardy ${ }^{4}$ pointed out that heavy oils containing vanadium are highly destructive to fireclay brick in boilers. The other impurities such as alkali and alkaline earths are less detrimental as compared to vanadium. These experimental observations were based on results of a slagging test. Unfortunately, the seriously detrimental effect of heavy oil ash on fireclay refractories in boilers and process heaters has apparently been known by relatively few people, and was unknown to many technical personnel in the chemical and petrochemical industries. The improper choice of refractory for use with residual oils has cost the chemical and petrochemical industries many millions of dollars in maintenance costs and repairs. ${ }^{5}$

Due to present concerns about potential detrimental effects of impurities in No. 6 oil, present industrial plans are generally to use No. 2 oil in process heaters since these units contain a significant amount of refractories. The chamber wall temperature in this applicatlun is relatively high, about $982-1093^{\circ} \mathrm{C}\left(1800-2000^{\circ} \mathrm{F}\right)$ as compared to $593^{\circ} \mathrm{C}$ $\left(1100^{\circ} \mathrm{F}\right)$ for boilers. Some respondents commented that sulfuric acid as a combustion product penetrated through fiber refractory insulations in their equipment and corroded the metal lining in their reactors and process heaters. Because of the high permeability of sulfur oxides through such insulations as fiber blankets; a protective coating on the inner surface of metal liners is required if high sulfur oil is to be used.

There are some heating processes that require either a high degree of cleanliness or precision control of temperatures. These requirements cannot readily be met if alternate fuels are used. An example of this was a food-related product cited by one company in the manufacturing of a particular phosphate compound. 
The need for precise control of temperature to prevent hazardous explosions in the ammonia reformer in the fertilizer industry dictates that natural gas be used. Other than specialized requirements such as these, the conversion to distillate and heavy oils in the chemical and petrochemical industries can be extensive.

\subsection{THE IRON AND STEEL INDUSTRY}

According to the American Iron and Steel Institute, ${ }^{6}$ natural gas accounted for $17 \%$ of the total amount of energy consumed in the iron and steel industries in 1974 and this amounted to $7 \%$ of the industrial natural gas demand in the whole country. There are three principal methods of steel melting: open hearth, basic oxygen, and the electric arc. Open-hearth furnaces, because of their relatively low productivity and high capital investment, are gradually being phased out and replaced by basic oxygen and electric furnaces. Open-hearth furnaces consume much more natural gas than the other two types of furnaces. Because of this trend away from open-hearth furnaces, the need for natural gas for steel melting will steadily decline. The most energy-intensive process in the steel industry is the operation of blast furnaces. This process consumes about 18 million Btu of energy per ton of iron, of which 0.5 million Btu typically comes from natural gas, which has been used as a supplemental fuel in the blast furnace to reduce the quantity of coke required and to increase the production rate. ${ }^{7}$ In this application, fuel oil probably will replace natural gas. The blast furnace usually is lined with super-duty or high-duty fireclay refractories, which could be subjected to attack by fuel oil ash following. such a fuel conversion.

Certain steel companies have indicated that they are planning to expand coke oven capacity where applicable and thus provide sufficient coke oven gas to make up for a lack of natural gas. Those companies that do not have coke ovens are facing a necessity for fuel conversion. In converting to alternate fuels, steel companies are concerned about possible contamination of their products by trace elements in the fuel. For those heat-treatment furnaces where a clean annealing 
environment and high degree of uniformity in temperature are required, natural gas was mentioned as the only suitable fuel at present. Soaking pits, heating, and reheating furnaces for metal rolling and forming, which in the past used a high percentage of natural gas and blast furnace gas, are being scheduled for conversion to No. 2 and No. 6 oils. The types of refractory used in these applications cover a broad range; fireclay $\left(26-45 \% \mathrm{Al}_{2} \mathrm{O}_{3}\right)$, sillimanite $\left(45-65 \% \mathrm{Al}_{2} \mathrm{O}_{3}\right)$, mullite $(65-75 \%$ $\left.\mathrm{Al}_{2} \mathrm{O}_{3}\right)$, bauxite based $\left(75-90 \% \mathrm{Al}_{2} \mathrm{O}_{3}\right)$, chrome-magnesite, chrome, and magnesite in brick form or monolithic form have all been used. All these refractories are subjected more or less to attack by vanadium and sodium in fuel oils at temperatures ranging from 1149 to $1427^{\circ} \mathrm{C}$ $\left(2100\right.$ to $2600^{\circ} \mathrm{F}$ ), which is the typical temperature in the walls of the soaking pits and reheating furnaces. In general, higher $\mathrm{Al}_{2} \mathrm{O}_{3}$ or $\mathrm{MgO}$ content together with low impurities (such as calcium, boron, and alkalies) tend to increase the corrosion resistance of a refractory. One company reported that in their soaking pits, which were fired by No. 6 oil, the wall opposite the burner and the roof were essentially washed out or fluxed away due to the interactions between the refractory material and the combustion products in the fuel oil. Another company commented that in their experience the refractories used in steel soaking pits and reheating furnaces nust be upgraded by incraasing the $\mathrm{Al}_{2} \mathrm{O}_{3}$ or $\mathrm{MgO}$ content prior to conversion to No. 6 oil.

At present, some steel companies feel that investments in waste heat recovery systems are good investments. However, conversion to a fuel such as No. 6 oil will result in a large quantity of combustion ash deposit in recuperators or waste heat boilers associated with soaking pits, heating or reheating furnaces, and cupolas. This indeed was recently discovered by one steel company. The reduced heat recovery efficiency and the increased maintenance labor were unanticipated costs.

As the steel continuous-casting process (in which soaking pits and reheating furnaces could be eliminated) becomes more popular in steelmaking, the total fuel consumption per ton of steel may be reduced by about $8 \%$ and such furnace problems would be reduced accordingly. ${ }^{8}$ It was estimated by one contact that by 1985 about $50 \%$ of the total U.S. steel production will come from the continuous-casting process. ${ }^{8}$ 
In the forging and fabrication part of the steel industry, the shortage of natural gas has been severe. One major steel forging company experienced nearly $50 \%$ curtailment of its natural gas requirement over the previous year. While considering drilling natural gas wells for their own use, these companies rebuilt furnaces and converted to dual burners to use No. 2 oil as standby. The furnace walls, which were formerly ceramic bricks as thick as $18 \mathrm{in.}$, were rebuilt to consist of 2 in. of fiber refractory materials backed up by 4 in. of mineral wool insulation. The temperature in the refractory in this application is about $871^{\circ} \mathrm{C}\left(1600^{\circ} \mathrm{F}\right)$. As a result of these modifications in their forging furnaces, the warm-up time was reduced significantly and the total savings in fuel was almost $75 \%$. Long-term operational performance of this furnace design has not been determined to date. In the forging and fabrication part of the steel industry, No. 2 oil is widely adopted because its use will be more compatible with the refractories used.

\subsection{THE ALUMINUM INDUSTRY}

Aluminum companies are interested in conversion from natural gas in the melting and remelting furnaces, as well as in the heating and reheating furnaces. One major aluminum company estimated that its use of natural gas will be negligible by 1979 compared with today's use, which represents more than $60 \%$ of the total energy spent on furnace heating and melting applications. Natural gas is widely used in all steps of aluminum production, including bauxite drying, alumina separation and calcination, melting, anode electrode manufacturing, rolling, extrusion, milling, and fabrication.

The general trend in the aluminum industry is to convert the reverberatory melting and remelting furnaces, heating and heat-treating furnaces, and anode bake ovens to No. 2 oil because of the curtailment of natural gas supplies. Propane currently is used by some of these companies as a standby fuel. One company contact expressed concern over the detrimental effect of combustion products of residual oils on the fireclay refractories used in anode bake ovens in which the temperature ranges from 1038 to $1316^{\circ} \mathrm{C}\left(1900\right.$ to $\left.2400^{\circ} \mathrm{F}\right)$. The main potential 
problem in these applications is refractory deterioration due to fuel ash attack. In an aluminum reverberatory furnace, the molten aluminum temperature is about $704^{\circ} \mathrm{C}\left(1300^{\circ} \mathrm{F}\right)$, but the temperature in the refractory above the metal line is usually 1093 to $1316^{\circ} \mathrm{C}\left(2000\right.$ to $\left.2400^{\circ} \mathrm{F}\right)$. The furnace below the metal line is typically lined with $75-90 \% \mathrm{Al}_{2} \mathrm{O}_{3}$ brick or $85 \% \mathrm{Al}_{2} \mathrm{O}_{3}$ phosphate-bonded brick. Above the metal 1ine, super-duty fireclay, plastic or castable refractory is typically used. The flue is lined with high-duty firebrick and the charging door is filled with super-duty castables. Silicon carbide brick bonded with silicon dioxide or silicon nitride and zircon brick are also used in the melting furnace. One company found that the roof and the wall above the metal line in the aluminum reverberatory melting furnace were seriously fluxed by the combustion products of No. 6 oil. Refractory linings had to be replaced by a higher $\mathrm{Al}_{2} \mathrm{O}_{3}$ content type of refractory. Although formerly not feasible, it now becomes economically attractive to invest in recuperators to preheat the combustion air. The main problem related to alternate fuel conversion is the recuperator material corrosion by the combustion products and traces of halide contained in the flue gas. ${ }^{9}$

Coal firing in aluminum reverberatory furnaces is being actively explored by one company we contacted. However, the test results are considered proprietary and were not available for this assessment. It is expected that the main difficulties with coal use will be coal ash slagging and corrosion in refractories, ash removal, and contamination in the aluminum melts.

\subsection{THE COPPER INDUSTRY}

Some copper companies using a significant quanitity of natural gas in their smelting and melting furnaces and converters are actively converting to alternate fuels. Currently, some copper companies have distillate oil on standby to supplement natural gas used in converters and reverberatory melting furnaces. One contact Indicated that the energy sources for current production of each ton of copper (which requires about 100 million $\mathrm{Btu}$ ) is: electricity, 54\%; natural gas, $27 \%$; fuel $0 i 1,14 \%$; and coal, $5 \%$. More than $50 \%$ of the total energy consumed 
in the smelting and melting processes, which use about $48 \%$ of the total production energy, comes from natural gas. The curtailment of natural gas forced the copper companies to convert mainly to fuel oils (distillate and residual). One company pointed out that their reverberatory melting furnaces that were converted to No. 6 oil were later changed to No. 2 oil because of observed deterioration in furnace refractories. Another company said that the high cost of using residual oil and the similarity of costs of residual and distillate oil made residual oil uneconomical.

The side walls of the copper reverberatory furnace usually are lined with chrome-magnesite or magnesite chrome, burned or chemically bonded brick, depending on the copper ore and melt. The roof is usually silica refractory, and basic bricks or high $\mathrm{Al}_{2} \mathrm{O}_{3}$ bricks are also used. The temperature on the inner furnace wall is about $1649^{\circ} \mathrm{C}\left(3000^{\circ} \mathrm{F}\right)$. Oxygen enrichment of the combustion air was considered by many of these companies. ${ }^{10}$ Such enrichment will increase the flame temperature as well as the melt temperature and will require linings of higher purity magnesia compositions. Coal firing in the copper reverberatory furnaces is in the exploratory stage. In addition to the inherent refractory degradation associated with coal firing, a main concern is the capital cost of converting to coal. Thus, in the near term, distillate and residual oils will continue to be the main alternate fuels in the copper industry.

\subsection{THE GLASS INDUSTRY}

The glass industry is gas-intensive. From batch handling and melting to forming and postforming, natural gas is extensively used. One major glass manufacturer reported that their energy use data in recent years clearly indicates a trend in the reduction of natural gas use, which has been largely compensated for by the increased use of fuel 011 and electricity. In fact, some glass company representatives spoke of entering into an "electricity age."1l The mixing of fossil fuel and electric power has been a common practice in glass pots and tanks in the past. The electric boosters using molybdenum electrodes to generate strong convection currents in the molten glass can increase the melting efficiency from 10 to $40 \%$. This higher efficiency offsets the high 
electric rates ( $\$ 6 / \mathrm{million} B t u)$ relative to natural gas and fuel oils. However, the refractory life of an electric melter is only about half the life of an equivalent conventional glass tank. A technical breakthrough in the near future regarding refractory technology and materials is required to make the electric melter more attractive to glass manufacturers. The glass industry, facing the severe curtailment of natural gas, is intensely interested in better refractory use and combustion control for gas or oil fired tank or pot furnaces.

Glass melting furnaces are operated at high temperatures ranging from 1538 to $1649^{\circ} \mathrm{C}\left(2800\right.$ to $\left.3000^{\circ} \mathrm{F}\right)$. The batch normally consists of silica and glass-forming components such as lime, soda, and borates. Most of the glass furnaces are equipped with regenerators in which the checkerwork bricks are first heated by the furnace exhaust gas. Large valves then redirect the gas flow, and combustion air is then passed through the checkerwork to be preheated. While one set of regenerators is supplying preheated air, the other set is being heated by the furnace exhaust gas. The crown of a glass tank furnace is built of silica brick covered on the cold side with refractory insulation. The bottoms are built of insulating firebricks covered by layers of high-duty firebricks on which high $\mathrm{Al}_{2} \mathrm{O}_{3}$ brick will form the support for the fused-cast $\mathrm{Al}_{2} \mathrm{O}_{3}$ or sintered zircon blocks that are supporting the melt. Sidewalls are usually made of high $\mathrm{Al}_{2} \mathrm{O}_{3}$ (higher than 45\%) or fused cast alumina refractories. The crown and upper sidewalls of the regenerator usually are built of basic or mullite refractory, while the lower sidewalls are super-duty firebricks. The upper checkerwork is usually basic bricks while the lower checkerwork is either basic or super-duty fireclay, depending on the service condition.

One company indicated that they were allotted only $85 \%$ of the natural gas they used in 1975, so they had to change to No. 6 oil. In this case, refractories were selected with greatest caution to ensure proper corrosion resistance. So far, little operational experience has been obtained from this particular facility. Because of refractory degradation, one company had to shut down their glass tanks, which were fired with high vanadium No. 6 oil. 
In addition to fuel oil, producer gas is also an alternate fuel. One respondent indicated that producer gas combustion needed preheating as well as combustion air preheating, and this required better design and selection of the checkerwork bricks in the regenerator.

Contacts in the glass industry generally indicate strong interest in alternate fuels and especially No. 2 oil for immediate term conversion due to their concern about potential detrimental reactions with No. 6 oil in their regenerators. The cost of constructing residual oil combustion systems has also been cited as a barrier to the wider use of No. 6 oil. Where the color requirement of the product glass is unaffected by the contaminants from coal ash, powdered coal has been experimentally used in a 100 ton/day glass tank for container manufacturing. ${ }^{12}$ But experience with the combustion of powdered coal in the glass industry is still very limited. It appears that coal burning in glass tanks is primarily of long-term interest. Number 6 oil and coal mixture slurry combustion is presently being actively investigated by a joint effort-involving more than 20 companies from several sectors of industry. The main technical problems are the prevention of separation of coal particles and oil, which leads to incomplete combustion and the refractory degradation by the combustion products. This type of alternate fuel seems unlikely to become practical for glass manufacture in the immediate future. In general, distillate oil and residual oils are considered by the glass industry as near-term alternate fuels.

\subsection{THE CERAMICS INDUSTRY}

The ceramics industry as a natural gas-intensive industry has been actively converting to alternate fuels due to recent severe gas curtailments. One major refractory producer plans to install dual burners to reduce within four years their consumption of natural gas from a present $60 \%$ of their total heating energy supply to less than $40 \%$. Due to the relatively high firing temperatures required for their products, refractory companies are concerned about potential detrimental reactions that can occur with use of residual oils. The ceramics industry is thus changing their kilns to dual burners with No. 2 oil as standby. Tunnel 
kilns are the primary method for firing all types of refractories. The temperature in the hot zone or burning zone of a tunnel kiln ranges from 1093. to $1760^{\circ} \mathrm{C}\left(2000\right.$ to $\left.3200^{\circ} \mathrm{F}\right)$. The hot zone is usually built of superduty, high-alumina firebricks or basic bricks. Medium-duty firebricks are used in the heating and cooling zones and air-lock zones. The arched roof in this region is usually silica brick or may be a basic brick in high-temperature kilns.

One structural clay product company successfully converted to powdered coal a large tunnel kiln firing face brick. The kiln has been operated with this fuel for two years. The temperature in the hot zone is kept at temperatures below $1093^{\circ} \mathrm{C}\left(2000^{\circ} \mathrm{F}\right)$, since the ash of the particular coal used fuses at temperatures of 1149 to $1260^{\circ} \mathrm{C}$ $\left(2100\right.$ to $\left.2300^{\circ} \mathrm{F}\right)$ and will corrode the refractories at these high temperatures.

Coal combustion is only applicable where the contamination from coal ash on the fired products can be tolerated. Coal-firing kilns currently cost about three times their oil system equivalents. Despite the high cost of the capital investment, the moderate price and abundant supply of suitable coal as compared to high-priced oil and scarce natural gas has been a strong incentive for the ceramics industry to begin to convert to coal for application temperatures lower than $1093^{\circ} \mathrm{C}\left(2000^{\circ} \mathrm{F}\right)$. One ladle brick company stated that they planned to convert to coal from today's zero percent to 35\% of the total combustion units by 1979 .

In the area of No. 6 oil burning, two companies pointed out that they burned No. 6 oil in their calcining kilns many years ago, but problems of refractory interactions with fuel ash ruled out the continuing use of this type of fuel. Today the calcining kilns generally are fired with No. 2 oil or natural gas. In the immediate term, respondents indicated that distillate oil is the main alternate fuel to replace natural gas. The effects of No. 6 oil conversion on refractories in high-temperature ceramic kilns could obviously be serious, and is a major concern in this industry. 


\subsection{THE CEMENT INDUSTRY}

The cement industry is steadily converting to coal. Six years ago, about $99 \%$ of all cement kilns in this country were fired with natural gas. At present, only slightly over $50 \%$ of the cement kilns are fired by natural gas. Pulverized coal combustion is apparently satisfactory for this application. One company contact predicted that by the end of 1979 essentially all their cement kilns will be coal fired.

There are two types of kilns for cement production, the verticalshaft kiln and the rotary kiln. For lime kilns, the operation temperature in a vertical-shaft kiln is at least $1093^{\circ} \mathrm{C}\left(2000^{\circ} \mathrm{F}\right)$, while it is $1427^{\circ} \mathrm{C}\left(2600^{\circ} \mathrm{F}\right)$ in a rotary kiln. The burning zone is built of superduty, basic, or high-alumina dense bricks. Medium-duty fireclay bricks or castables are used in the colder portions of the kiln. The highest temperature in the hottest zone of a cement kiln is about $1649^{\circ} \mathrm{C}\left(3000^{\circ} \mathrm{F}\right)$. The main function of the hot zone lining is to support a coating on the refractory 2 or 3 in. thick, which is constantly renewed during cement production: The composition of the coatings is similar to that of the clinker and serves as a protection for the refractories.

At present, the supply of coal is adequate and coal combustion is suitable for this industry. The high price of fuel oils relative to coal makes fuel oils less favored. The cement industry's primary fuel will continue to be coal.

\subsection{OTHER INDUSTRIES}

In addition to the above major industries, other industries also face problems in converting to alternate fuels. This section outlines fuel conversion prospects and their effects on refractories in other industries and in electric power utilities. Petroleum refining companies burn natural gas and oil in their boilers and process reactors. One company indicated that the distribution by fuel types in 1975 was $90 \%$ oil and $10 \%$ natural gas. During that year, this company's conversion to fuel oil cut by half their consumption of natural gas to an overall total of only $5 \%$. The major increase in the use of residual oil was with boilers in which the small amount of refractory lining and the 
relatively low operation temperature $\left[593^{\circ} \mathrm{C}\left(1100^{\circ} \mathrm{F}\right)\right]$ would cause only an ash problem with minimal metal corrosion. On the other hand, the linings of reactors such as those used for the hydrodesulfurization reactions, which are normally operated at elevated temperatures and under high pressures, would be subject to attack by the fuel ash of residual oils. These reactors were thus converted to distillate oils. The refractory linings in chemical reactor vessels are usually superduty fireclay, insulating castable, or gunning mixes in monolithic forms. Although producer gas is also an alternate fuel, the general trend in the petroleum refining industry is to use residual and distillate oils.

In the food industry and paper industry, boilers to generate steam and other miscellaneous relatively low-temperature furnaces are the major heating applications. Companies within these industries facing natural gas curtailment are converting their boilers to fuel oil and coal. One paper company burned waste wood in their boilers to make up the shortage of natural gas. The food industry must use natural gas in some of their heaters and driers due to the stringent cleanliness and quality requirements for their products.

In 1973, electric power utilities accounted for more than $50 \%$ of the national total demand for residual oils and for about $7 \%$ of the total amount of distillate oils in the U.S. ${ }^{13}$ These energy needs were almost equal to the total national industrial demand for both residual and dist1llate oils. The fuel conversion plans of electric power utilities will therefore greatly influence the availability of different types of fuels to industrial users. The federal government is requiring certain electric power plants to convert to coal from oil. ${ }^{14}$ A total of 155 boilers at 79 power stations that were originally designed for coal combustion have capacities larger than $25 \mathrm{MW}$. These boilers were later converted to fuel oil or gas. Their conversion back to coal now would reduce domestic fuel oil demand by 0.5 million bbl/day, and natural gas by about 550 million $\mathrm{ft}^{3} /$ day. Correspondingly, the coal demand would increase by 48 million tons/year. 
Despite the high investment cost, some industrial steam plants will be converted to coal. In smaller units; electrode boilers are becoming widely used. Because of the very different combustion properties of coals from different sources, consideration must be given to the fuel/air ratio, heat transfer characteristics, and flame geometry suitable for the particular type of coal burned. A respondent indicated that, in one case, improper burner adjustment resulted in severe damage to the burner tile that was bullt of $99 \%$ fused cast alumina. The combustion of coal containing $25 \%$ ash reduced the service life of this dense refractory from six years to only six weeks because of severe erosion and slagging. The effects on the furnace refractories of conversion to coal by steam generation plants will require better control of the combustion and better selection of refractories.

\subsection{REFERENCES}

1. J. J. McMullen, "Boiler Problems Associated wi.th Use of Bunker-C Fuel," Combustion 42 (April 1960).

2: W. A. Walls and W. S. Proctor, "Water Wash of Bunker-C Retards Boiler Slag on Atlantic Tanker," Combustion 43 (April 1960).

3. M. Palfreyman, "Investigation of Refractory Failure in a Boiler Combustion Chamber," J. Can. Ceram. Soc. 41: 103 (1972).

4. M.C.K. Jones and R. L. Hardy, "Petroleum Ash Components and Their Effect on Refractories," Ind. Eng. Chem. 11: 2615 (1952).

5. J. R. Wilson, "Understanding and Preventing Fuel Ash Corrosion," paper no. 12, presented at NACE 1976 Annual Meeting, March 22-23, Houston, Texas.

6. Energy Consumption in the Steel Industry, American Iron and Steel Institute, Washingtọ, D.C., 1975.

7. U.S. Energy Mdt?.nok - Gas Demand, National Petroleum Council, Washington, D.C., 1973.

8. R. N. Leidner, "Some Problems Facing the Steel Industry in Energy Availability and Conservation," presented at National Conference on Effective Utilization of Energy in Industry, March 23-24, 1976, Battelle Memorial Institute, Columbus, Ohio. 
9. M. C. Mangalick, "Improvement in Thermal Efficiency of Aluminum. Reverberatory Furnaces," p. 101 in Energy Use and.Conservation in the Metals Industry, ed. by Y. A. Chang, W. M. Danver, and J. M. Cigan, 1975:

10. K. Parameswaran and R. Nadkarni, "Energy Considerations in Copper, Lead, and Zinc Smelting," p. 27.1 in Energy. Use and Conservation in the Metals Industry, ed. by Y. A. Chang, W. M. Danver, and J. M. Cigan, 1975.

11. C. W. Hibscher and W. R. Steitz, "Challenge to U.S. Glass Manufacturers in These Energy-Critical Times," Buzl. Am. Cercom. Soc. $54(6)$ : 571 (1975).

12. K. A. Miller and C. V. Fogelberg, "Pulverized Coal-Air Burners for Glass Tanks," p. 12 in The GLass Industry, March 1975.

13. Annual Statistical Review, p. 21-22, American Petroleum Institute, Washington, D.C., 1975.

14. "FEA Ordering Many Boilers to Burn Coal Instead of 0i1," Power 33 (July 1975). 


\section{INTERACTIONS OF ALTERNATE FUEL COMBUSTION PRODUCTS WITH REFRACTORIES AND REFRACTORY INSULATIONS}

\subsection{COMBUSTION PRODUCTS FORMATION}

Since fuel oil was identified previously as the alternate fuel for most industries in the immediate term, the impact of industrial fuel conversion will thus be assessed primarily from the analysis of the interactions between the fuel oil combustion products and the refractory materials in the furnace.

The most abundant impurities in fuel oils and particularly residuals, are usually vanadium, sodium, and sulfur. At combustion temperatures, these elements form oxides such as $\mathrm{V}_{2} \mathrm{O}_{5}, \mathrm{Na}_{2} \mathrm{O}$, and $\mathrm{SO}_{3}$. Under appropriate atmospheric conditions, other vanadium oxides could be formed as well. Notably, the refractory oxides $\mathrm{V}_{2} \mathrm{O}_{3}$ and $\mathrm{V}_{2} \mathrm{O}_{4}$, which have melting points of $1970^{\circ} \mathrm{C}\left(3578^{\circ} \mathrm{F}\right)$ and $1637^{\circ} \mathrm{C}\left(2979^{\circ} \mathrm{F}\right)$ can be produced at sufficiently low oxygen potentials. When compared with $\mathrm{V}_{2} \mathrm{O}_{5}$, which melts at $690^{\circ} \mathrm{C}\left(1274^{\circ} \mathrm{F}\right), \mathrm{V}_{2} \mathrm{O}_{3}$ and $\mathrm{V}_{2} \mathrm{O}_{4}$ are in fact quite refractory. As a result, it has been suggested that the atmosphere in a combustion chamber containing vanadium should be kept at reducing conditions by using a minimum amount of excess air to suppress the formation of $\mathrm{V}_{2} \mathrm{O}_{5}$, but favoring production of $\mathrm{V}_{2} \mathrm{O}_{3}$ and $\mathrm{V}_{2} \mathrm{O}_{4} \cdot{ }^{1}$ It is generally believed that this condition will reduce the extent of vanadium oxide corrosion in refractories. Systematic operational verification of this hypothesis is very. scarce.

The system $\mathrm{Na}_{2} \mathrm{O}-\mathrm{V}_{2} \mathrm{O}_{5}$ has been the subject of many investigations, but results are inconsistent and sometimes contradictory. Wilson ${ }^{2}$ recently reinvestigated the system $\mathrm{V}_{2} \mathrm{O}_{5}-\mathrm{Na}_{2} \mathrm{O}$ (Fig. 5.1). An important feature of this system is that the liquidus temperature and the melting points of sodium vanadate compounds depended on the oxygen partial pressure. The melting points of $\mathrm{Na}_{2} \mathrm{O} \cdot 3 \mathrm{~V}_{2} \mathrm{O}_{5}$ and $\mathrm{Na}_{2} \mathrm{O} \cdot 6 \mathrm{~V}_{2} \mathrm{O}_{5}$ decrease with increasing oxygen partial pressure. The melting point could be suppressed as much as $100^{\circ} \mathrm{C}\left(180^{\circ} \mathrm{F}\right)$ if the oxygen partial pressure is increased from 0.2 atmosphere to 1 atmosphere. Thus the corrosion in pressurized conditions such as gas turbines and petrochemical reactors 


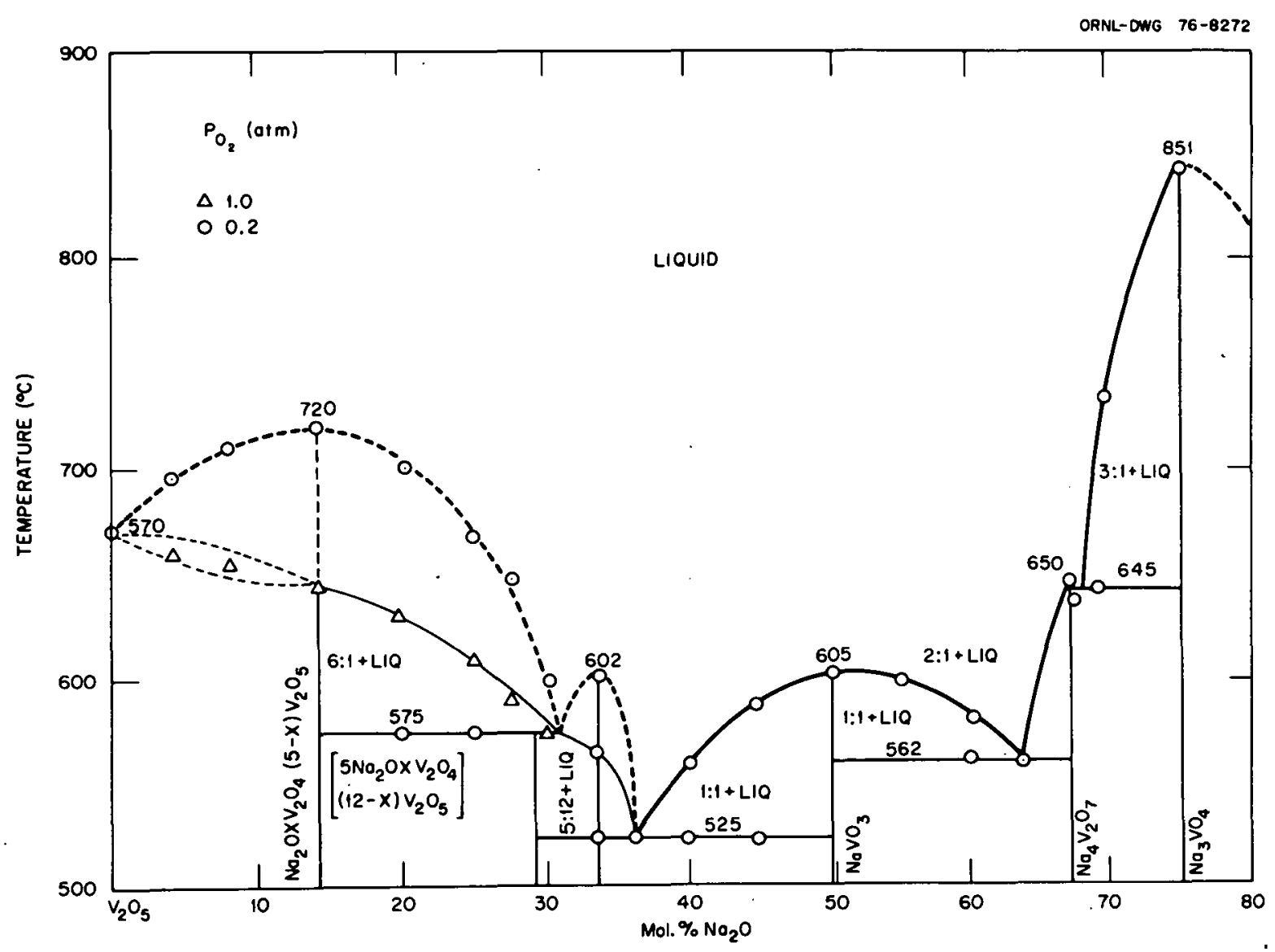

Fig. 5.1. The Binary $\mathrm{V}_{2} \mathrm{O}_{5}-\mathrm{Na}_{2} \mathrm{O}$ Phase Diagram at Two Oxygen Partial Pressures. Reprinted with permission from R. C. Kerby and J. R. Wi.lson, Con. J. Chem. 51: 1033 (1973).

will be significantly higher from ambient atmosphere applications. This phenomenon also explains the scatter in the melting points and liquidus temperatures in earlier investigations in which the oxygen activity was not controlled. There are three eutectics, one peritectic, and five compounds identified (Table 5.1). The lowest eutectic temperature is $525^{\circ} \mathrm{C}\left(977^{\circ} \mathrm{F}\right)$.

Sulfur trioxide and dioxide formed by combustion of sulfur bearing fuel oil will be at equilibrium and their chemical potentials will be determined by the oxygen partial pressure associated with the reaction:

$$
\mathrm{SO}_{2}(g)+1 / 2 \mathrm{O}_{2}(g) \rightarrow \mathrm{SO}_{3}(g)
$$


Tab.le 5.1 Invariant Points in the $\mathrm{V}_{2} \mathrm{O}_{5}-\mathrm{Na}_{2} \mathrm{O}$ Binary System

\begin{tabular}{|c|c|c|c|c|}
\hline \multicolumn{2}{|c|}{$\begin{array}{l}\text { Composition } \\
\quad(\operatorname{mole} \%)\end{array}$} & \multirow[t]{2}{*}{$\begin{array}{l}\text { Temperature } \\
\left({ }^{\circ} \mathrm{C}\right)\end{array}$} & \multirow[t]{2}{*}{ Type of Invariant } & \multirow[t]{2}{*}{ Equilibrium Solid Phases } \\
\hline $\mathrm{V}_{2} \mathrm{O}_{5}$ & $\mathrm{Na}_{2} \mathrm{O}$ & & & \\
\hline 69 & 31 & 575 & Peritectic & $\begin{array}{l}\mathrm{Na}_{2} \mathrm{O} \cdot \mathrm{xV}_{2} \mathrm{O}_{4} \cdot(6-\mathrm{x}) \mathrm{V}_{2} \mathrm{O}_{5}+ \\
\quad 5 \mathrm{Na}_{2} \mathrm{O} \cdot \mathrm{xV}_{2} \mathrm{O}_{4}(12-\mathrm{x}) \mathrm{V}_{2} \mathrm{O}_{5}\end{array}$ \\
\hline 54 & 36 & 525 & Eutectic & $\begin{array}{l}5 \mathrm{Na}_{2} \mathrm{O} \cdot \mathrm{xV}_{2} \mathrm{O}_{4} \cdot(12-\mathrm{x}) \mathrm{V}_{2} \mathrm{O}_{5}+ \\
\quad \mathrm{NaVO}_{3}\end{array}$ \\
\hline 37 & 63 & 562 & Eutectic & $\mathrm{NaVO}_{3}+\mathrm{Na}_{4} \mathrm{~V}_{2} \mathrm{O}_{7}$ \\
\hline 32 & 68 & 645 & Eutectic & $\mathrm{Na}_{4} \mathrm{~V}_{2} \mathrm{O}_{7}+\mathrm{Na}_{3} \mathrm{VO}_{4}$ \\
\hline
\end{tabular}

The production of $\mathrm{SO}_{3}$ from fuels has been related to the amount of excess air used in the burner. Reid $^{3}$ found that the formation of $\mathrm{SO}_{3}$ can be prevented by burning residual oil with a minimum amount of excess air, preferably with less than $0.5 \%$ of oxygen remaining in the flue gas. At temperatures higher than $1200^{\circ} \mathrm{C}\left(2192^{\circ} \mathrm{F}\right)$, most sulfates decompose and sulfur is thus present only as $\mathrm{SO}_{3}$ or $\mathrm{SO}_{2}$. At lower temperatures, sulfates will be formed. Foster ${ }^{4}$ et al, examined the system $\mathrm{Na}_{2} \mathrm{SO}_{4}-$ $\mathrm{V}_{2} \mathrm{O}_{5}$. They found that $\mathrm{NaVO}_{3}, \mathrm{Na}_{2} \mathrm{O} \cdot 3 \mathrm{~V}_{2} \mathrm{O}_{5}, \mathrm{Na}_{2} \mathrm{O} \cdot 6 \mathrm{~V}_{2} \mathrm{O}_{5}$ are the only compounds formed with the evolution of $\mathrm{SO}_{3}$ at temperatures above $871^{\circ} \mathrm{C}$ $\left(1600^{\circ} \mathrm{F}\right)$. Baldwin ${ }^{5}$ et al., reported similar compounds with the exception of $\mathrm{Na}_{2} \mathrm{O} \cdot 3 \mathrm{~V}_{2} \mathrm{O}_{5}$. Instead, they observed formation of $5 \mathrm{Na}_{2} \mathrm{O} \cdot 12 \mathrm{~V}_{2} \mathrm{O}_{5}$. $\mathrm{Niles}{ }^{6}$ later confirmed that only three sodium vanadates can exist. Depending on the $\mathrm{Na} / \mathrm{V}$ ratio, the following reactions occur:

$$
\begin{gathered}
\mathrm{Na}_{2} \mathrm{SO}_{4}+\mathrm{V}_{2} \mathrm{O}_{5} \rightarrow 2 \mathrm{NaVO}_{3}+\mathrm{SO}_{3}, \\
\mathrm{Na}_{2} \mathrm{SO}_{4}+3 \mathrm{~V}_{2} \mathrm{O}_{5} \rightarrow \mathrm{Na}_{2} \mathrm{O} \cdot 3 \mathrm{~V}_{2} \mathrm{O}_{5}+\mathrm{SO}_{3}, \\
\mathrm{Na}_{2} \mathrm{SO}_{4}+6 \mathrm{~V}_{2} \mathrm{O}_{5}+\mathrm{Na}_{2} \mathrm{O} \cdot 6 \mathrm{~V}_{2} \mathrm{O}_{5}+\mathrm{SO}_{3},
\end{gathered}
$$




$$
\begin{aligned}
& 2 \mathrm{Na}_{2} \mathrm{SO}_{4}+4 \mathrm{~V}_{2} \mathrm{O}_{5} \rightarrow \mathrm{Na}_{2} \mathrm{O} \cdot 3 \mathrm{~V}_{2} \mathrm{O}_{5}+2 \mathrm{NaVO}_{3}+2 \mathrm{SO}_{3} \text {. } \\
& 2 \mathrm{Na}_{2} \mathrm{SO}_{4}+9 \mathrm{~V}_{2} \mathrm{O}_{5} \rightarrow \mathrm{Na}_{2} \mathrm{O} \cdot 3 \mathrm{~V}_{2} \mathrm{O}_{5}+\mathrm{Na}_{2} \mathrm{O} \cdot 6 \mathrm{~V}_{2} \mathrm{O}_{5}+2 \mathrm{SO}_{3},
\end{aligned}
$$

At temperatures 1 ower than $1093^{\circ} \mathrm{C}\left(2000^{\circ} \mathrm{F}\right), \mathrm{SO}_{3}$ may lead to the formation of sulfates. The stability of the condensed sulfate phase is determined by the temperature and the equilibrium $\mathrm{SO}_{3}$ pressure on the deposit. Other metallic contaminants in fuels such as potassium, iron, calcium, aluminum, lead, and silicon will also form oxides at combustion temperatures. These oxides will react then with vanadium pentoxide, make less of it available for reaction with sodium, and thus result in a higher effective $\mathrm{Na} / \mathrm{V}$ ratio. This will produce sodium vanadates of higher $\mathrm{Na} / \mathrm{V}$ ratios.

The vapor pressure of $\mathrm{V}_{2} \mathrm{O}_{5}$ has been measured and is expressed by ${ }^{7}$

$$
\log P(\operatorname{mon} \mathrm{Hg})=-\frac{7100}{T(\mathrm{~K})}+5.05
$$

At $1500^{\circ} \mathrm{C}\left(2732^{\circ} \mathrm{F}\right)$ the vapor pressure of $\mathrm{V}_{2} \mathrm{O}_{5}$ is thus $1.46 \times 10^{-2}$ atmosphere (11.1 torr). In a high temperature environment such as the glass tank and glass tank regenerator, vanadium pentoxide is thought to be present only as vapor. $\mathrm{V}_{2} \mathrm{O}_{5}$ call also cause color changes in both glasses and refractories. Small amounts of $\mathrm{V}_{2} \mathrm{O}_{5}$ such as 0.1 wt \% will produce a distinct gray-green in refractories; ${ }^{8}$ this sometimes causes concern among furnace operators.

The combustion products as presented above will react with refractories and refractory insulations. The interactions of these combustion products and the refractory materials will be analyzed according to the composition system of the refractory material.

Fibrous refractory insulations including alumino-silicates, and alumina and zirconia as well as insulating fire brick will probably be much more susceptible to reaction and attack by alternate fuel combustion. products than the equivalent compositions in the form of a dense refractory. The much larger available surface area per unit mass in these insulations compared with dense refractory brick or a monolithic form 
would provide ready access for gaseous species to react with the refractory flbers or pore walls of the insulating brick. There is apparently no available experimental information regarding the structural stability of these thermal insulations in high-temperature atmospheres containing gaseous species of sodium, vanadium, and sulfur or of the effects of these interactions on the thermal transport properties of the thermal insulation materials.

\subsection{ALUMINOSILICATE SYSTEM}

The aluminosilicate family includes fireclay, high alumina, mullite, and corundum refractories. These are basically composed of alumina, silica, mullite, sillimanite, and silicate glass. The end members of the aluminosilicate series are silica and alumina. There are few industries operating processes above a few hundred degrees centigrade that do not make use of refractories of this family. As outlined by Chester, ${ }^{9}$ the application range of the aluminosilicate system in various fields is broad.

Vanadium pentoxide forms a low temperature eutectic $650^{\circ} \mathrm{C}\left(1202^{\circ} \mathrm{F}\right)$ with $\mathrm{Al}_{2} \mathrm{O}_{3}$. The phase diagram of the $\mathrm{V}_{2} \mathrm{O}_{5}-\mathrm{Al}_{2} \mathrm{O}_{3}$ system is presented in Figure 5.2. The intermediate compound is $\mathrm{Al}\left(\mathrm{VO}_{4}\right)$ which melts at $695^{\circ} \mathrm{C}$ $\left(1283^{\circ} \mathrm{F}\right)$. Therefore, if kinetics permit, $\mathrm{V}_{2} \mathrm{O}_{5}$. is a good flux for $\mathrm{Al}_{2} \mathrm{O}_{3}$. In comparison, the eutectic temperature of $\mathrm{V}_{2} \mathrm{O}_{5}$ and silica is $649^{\circ} \mathrm{C}$ $\left(1200^{\circ} \mathrm{F}\right)$ with no intermediate compound formation (Fig. 5.3). Vanadium pentoxide increases the crystallization, but not the nucleation rate of glass, and acts as a mineralizer enhancing the phase transformation of silica glass and quartz to cristobalite. ${ }^{10}$ If the work on the ternary system $\mathrm{V}_{2} \mathrm{O}_{5}-\mathrm{Al}_{2} \mathrm{O}_{3}-\mathrm{SiO}_{2}$ by Shimotakahara ${ }^{11}$ is reliable, a ternary compound $\left(\mathrm{V}_{2} \mathrm{O}_{5} \cdot \mathrm{Al}_{2} \mathrm{O}_{3} \cdot 2 \mathrm{SiO}_{2}\right)$, two ternary eutectics [mullite-ternary compound$\mathrm{V}_{2} \mathrm{O}_{5}, 657^{\circ} \mathrm{C}\left(1215^{\circ} \mathrm{F}\right)$, and silica-ternary compound $\left.-\mathrm{V}_{2} \mathrm{O}_{5}, 656^{\circ} \mathrm{C}\left(1213^{\circ} \mathrm{F}\right)\right]$ and one peritectic $\left[\mathrm{Al}_{2} \mathrm{O}_{3}-\operatorname{mullite}=\mathrm{V}_{2} \mathrm{O}_{5}, 657^{\circ} \mathrm{C}\left(1215^{\circ} \mathrm{F}\right)\right]$ are present.

The kinetics data for the interaction of $\mathrm{V}_{2} \mathrm{O}_{5}$ with $\mathrm{Al}_{2} \mathrm{O}_{3}$ or $\mathrm{SiO}_{2}$ are lacking and are even contradictory. Beer and Richarz ${ }^{12}$ examined the rate of $\mathrm{V}_{2} \mathrm{O}_{5}$ and $\mathrm{NaVO}_{3}$ attack in $\mathrm{Al}_{2} \mathrm{O}_{3}$. They concluded that at temperatures from $725^{\circ} \mathrm{C}\left(1337^{\circ} \mathrm{F}\right)$ to $870^{\circ} \mathrm{C}\left(1598^{\circ} \mathrm{F}\right)$, the rate of reaction is 


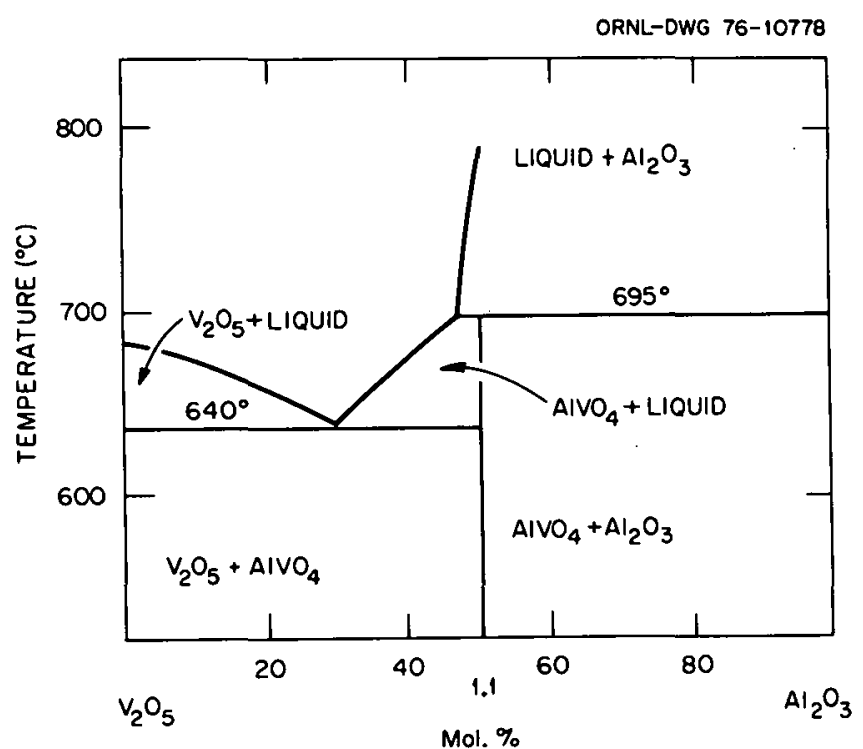

Fig. 5.2. Proposed Phase Diagram of the $\mathrm{V}_{2} \mathrm{O}_{5}-\mathrm{Al}_{2} \mathrm{O}_{3}$ System. Reprinted with permission from Phase Diagroms for Cercinists, E. M. Levin, C. R. Robbins, and H. F. McMurdie, eds., p. 124, American Ceramic Society, 1969.

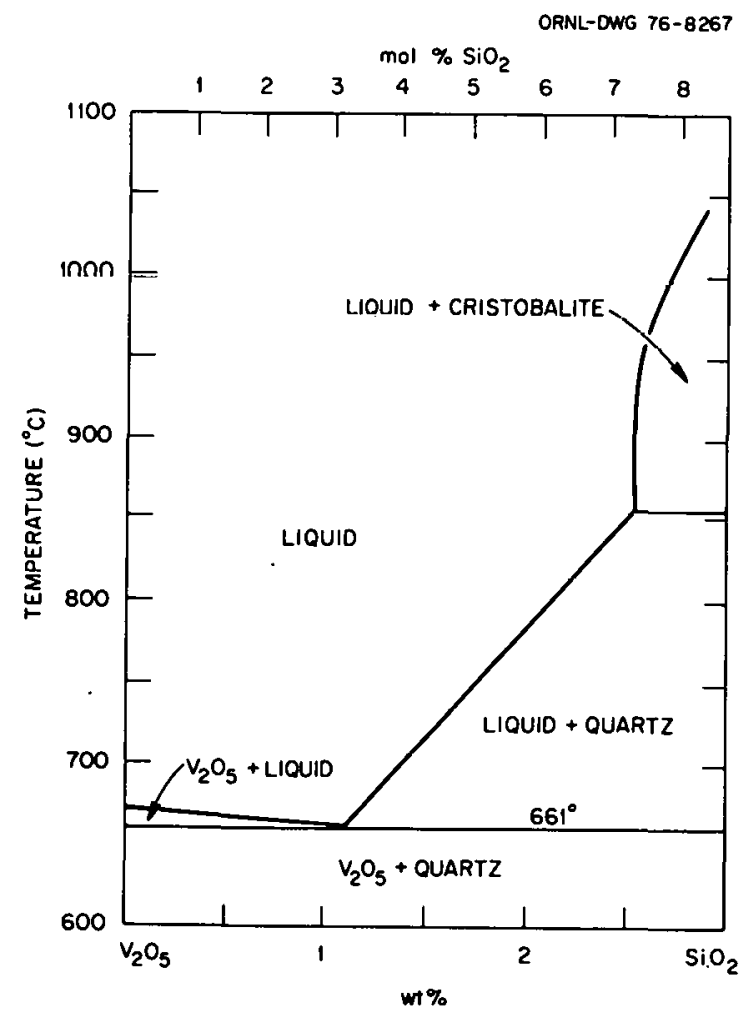

Fig. 5.3. Phase Diagram of the $\mathrm{V}_{2} \mathrm{O}_{5}-\mathrm{SiO}_{2}$ System. Reprinted with permission from Phase Diagroms for Cercomists, E. M. Levin, C. R. Robbins, and H. F. McMurdie, eds., 1969 Supplement, p. 110, American Ceramic Society, 1969. 
controlled by a chemical reaction with an activation energy of $40.9 \mathrm{kcal} / \mathrm{mole}$. From $870^{\circ} \mathrm{C}\left(1598^{\circ} \mathrm{F}\right)$ to $1300^{\circ} \mathrm{C}\left(2372^{\circ} \mathrm{F}\right)$, these authors report the reaction is diffusion controlled. For corrosion by $\mathrm{NaVO}_{3}$, the process is controlled by a chemical reaction with an activation energy of $45.5 \mathrm{kcal} / \mathrm{mole}$ at temperatures from $1000^{\circ} \mathrm{C}\left(1832^{\circ} \mathrm{F}\right)$ to $1275^{\circ} \mathrm{C}\left(2327^{\circ} \mathrm{F}\right)$. On the other hand, Frischat et al., ${ }^{13}$ investigated the dissolution of $\mathrm{Al}_{2} \mathrm{O}_{3}$ in $\mathrm{V}_{2} \mathrm{O}_{5}$ melts and observed a diffusion-controlled process below $850^{\circ} \mathrm{C}\left(1562^{\circ} \mathrm{F}\right)$.

The $\mathrm{Na}_{2} \mathrm{O}-\mathrm{Al}_{2} \mathrm{O}_{3}-\mathrm{SiO}_{2}$ s.ystem has been extensively examined. The ternary phase diagram gives the sodium silicates: $2 \mathrm{Na}_{2} \mathrm{O} \cdot \mathrm{SiO}_{2}, \mathrm{Na}_{2} \mathrm{O} \cdot \mathrm{SiO}_{2}$, and $\mathrm{Na}_{2} \mathrm{O} \cdot 2 \mathrm{SiO}_{2}$; two sodium aluminates: $\mathrm{Na}_{2} \mathrm{O} \cdot \mathrm{Al}_{2} \mathrm{O}_{3}$ and $\mathrm{B}$-alumina $\mathrm{Na}_{2} \mathrm{O} \cdot 1 \mathrm{Al}_{2} \mathrm{O}_{3}$; three ternary compounds: albite $\left(\mathrm{Na}_{2} \mathrm{O} \cdot \mathrm{Al}_{2} \mathrm{O}_{3} \cdot 6 \mathrm{SiO}_{2}\right)$, nepheline and its high temperature polymorph carnegieite $\left(\mathrm{Na}_{2} \mathrm{O} \cdot \mathrm{Al}_{2} \mathrm{O}_{3} \cdot 2 \mathrm{SiO}\right)$; two aluminum silicates: sillimanite $\left(\mathrm{Al}_{2} \mathrm{O}_{3} \cdot \mathrm{SiO} \mathrm{O}_{2}\right)$ and mullite $\left(3 \mathrm{Al}_{2} \mathrm{O}_{3} \cdot 2 \mathrm{SiO}\right)$ (Fig. 5.4). $\mathrm{Na}_{2} \mathrm{O}$ is a good glass network modifier and readily forms glasses with $\mathrm{Al}_{2} \mathrm{O}_{3}$ and $\mathrm{SiO}_{2}$. Upon exposure to $\mathrm{Na}_{2} \mathrm{O}$, the crystalline phases such as mullite $\left(3 \mathrm{Al}_{2} \mathrm{O}_{3} \cdot 2 \mathrm{SiO}_{2}\right)$, sillimanite $\left(\mathrm{Al}_{2} \mathrm{O}_{3} \cdot \mathrm{SiO}_{2}\right)$, and corundum, which are usually present in $\mathrm{Al}_{2} \mathrm{O}_{3}-\mathrm{SiO}_{2}$ refractories will form sodium aluminum silicates. The corrosion of mullite by $\mathrm{Na}_{2} \mathrm{CO}_{3}$ vapor was studied by Okawara and Yamaguchi. ${ }^{14}$ They report that mullite first decomposes into carnegieite and corundum. Corundum then gradually reacts to form sodium silicate and nepheline. Similarly, mullite exposed to sodium vanadate may decompose according to the following reactions:

$$
\begin{aligned}
& 3 \mathrm{Al}_{2} \mathrm{O}_{3} \cdot 2 \mathrm{SiO}_{2}+2 \mathrm{NaVO}_{3} \rightarrow \mathrm{Na}_{2} \mathrm{O} \cdot \mathrm{Al}_{2} \mathrm{O}_{3} \cdot 2 \mathrm{SiO}_{2}+2 \mathrm{Al}_{2} \mathrm{O}_{3}+\mathrm{V}_{2} \mathrm{O}_{5}, \\
& 11 / 3\left(3 \mathrm{Al}_{2} \mathrm{O}_{3} \cdot 2 \mathrm{SiO}_{2}\right)+2 \mathrm{NaVO}_{3} \rightarrow \mathrm{Na}_{2} \mathrm{O} \cdot 11 \mathrm{Al}_{2} \mathrm{O}_{3}+22 / 3 \mathrm{SiO}_{2}+\mathrm{V}_{2} \mathrm{O}_{5}, \text {, (5.9) } \\
& 3\left(3 \mathrm{Al}_{2} \mathrm{O}_{3} \cdot 2 \mathrm{SiO}_{2}\right)+2 \mathrm{NaVO}_{3}+\mathrm{Na}_{2} \mathrm{O} \cdot \mathrm{Al}_{2} \mathrm{O}_{3} \cdot 6 \mathrm{~S}_{1} \mathrm{O}_{2}+8 \mathrm{Al}_{2} \mathrm{O}_{3}+\mathrm{V}_{2} \mathrm{O}_{5},(5.10
\end{aligned}
$$

Unfortunatley, the standard free energies of formation for albite, nepheline, and $\beta$-alumina are presently unknown. It is thus uncertain that the above reactions are thermodynamically favorable. Since $\mathrm{NaVO}_{3}$ melts at temperatures lower than either $\mathrm{V}_{2} \mathrm{O}_{5}$ or $\mathrm{Na}_{2} \mathrm{O}$, mullite is expected 
$\mathrm{Na}_{2} \mathrm{O}-\mathrm{Al}_{2} \mathrm{O}_{3}-\mathrm{SiO}_{2}$

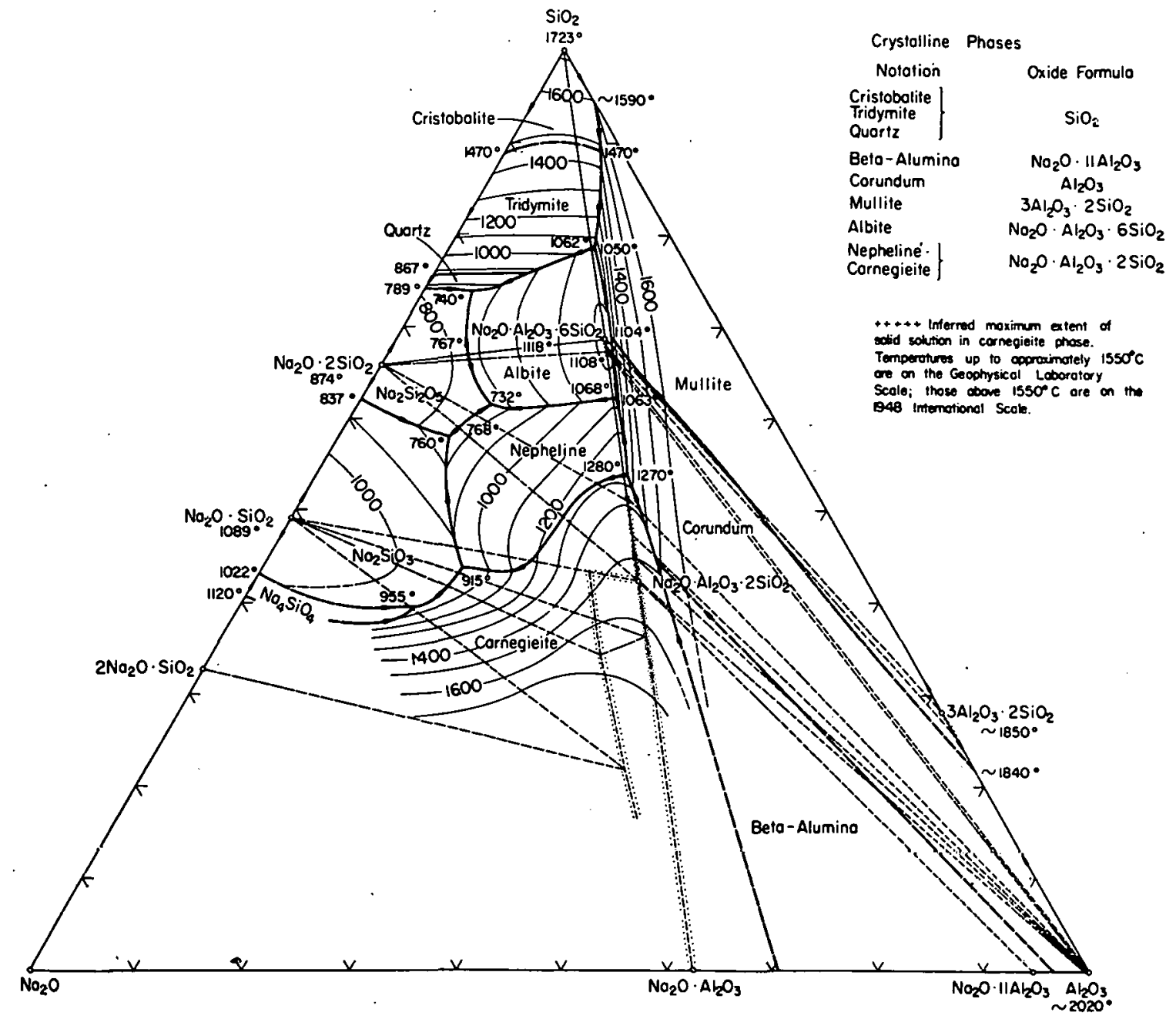

Fig. 5.4. Phase Diagram of the $\mathrm{Na}_{2} \mathrm{O}-\mathrm{Al}_{2} \mathrm{O}_{3}-\mathrm{SiO}_{2}$ System. Reprinted with permission from Phase Diagroms for Ceromists, E. M. Levin, C. R. Robbins, and H. F. McMurdie, eds., p. 181, American Ceramic Society, 1969 .

to decompose upon $\mathrm{NaVO}_{3}$ exposure at lower temperatures than in the case of $\mathrm{V}_{2} \mathrm{O}_{5}$ or $\mathrm{Na}_{2} \mathrm{O}$ exposure alone. In fact, the above reactions have been confirmed by experiments at temperatures higher than $900^{\circ} \mathrm{C}\left(1652^{\circ} \mathrm{F}\right) .^{15}$ Similarly, sillimanite and corundum may react with the combustion product $\mathrm{NaVO}_{3}$ as follows: 


$$
\begin{aligned}
& 2\left(\mathrm{Al}_{2} \mathrm{O}_{3} \cdot \mathrm{SiO}_{2}\right)+2 \mathrm{NaVO}_{3} \rightarrow \mathrm{Na}_{2} \mathrm{O} \cdot \mathrm{Al}_{2} \mathrm{O}_{3} \cdot 2 \mathrm{SiO}_{2}+\mathrm{Al}_{2} \mathrm{O}_{3}+2 \mathrm{~V}_{2} \mathrm{O}_{5}, \\
& 11\left(\mathrm{Al}_{2} \mathrm{O}_{3} \cdot \mathrm{SiO}_{2}\right)+24\left(\mathrm{NaVO}_{3}\right) \rightarrow \mathrm{Na}_{2} \mathrm{O} \cdot 11 \mathrm{Al}_{2} \mathrm{O}_{3}+11\left(\mathrm{Na}_{2} \mathrm{O} \cdot \mathrm{SiO}_{2}\right) \\
& +12 \mathrm{~V}_{2} \mathrm{O}_{5} \text {, } \\
& 1 \mathrm{Al}_{2} \mathrm{O}_{3}+2 \mathrm{NaVO}_{3} \rightarrow \mathrm{Na}_{2} \mathrm{O} \cdot 11 \mathrm{Al}_{2} \mathrm{O}_{3}+\mathrm{V}_{2} \mathrm{O}_{5}
\end{aligned}
$$

Rigby and Hutton ${ }^{15}$ found that, in the aluminosilicate refractory system, $\mathrm{Na}_{2} \mathrm{O}$ first reacts with $\mathrm{Al}_{2} \mathrm{O}_{3}$ and $\mathrm{SiO}_{2}$ to form sodium aluminate and sodium silicate. Mullite also starts to decompose and to form nepheline, sodium aluminate, and $\beta$-alumina. The final phase relations at equilibrium are calculated using the $\mathrm{Na}_{2} \mathrm{O}$ content, and the $\mathrm{Na}_{2} \mathrm{O}-$ $\mathrm{Al}_{2} \mathrm{O}_{3}-\mathrm{SiO}_{2}$ phase diagram (Fig. 5.4). Generally speaking, the fluxing effect of $\mathrm{Na}_{2} \mathrm{O}$ can be summarized (Table 5.2).

Vanadium pentoxide in the combustion ash will reduce the amount of free $\mathrm{Na}_{2} \mathrm{O}$ available to react directly with the refractory because the $\mathrm{V}_{2} \mathrm{O}_{5}$ reacts with $\mathrm{Na}_{2} \mathrm{O}$ to form sodium vanadate. However, sodium vanadate acting both as a flux and a mineralizer may react with the $\mathrm{Al}_{2} \mathrm{O}_{3}-\mathrm{SiO}_{2}$ compositions at much lower temperatures and generate more liquid phase than would either $\mathrm{Na}_{2} \mathrm{O}$ or $\mathrm{V}_{2} \mathrm{O}_{5}$ alone. Indeed, in the presence of both $\mathrm{Na}_{2} \mathrm{O}$ and $\mathrm{V}_{2} \mathrm{O}_{5}$, nepheline is formed at $800^{\circ} \mathrm{C}\left(1972^{\circ} \mathrm{F}\right)$, whereas it is not formed even at $900^{\circ} \mathrm{C}\left(1652^{\circ} \mathrm{F}\right)$ when $\mathrm{Na}_{2} \mathrm{O}$ alone is present. Albite, which also is not formed in the presence of $\mathrm{Na}_{2} \mathrm{O}$ alone, is formed if $\mathrm{NaVO}_{3}$ is present with $\mathrm{Na}_{2} \mathrm{O}$ because of the powerful mineralizer action of $\mathrm{NaVO}_{3}$. That the sodium vanadates are strong fluxing agents in the $\mathrm{Al}_{2} \mathrm{O}_{3}-\mathrm{SiO}_{2}$ system was observed by Rigby and Hutton, ${ }^{1.5}$ MacLaren and Richardson, 16 and Jones and Hardy. ${ }^{17}$ However, the total amount of $\mathrm{Na}_{2} \mathrm{O}$ and $\mathrm{V}_{2} \mathrm{O}_{5}$ used in these investigations all exceeded $10 \mathrm{wt} \%$, and were high compared to levels more typical of combustor concentrations. Busby ${ }^{18}$ conducted an experiment using samples containing lower concentrations of $\mathrm{V}_{2} \mathrm{O}_{5}$ and $\mathrm{Na}_{2} \mathrm{O}$ (less than $5 \%$ ). He concluded that the $2 \%$ of $\mathrm{Na}_{2} \mathrm{O}$ can cause a lowering of about $20^{\circ} \mathrm{C}\left(36^{\circ} \mathrm{F}\right)$ in the refractoriness (indicated qualitatively by the amount of liquid phase present) of silica and $43 \%-\mathrm{Al}_{2} \mathrm{O}_{3}$ bricks, but $2 \%$ of $\mathrm{V}_{2} \mathrm{O}_{5}$ probably only causes a reduction of a few degrees 
Table 5.2. Temperatures at Which Aluminosilicate Refractories are Fluxed by $\mathrm{Na}_{2} \mathrm{O}$, and $\mathrm{Na}_{2} \mathrm{O}+\mathrm{V}_{2} \mathrm{O}_{5}$

\begin{tabular}{|c|c|c|c|}
\hline \multicolumn{2}{|c|}{ Composition, wt \% } & \multicolumn{2}{|c|}{ Fluxing Temperature, ${ }^{\mathrm{a}}{ }^{\circ} \mathrm{C}$} \\
\hline Silica & Alumina & $\mathrm{Na}_{2} \mathrm{O}$ Alone $e^{\mathrm{b}}$ & $\mathrm{Na}_{2} \mathrm{O}+\mathrm{V}_{2} \mathrm{O}_{5} \mathrm{~b}$ \\
\hline 100 & 0 & 800 & 900 \\
\hline 80 & 20 & 800 & 900 \\
\hline 60 & 40 & 1000 & 900 \\
\hline 40 & 60 & 1400 & 1200 \\
\hline 20 & 80 & 1500 & 1300 \\
\hline 0 & 100 & 1600 & 1500 \\
\hline \multicolumn{4}{|c|}{$\begin{array}{l}a_{\text {The fluxing temperature means the temperature at }} \\
\text { which significant amounts of liquid phase are formed. } \\
\text { To ensure no liquid formation, the refractory should be } \\
\text { used at temperatures } 100^{\circ} \mathrm{C} \text { below the fluxing temperature. }\end{array}$} \\
\hline
\end{tabular}

centigrade. If the total amount of $\mathrm{V}_{2} \mathrm{O}_{5}$ is less than $0.5 \mathrm{wt} \%$, the lowering in the refractoriness of the $\mathrm{Al}_{2} \mathrm{O}_{3}-\mathrm{SiO}_{2}$ system is negligible. ${ }^{19}$

When silica refractories are subjected to fluxing by $\mathrm{Na}_{2} \mathrm{O}$, a glassy or amorphous phase will be formed in the composition range of $\mathrm{Na}_{2} \mathrm{O}$ less than 34 wt \%. Morsanyi ${ }^{20}$ found that vanadium pentoxide alone can cause the transformation of quartz to cristobalite. There was no apparent reaction between $\mathrm{V}_{2} \mathrm{O}_{5}$ and $\mathrm{SiO}_{2}$, under the conditions of these experiments. In contrast, $\mathrm{NaVO}_{3}$ fluxes $\mathrm{SiO}_{2}$ and produces a brownish-glass phase which contains about 2-5 wt \% $\mathrm{V}_{2} \mathrm{O}_{5}$. In addition to cristobalite, tridymite is also formed, with the formation of tridymite attributed to the presence of $\mathrm{Na}_{2} \mathrm{O}$. While $\mathrm{NaVO}_{3}$ reacts with high silica refractories, the result and products are essentially similar to those formed from silica by reaction with $\mathrm{Na}_{2} \mathrm{O}$. It thus seems from these investigations that $\mathrm{V}_{2} \mathrm{O}_{5}$ does not have a pronounced detrimental effect on silica refractories. Furthermore, $\mathrm{V}_{2} \mathrm{O}_{5}$ tends to increase the viscosity of the liquid phase formed by reaction at high temperatures of $\mathrm{Na}_{2} \mathrm{O}$ and silica. The increased viscosity will retard transport of sodium or vanadium 
species through this liquid phase and will make reaction of silica more difficult than with only $\mathrm{Na}_{2} \mathrm{O}$ and silica. This phenomenon also explains the very similar fluxing temperatures in 20\% alumina refractories under attack by $\mathrm{Na}_{2} \mathrm{O}-\mathrm{V}_{2} \mathrm{O}_{5}$ and $\mathrm{Na}_{2} \mathrm{O}$ (Table 5:2).

Plastic and castable refractories, which are widely used in monolithic forms generally contain bonding phases usually consisting of calcium aluminate cements such as $\mathrm{CaO} \cdot \mathrm{Al}_{2} \mathrm{O}_{3}, \mathrm{CaO} \cdot 2 \mathrm{Al}_{2} \mathrm{O}_{3}$, and $2 \mathrm{CaO} \cdot \mathrm{Al}_{2} \mathrm{O}_{3} \cdot \mathrm{SiO}_{2}$. The binary system $\mathrm{CaO}-\mathrm{V}_{2} \mathrm{O}_{5}$ has a series of eutectics and intermediate compounds (Fig. 5.5). The bonding phases in the

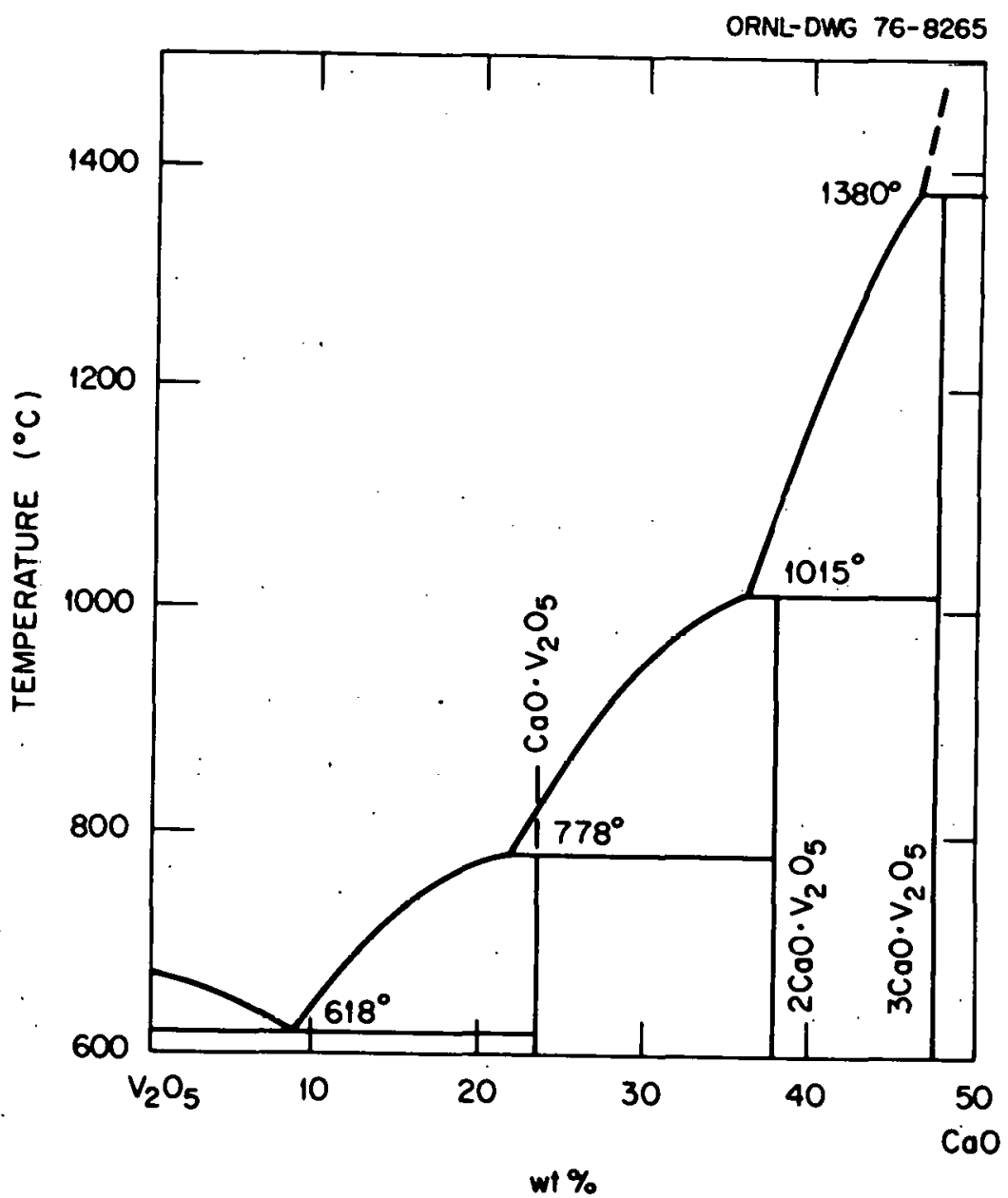

Fig. 5.5. Phase D1agram of the $\mathrm{V}_{2} \mathrm{O}_{5}-\mathrm{CaO}$ System. Reprinted with permission from Phase Diagrams for Ceramists, E. M. Levin, C. R. Robbins, and H. F. McMurdie, eds., p. 109, American Ceramic Society, 1964. 
monolithic refractories may react with the combustion product sodium vanadates as follows:

$$
\begin{aligned}
& 2\left(\mathrm{CaO} \cdot \mathrm{Al}_{2} \mathrm{O}_{3}\right)+2 \mathrm{NaVO}_{3} \rightarrow 2 \mathrm{CaO} \cdot \mathrm{V}_{2} \mathrm{O}_{5}+\mathrm{Na}_{2} \mathrm{O} \cdot \mathrm{Al}_{2} \mathrm{O}_{3}+\mathrm{Al}_{2} \mathrm{O}_{3} ; \\
& \Delta H_{29}^{\circ}=-21.15 \mathrm{kcal} / \mathrm{mole} \\
& 2\left(\mathrm{CaO} \cdot 2 \mathrm{Al}_{2} \mathrm{O}_{3}\right)+2 \mathrm{NaVO}_{3} \rightarrow 2 \mathrm{CaO} \cdot \mathrm{V}_{2} \mathrm{O}_{5}+\mathrm{Na}_{2} \mathrm{O} \cdot \mathrm{Al}_{2} \mathrm{O}_{3}+3 \mathrm{Al}_{2} \mathrm{O}_{3} ; \\
& \Delta H_{298}=-65.95 \mathrm{kcal} / \mathrm{mole} \\
& 4\left(2 \mathrm{CaO} \cdot \mathrm{Al}_{2} \mathrm{O}_{3} \cdot \mathrm{SiO}_{2}\right)+8 \mathrm{NaVO}_{3} \rightarrow 4\left(2 \mathrm{CaO} \cdot \mathrm{V}_{2} \mathrm{O}_{5}\right)+\mathrm{Na}_{2} \mathrm{O} \cdot \mathrm{Al}_{2} \mathrm{O}_{3} \cdot 4 \mathrm{SiO}_{2} \\
& +3\left(\mathrm{Na}_{2} \mathrm{O} \cdot \mathrm{Al}_{2} \mathrm{O}_{3}\right) \text {; } \\
& \Delta H_{298}^{\circ}=-43.4 \mathrm{kcal} / \mathrm{mole} \text {. }
\end{aligned}
$$

Since no gas phase is involved and the total number of moles of the reactants are approximately equal to the total number of moles of the products in these reactions, the standard enthalpy of reaction at $298 \mathrm{~K}\left(\Delta H_{298}^{\circ}\right)$ can be used as a reasonable indicator to determine if the reaction is thermodynamically favorable. The calculation of the standard enthalpy of reaction is based on the thermochemical data from various sources (Table 5.3). The negative values of these reactions indicate that they are thermodynamically favorable. Therefore, sodium vanadates will be expected to flux and react with calcium aluminates. The attack by sodium vanadate is expected to be more serious than for $\mathrm{Na}_{2} \mathrm{O}$ or $\mathrm{V}_{2} \mathrm{O}_{5}$ alone. Calcium oxide is known for resisting reaction and attack by $\mathrm{Na}_{2} 0 .{ }^{9}$ Vanadium pentoxide will flux calcium aluminate and $\mathrm{Na}_{2} \mathrm{O}$ can reduce the viscosity of the liquid phase formed; both actions will facilitate the further transport of vanadium through the liquid phase to the calcium aluminate interface and thereby favor more corrosion.

Phosphate bonded alumina refractories, which have a high strength at high temperatures and are widely used in many severe applications, probably will react more readily with the combustion product sodium vanadate than the corresponding alumina refractories. Phosphorous pentoxide forms low temperature eutectics and an intermediate compound 
Table 5.3. Selected Thermochemical Data for Some Refractory Materials

\begin{tabular}{|c|c|c|c|}
\hline Material & $\Delta \mathrm{H}_{298}^{\circ}$ & $\Delta S_{298}^{0}$ & Reference \\
\hline $\mathrm{V}_{2} \mathrm{O}_{5}$ & -370.65 & -0.105 & $\mathbf{a}$ \\
\hline $\mathrm{NaVO}_{3}$ & -273.75 & -0.0638 & a \\
\hline $\mathrm{Al}_{2} \mathrm{O}_{3} \quad(\alpha)$ & -400.4 & -0.0749 & $\mathrm{~b}$ \\
\hline $\mathrm{SiO}_{2}$ (quartz) & -217.2 & -0.436 & $\mathrm{~b}$ \\
\hline $3 \mathrm{Al}_{2} \mathrm{O}_{3} \cdot 2 \mathrm{SiO}_{2}$ & -1629.83 & -0.303 & $\mathrm{~b}$ \\
\hline $\mathrm{Al}_{2} \mathrm{O}_{3} \cdot \mathrm{SiO}_{2}$ & -618.81 & -0.118 & $\mathrm{~b}$ \\
\hline $\mathrm{Na}_{2} \mathrm{O} \cdot \mathrm{Al}_{2} \mathrm{O}_{3} \cdot 2 \mathrm{SiO}_{2}$ & - & & \\
\hline $\mathrm{Na}_{2} \mathrm{O} \cdot \mathrm{Al}_{2} \mathrm{O}_{3} \cdot 6 \mathrm{SiO}_{2}$ & & & \\
\hline $\mathrm{Na}_{2} \mathrm{O} \cdot 11 \mathrm{Al}_{2} \mathrm{O}_{3}$ & & & \\
\hline $\mathrm{Na}_{2} \mathrm{O} \cdot \mathrm{SiO}_{2}$ & -373.19 & -0.0754 & b \\
\hline $\mathrm{CaO} \cdot \mathrm{Al}_{2} \mathrm{O}_{3}$ & -555.2 & +0.0273 & c \\
\hline $\mathrm{CaO} \cdot 2 \mathrm{Al}_{2} \mathrm{O}_{3}$ & -954.6 & +0.0425 & c \\
\hline $2 \mathrm{CaO} \cdot \mathrm{Al}_{2} \mathrm{O}_{3} \cdot \mathrm{SiO}_{2}$ & -933.2 & +0.0430 & c \\
\hline $2 \mathrm{CaO} \cdot \mathrm{V}_{2} \mathrm{O}_{5} \quad\left(\mathrm{C}_{2} \mathrm{~V}\right)$ & -736.95 & -0.152 & a \\
\hline $3 \mathrm{CaO} \cdot \mathrm{V}_{2} \mathrm{O}_{5} \quad\left(\mathrm{C}_{3} \mathrm{~V}\right)$ & -902.95 & -0.174 & a \\
\hline $\mathrm{Na}_{2} \mathrm{O} \cdot \mathrm{Al}_{2} \mathrm{O}_{3}$ & -541.7 & -0.0513 & $\mathbf{b}$ \\
\hline $\mathrm{Na}_{2} \mathrm{O} \cdot \mathrm{Al}_{2} \mathrm{O}_{3} \cdot 4 \mathrm{SiO}$ & -1393.3 & & $\mathrm{~d}$ \\
\hline $2 \mathrm{CaO} \cdot \mathrm{SiO}_{2} \quad\left(\mathrm{C}_{2} \mathrm{~S}\right)$ & -539 & +0.0288 & $\mathrm{~d}$ \\
\hline $3 \mathrm{CaO} \cdot \mathrm{MgO} \cdot 2 \mathrm{SiO}_{2} \quad\left(\mathrm{C}_{3} \mathrm{MS}_{2}\right)$ & & & \\
\hline $\mathrm{CaO} \cdot \mathrm{MgO}^{\circ} \mathrm{S} \mathrm{O}_{2} \quad$ (CMS) & -539.9 & +0.0270 & d \\
\hline $2 \mathrm{MgO}^{\prime} \mathrm{SiO}_{2} \quad\left(\mathrm{M}_{2} \mathrm{~S}\right)$ & -520.30 & -0.0954 & $\mathrm{~b}$ \\
\hline $2 \mathrm{MgO}^{\cdot} \mathrm{V}_{2} \mathrm{O}_{5}$ & -677.75 & -0.153 & a \\
\hline $\mathrm{ZrSiO}_{4}$ & -483.736 & -0.0918 & $b$ \\
\hline $\mathrm{Na}_{2} \mathrm{ZrSiO}_{5}$ & & & \\
\hline $\mathrm{ZrV}_{2} \mathrm{O}_{7}$ & & & \\
\hline
\end{tabular}

a. D. Mah, Thermodynamic Properties of Vanadium and Its Compounds, RI-6727, Bureau of Mines, Washington, D. C. 1966.

b JANAF Thermochemical Tables, 2nd ed., NBS-37, National Bureau of Standards, Washington, D. C., 1971.

${ }^{c}$ Barin and Knacke, Thermochemical Properties of Inorganic Substance, Springer, New York, 1973.

dSelected Values of Chemical Thermodynomic Properties, NBS Cir. 500, National Bureau of Standards, Washington, D. C.., 1959. 
$\mathrm{P}_{2} \mathrm{O}_{5} \cdot \mathrm{V}_{2} \mathrm{O}_{5}$ with vanadium pentoxide. The bonding phase, aluminum phosphate, which has an excellent hot strength is therefore subject to potential degradation by vanadium compounds. Unfortunately, published data on phosphate bonded alumina refractories relevant to sodium and vanadium attack, such as phase diagrams and kinetics data, are lacking.

At lower temperatures $\left[1150^{\circ} \mathrm{C}\left(2102^{\circ} \mathrm{F}\right)\right]$ sulfidation can produce stable sulfates such as $\mathrm{Na}_{2} \mathrm{SO}_{4}$ and $\mathrm{MgSO}_{4}$. Their presence decreases the amount of free $\mathrm{Na}_{2} \mathrm{O}$ and sodium vanadate available for reactions in the $\mathrm{Al}_{2} \mathrm{O}_{3}-\mathrm{SiO}_{2}$ system. But, the sulfate may react directly with refractories with the evolution of $\mathrm{SO}_{3}$. The degradation in refractories due to the detrimental interaction between refractory oxides and sulfur combustion products is generally more serious than the case of sulfur-free combustion conditions. Formation of sulfates can cause a volume change and thus generate cracks in the refractory. These will lead to more surface area in the refractory to be exposed to the reacting species and also offer. faster transport paths for them into the refractory. Therefore, the net result of sulfate formation is probably enhanced refractory degradation.

\subsection{THE MAGNESIA-CHROME SYSTEM}

The basic refractory family including magnesite, magnesite-chrome, chrome-magnesite, and chrome has increased in its importance in recent years. The application is not only in the iron and steel industry, which requires the magnesia-chrome family in BOF and arc furnaces, but also from nonferrous metals, cement, and glass producers. The main advantage of this system is its excellent resistance to attack by iron oxide, alkali, and lime fluxes. But it is also well known for its poor thermal shock resistance. To a degree similar to the $\mathrm{Al}_{2} \mathrm{O}_{3}-\mathrm{SiO}_{2}$ system, the magnesia-chrome system has been investigated in its interactions with typical fuel combustion products.

Kerby and Wilson ${ }^{2}$ examined the systems $\mathrm{Na}_{2} \mathrm{O}-\mathrm{V}_{2} \mathrm{O}_{5}-\mathrm{Cr}_{2} \mathrm{O}_{3}$ and $\mathrm{Na}_{2} \mathrm{O}-\mathrm{V}_{2} \mathrm{O}_{5}-\mathrm{MgO}$ (Fig. 5.6 and 5.7). Dependence of phase equilibra on the oxygen partial pressure was not observed in the binary systems $\mathrm{Cr}_{2} \mathrm{O}_{3}-\mathrm{V}_{2} \mathrm{O}_{5}, \mathrm{Fe}_{2} \mathrm{O}_{3}-\mathrm{V}_{2} \mathrm{O}_{5}$, or $\mathrm{MgO}-\mathrm{V}_{2} \mathrm{O}_{5}$. Addition of $\mathrm{Na}_{2} \mathrm{O}$ results in a region of the liquidus temperatures, which is dependent upon the oxygen 


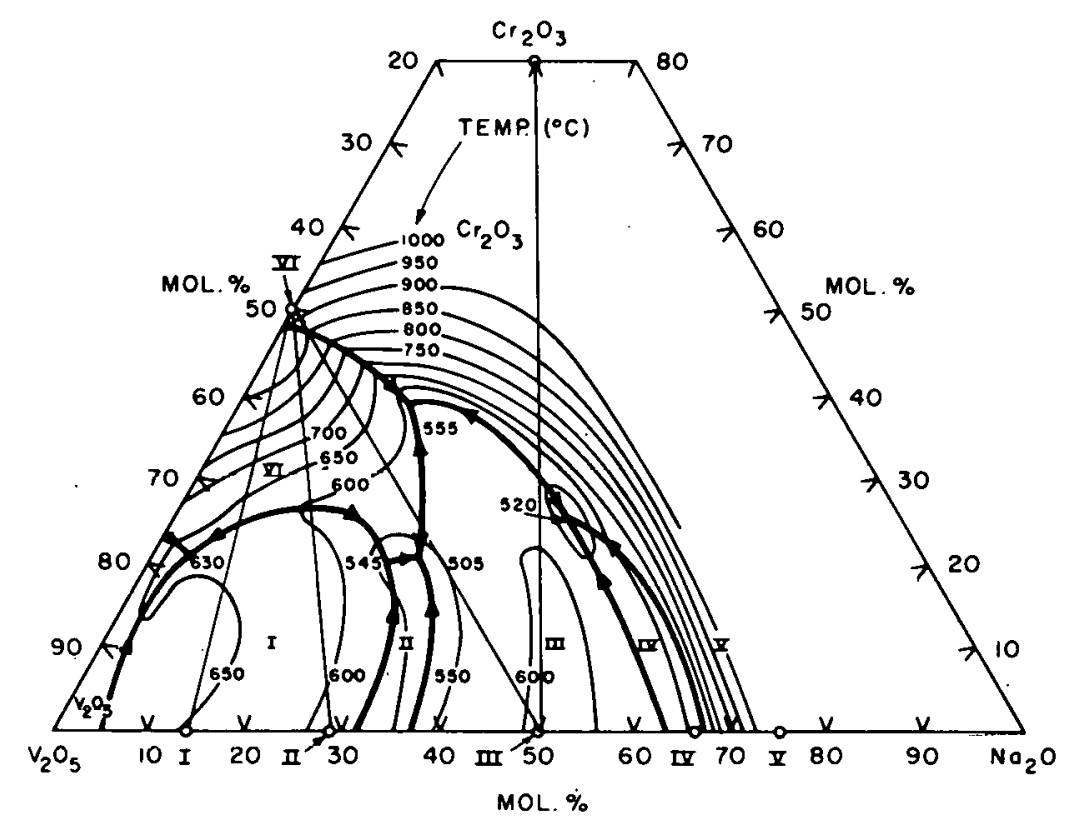

Fig. 5.6. Phase Diagram of the $\mathrm{V}_{2} \mathrm{O}_{5}-\mathrm{Na}_{2} \mathrm{O}-\mathrm{Cr}_{2} \mathrm{O}_{3}$ System. Binary phase compositions: I $=\mathrm{Na}_{2} \mathrm{O} \cdot 6 \mathrm{~V}_{2} \mathrm{O}_{5}$, II $=5 \mathrm{Na}_{2} \mathrm{O} \cdot 12 \mathrm{~V}_{2} \mathrm{O}_{5}$, III $=\mathrm{NaVO}_{3}$, IV $=\mathrm{Na}_{4} \mathrm{~V}_{2} \mathrm{O}_{7}, \mathrm{~V}=\mathrm{Na}_{3} \mathrm{VO}_{4}, \mathrm{VI}=\mathrm{CrVO}_{4}$. Reprinted with permission from R. C. Kerby and J. R. Wilson, Can. J. Chem. 51: 1037 (1973).

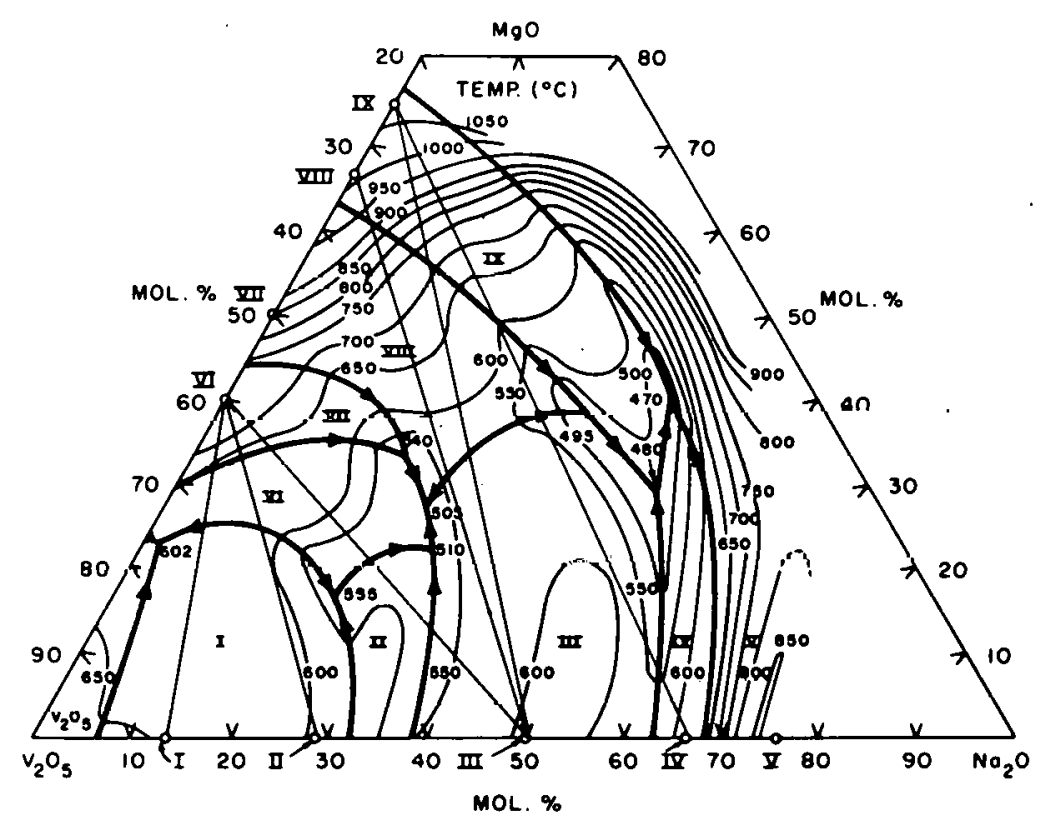

Fig. 5.7. Phase Diagram of the $\mathrm{V}_{2} \mathrm{O}_{5}-\mathrm{Na}_{2} \mathrm{O}-\mathrm{MgO}$ System. Binary phase compositions: I $=\mathrm{Na}_{2} \mathrm{O} \cdot 6 \mathrm{~V}_{2} \mathrm{O}_{5}$, II $=5 \mathrm{Na}_{2} \mathrm{O} \cdot 1.2 \mathrm{~V}_{2} \mathrm{O}_{5}$, III $=\mathrm{NaVO}_{3}$, IV $=$ $\mathrm{Na}_{4} \mathrm{~V}_{2} \mathrm{O}_{7}, \mathrm{~V}=\mathrm{Na}_{3} \mathrm{VO}_{4}$, VI $=\mathrm{Mg}_{2} \mathrm{~V}_{6} \mathrm{O}_{17}$, VII $=\mathrm{MgV}_{2} \mathrm{O}_{6}$, VIII $=\mathrm{Mg}_{2} \mathrm{~V}_{2} \mathrm{O}_{7}$, $\mathrm{IX}=\mathrm{Mg}_{3}\left(\mathrm{VO}_{4}\right)_{2}$. Reprinted with permission from R. C. Kerby and J. R. Wilson, Can. J. Chem. 51: 1039 (1973). 
partial pressure. The phase diagrams for $\mathrm{V}_{2} \mathrm{O}_{5}-\mathrm{Cr}_{2} \mathrm{O}_{5}$ and $\mathrm{V}_{2} \mathrm{O}_{5}-\mathrm{MgO}$ are shown in Figs. 5.8 and 5.9. The compound $\mathrm{CrVO}_{4}$ is formed; the eutectic temperature is $655^{\circ} \mathrm{C}\left(1211^{\circ} \mathrm{F}\right)$. Interactions with $\mathrm{Na}_{2} \mathrm{O}$ will produce several compounds and eutectics with the lowest eutectic temperature being $505^{\circ} \mathrm{C}\left(941^{\circ} \mathrm{F}\right)$ (Table 5.4). The system $\mathrm{MgO}-\mathrm{V}_{2} \mathrm{O}_{5}$ has four compounds and several peritectics and one eutectic with a temperature of $604^{\circ} \mathrm{C}\left(1119^{\circ} \mathrm{F}\right)$. The inclusion of $\mathrm{Na}_{2} \mathrm{O}$ results in several compounds, one eutectic, and four peritectics with the lowest one at $470^{\circ} \mathrm{C}\left(878^{\circ} \mathrm{F}\right)$. These phase diagrams show that sodium vanadate is a strong flux for the magnesia-chrome system. Basic refractories in general are resistant to reaction with alkalies. Chromia will react and form alkali chromates, but most often it is the bonding phase that is degraded in these refractories. Vanadium pentoxide will flux the magnesia-chrome system. The presence of $\mathrm{Na}_{2} \mathrm{O}$ will increase the fluidity of the liquid phase generated by vanadium pentoxide. This will enhance the solubility of the refractory in the slag and the transport rate of vanadium through the melt as we11. Therefore, the corrosion from a mixture of $\mathrm{Na}_{2} \mathrm{O}$ and $\mathrm{V}_{2} \mathrm{O}_{5}$ in this refractory system is far more serious than from either $\mathrm{V}_{2} \mathrm{O}_{5}$ or $\mathrm{Na}_{2} \mathrm{O}$ alone.

Since $\mathrm{CaO}$ is usually present in the bonding phase in the magnesiachrome refractory, attention should also be paid to the $\mathrm{CaO}-\mathrm{V}_{2} \mathrm{O}_{5}$ and related systems. The phase diagram of the syscem $C_{d O}=V_{2} O_{5}$ (Fig. 5.5) indicates the formation of three intermediate compounds, $\mathrm{CaO}-\mathrm{V}_{2} \mathrm{O}_{5}$, $2 \mathrm{CaO} \cdot \mathrm{V}_{2} \mathrm{O}_{5}$, and $3 \mathrm{CaO} \cdot \mathrm{V}_{2} \mathrm{O}_{5}$ with an eutectic point at $618^{\circ} \mathrm{C}\left(1144^{\circ} \mathrm{F}\right)$. The ternary system $\mathrm{CaO}-\mathrm{MgO}-\mathrm{SiO}_{2}$ has been investigated extensively (Fig. 5.10). For $\mathrm{V}_{2} \mathrm{O}_{5}$ exposure, the following reactions have been considered. The symbols used in these equations are indicated in Table 5.3.

$$
\begin{aligned}
& \mathrm{MgO}+2 \mathrm{C}_{2} \mathrm{~S}+1 / 3 \mathrm{~V}_{2} \mathrm{O}_{5} \rightarrow \mathrm{C}_{3} \mathrm{MS}_{2}+1 / 3 \mathrm{C}_{3} \mathrm{~V} \quad \Delta H_{298}^{\circ}=-22.83 \mathrm{kcal} / \mathrm{mole}(5.17) \\
& \mathrm{MgO}+\mathrm{C}_{3} \mathrm{MS}_{2}+1 / 3 \mathrm{~V}_{2} \mathrm{O}_{5} \rightarrow 2 \mathrm{CMS}+1 / 3 \mathrm{C}_{3} \mathrm{~V} \quad \Delta H_{298}^{\circ}=-22.20 \mathrm{kcal} / \mathrm{mole}(5.18) \\
& \mathrm{MgO}+\mathrm{CMS}+1 / 3 \mathrm{~V}_{2} \mathrm{O}_{5} \rightarrow \mathrm{M}_{2} \mathrm{~S}+1 / 3 \mathrm{C}_{3} \mathrm{~V} \quad \Delta H_{298}^{\circ}=-13.1 \mathrm{kcal} / \mathrm{mole}
\end{aligned}
$$




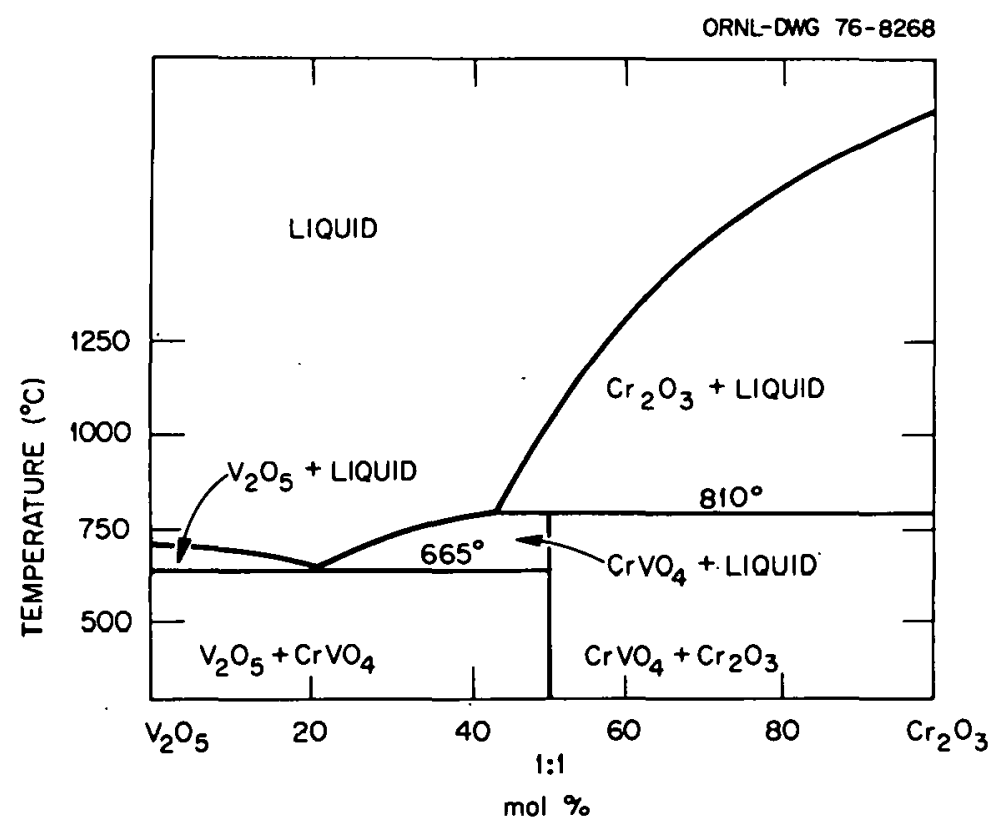

Fig. 5.8. Phase Diagram of the $\mathrm{V}_{2} \mathrm{O}_{5}-\mathrm{Cr}_{2} \mathrm{O}_{3}$ System. Reprinted with permission from Phase Diagrams for Ceromists, E. M. Levin, C. R. Robbins, and H. F. McMurdie, eds., p. 130, American Ceramic Society, 1964.

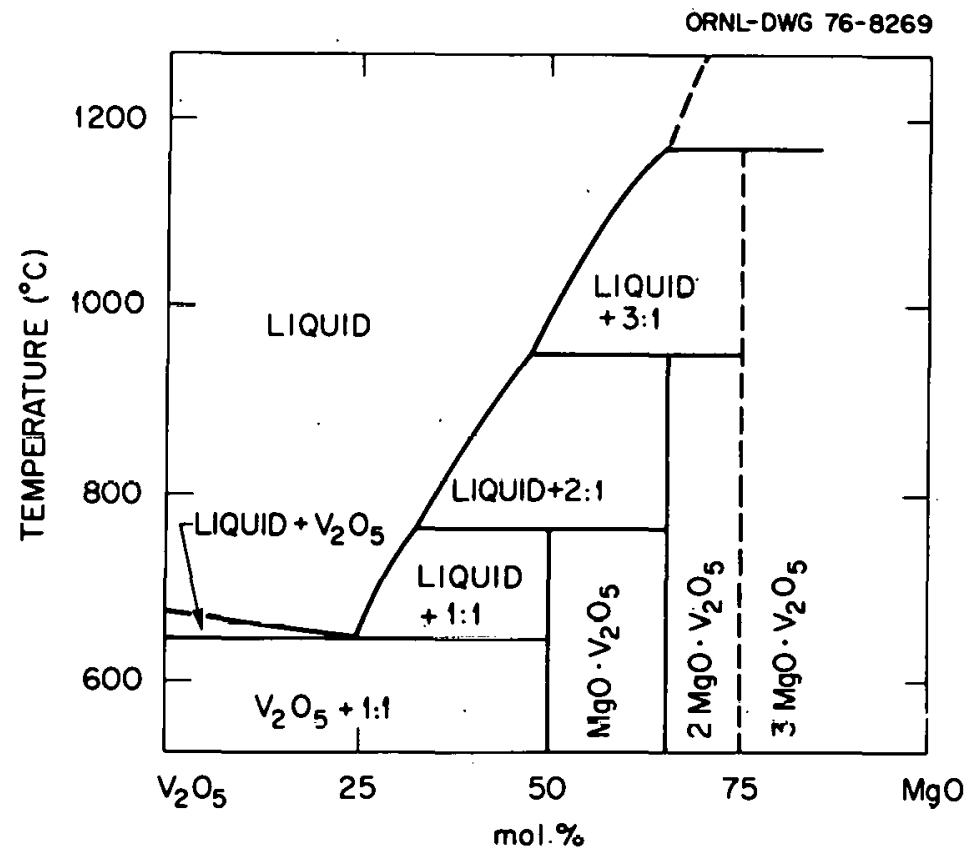

Fig. 5.9. Phase Diagram of the $\mathrm{V}_{2} \mathrm{O}_{5}-\mathrm{MgO}$ System. Reprinted with permission from Phase Diagrams for Cerramists, E. M. Levin, C. R. Robbins, and H. F. McMurdie, eds., 1969 Supplement, p. 89, American Ceramic Society, 1969. 
Table 5.4. Invariant Points in the Systems $\mathrm{V}_{2} \mathrm{O}_{5}-\mathrm{Cr}_{2} \mathrm{O}_{3}, \mathrm{~V}_{2} \mathrm{O}_{5}-\mathrm{Na}_{2} \mathrm{O}-\mathrm{Cr}_{2} \mathrm{O}_{3}$, $\mathrm{V}_{2} \mathrm{O}_{5}-\mathrm{MgO}, \mathrm{V}_{2} \mathrm{O}_{5}-\mathrm{Na}_{2} \mathrm{O}-\mathrm{MgO}, \mathrm{V}_{2} \mathrm{O}_{5}-\mathrm{CaO}, \mathrm{V}_{2} \mathrm{O}_{5}-\mathrm{SiO}_{2}, \mathrm{~V}_{2} \mathrm{O}_{5}-\mathrm{Al}_{2} \mathrm{O}_{3}, \mathrm{~V}_{2} \mathrm{O}_{5}-\mathrm{ZrO}_{2}$

\begin{tabular}{|c|c|c|c|c|c|}
\hline \multicolumn{3}{|c|}{$\begin{array}{c}\text { Composition } \\
\text { (mole } \mathrm{z})\end{array}$} & \multirow[t]{2}{*}{$\begin{array}{c}\text { Temperature } \\
\left({ }^{\circ} \mathrm{C}\right)\end{array}$} & \multirow[t]{2}{*}{ Type of Invartant } & \multirow[t]{2}{*}{ Equilibrium Sol id Phases } \\
\hline$v_{2} O_{5}$ & $\mathrm{Cr}_{2} \mathrm{O}_{3}$ & & & & \\
\hline 76 & 24 & & 655 & Eutectic & $\mathrm{V}_{2} \mathrm{O}_{5}+\mathrm{CrVO}_{4}$ \\
\hline 52 & 48 & & 902 & Peritectic & $\mathrm{CrVO}_{4}+\mathrm{Cr}_{2} \mathrm{O}_{3}$ \\
\hline $\mathrm{V}_{2} \mathrm{O}_{5}$ & $\mathrm{Na}_{\mathbf{2}} \mathrm{O}$ & $\mathrm{Cr}_{2} \mathrm{O}_{3}$ & & & \\
\hline 76 & 3 & 21 & 630 & Eutectic & $\mathrm{V}_{2} \mathrm{O}_{5}+\mathrm{Na}_{2} \mathrm{O} \cdot \mathrm{xV}_{2} \mathrm{O}_{4} \cdot(6-x) \mathrm{V}_{2} \mathrm{O}_{5}+\mathrm{CrVO}_{4}$ \\
\hline 56 & 26 & 18 & 545 & Peritectic & $\mathrm{Na}_{2} \mathrm{O} \cdot \mathrm{xV}_{2} \mathrm{O}_{4} \cdot(6-x) \mathrm{V}_{2} \mathrm{O}_{5}+\mathrm{CrVO}_{4}+5 \mathrm{Na}_{2} \mathrm{O} \cdot \mathrm{xV}_{2} \mathrm{O}_{4} \cdot(12-x) \mathrm{V}_{2} \mathrm{O}_{5}$ \\
\hline 52 & 28 & 20 & 505 & Eutectic & $5 \mathrm{Na}_{2} \mathrm{O} \cdot \mathrm{xv}_{2} \mathrm{O}_{4} \cdot(12-x) \mathrm{V}_{2} \mathrm{O}_{5}+\mathrm{NaVO}_{3}+\mathrm{CrVO}_{4}$ \\
\hline 43 & 17 & 40 & 555 & Eutectic & $\mathrm{CrVO}_{4}+\mathrm{NaVO}_{3}+\mathrm{Cr}_{2} \mathrm{O}_{3}$ \\
\hline 35 & 39 & 26 & 520 & Eutectic & $\mathrm{NaVO}_{3}+\mathrm{Na}_{4} \mathrm{~V}_{2} \mathrm{O}_{7}+\mathrm{Cr}_{2} \mathrm{O}_{3}$ \\
\hline$v_{2} O_{5}$ & $\mathrm{MgO}$ & & . & & 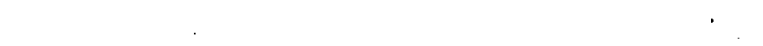 \\
\hline 77 & 23 & & 604 & Eutectic & $\mathrm{V}_{2} \mathrm{O}_{5}+\mathrm{Mg}_{2} \mathrm{~V}_{6} \mathrm{O}_{17}$ \\
\hline 72 & 28 & & 640 & Peritectic & $\mathrm{Mg}_{2} \mathrm{~V}_{6} \mathrm{O}_{1},+\mathrm{Mg}_{2} \mathrm{O}_{6}$ \\
\hline 56 & 44 & & 742 & Peritectic & $\mathrm{MgV}_{2} \mathrm{O}_{6}+\mathrm{Mg}_{2} \mathrm{~V}_{2} \mathrm{O}_{7}$ \\
\hline 37 & 63 & & 980 & Peritectic & $\mathrm{MB}_{2} \mathrm{~V}_{2} \mathrm{O}_{7}+\mathrm{Mg}_{3}\left(\mathrm{VO}_{4}\right)_{2}$ \\
\hline $\mathrm{v}_{2} \mathrm{O}_{\mathrm{s}}$ & $\mathrm{Na}_{2} \mathrm{O}$ & $\mathrm{MgO}$ & $\cdot$ & & \\
\hline 77 & 1. & 22 & 602 & Eutectic & $\mathrm{V}_{2} \mathrm{O}_{5}+\mathrm{Mg}_{2} \mathrm{~V}_{6} \mathrm{O}_{37}+\mathrm{Na}_{2} \mathrm{O} \cdot \mathrm{xV}_{2} \mathrm{O}_{4} \cdot(6-x) \mathrm{V}_{2} \mathrm{O}_{5}$ \\
\hline 61 & 23 & 16 & 535 & Peritectic & $\mathrm{Na}_{2} \mathrm{O} \cdot \mathrm{xV}_{2} \mathrm{O}_{4} \cdot(6-x) \mathrm{V}_{2} \mathrm{O}_{5}+5 \mathrm{Na}_{2} \mathrm{O} \cdot \mathrm{xV}_{2} \mathrm{O}_{4} \cdot(12-x) \mathrm{V}_{2} \mathrm{O}_{5}+\mathrm{Mg}_{2} \mathrm{~V}_{6} \mathrm{O}_{17}$ \\
\hline 49 & 30 & 21 & 510 & Peritectic & $\mathrm{Mg}_{2} \mathrm{~V}_{6} \mathrm{O}_{17}+\mathrm{NaVO}_{3}+5 \mathrm{Na}_{2} \mathrm{O} \cdot \mathrm{xV}_{2} \mathrm{O}_{4} \cdot(12-x) \mathrm{V}_{2} \mathrm{O}_{5}$ \\
\hline 46 & 21 & 33 & 540 & Peritectic & $\mathrm{Mg}_{2} \mathrm{~V}_{6} \mathrm{O}_{17}+\mathrm{Mg}_{2} \mathrm{~V}_{2} \mathrm{O}_{7}+\mathrm{MgV}_{2} \mathrm{O}_{6}$ \\
\hline 47 & $\underline{26}$ & 27 & 505 & Eutest1c & $\mathrm{NaVO}++\mathrm{Mg}_{2} \mathrm{~V}_{9} \mathrm{O}_{17}+\mathrm{Mg}_{7} \mathrm{~V}_{2} \mathrm{O}_{7}$ \\
\hline 24 & 37 & 39 & 495 & Peritectic. & $\mathrm{NaVn},+\mathrm{MB}_{9}\left(\mathrm{VO}_{4}\right)_{2}+\mathrm{Mg}_{2} \mathrm{~V}_{2} \mathrm{O}_{7}$ \\
\hline 15 & 44 & 41 & 470 & Penitectic & $\mathrm{Mg}_{3}\left(\mathrm{VO}_{4}\right)_{2}+\mathrm{Na}_{4} \mathrm{~V}_{2} \mathrm{O}_{7}$ \\
\hline 22 & 48 & 30 & 480 & Peritectic & $\mathrm{MB}_{3}\left(\mathrm{VO}_{4}\right)_{2}+\mathrm{Na}_{4} \mathrm{~V}_{2} \mathrm{O}_{7}+\mathrm{NaVO}_{3}$ \\
\hline $\mathrm{v}_{2} \mathrm{O}_{5}$ & $\mathrm{CaO}$ & & & & \\
\hline 78 & 22 & & 618 & Eutectic & $\mathrm{CaO} \cdot \mathrm{V}_{2} \mathrm{O}_{5}$ \\
\hline 58 & 42 & & 778 & Peritectic & $2 \mathrm{CaO} \cdot \mathrm{V}_{2} \mathrm{O}_{5}$ \\
\hline 36 & 64 & & 1015 & Peritectic & $3 \mathrm{CaO} \cdot \mathrm{v}_{2} \mathrm{O}_{5}$ \\
\hline $\mathrm{V}_{2} \mathrm{O}_{5}$ & $\mathrm{SiO}_{2}$ & & & & \\
\hline 96.7 & 3.3 & & 661 & Eutectic & none \\
\hline $\mathrm{v}_{2} \mathrm{O}_{5}$ & $\mathrm{Al}_{2} \mathrm{O}_{3}$ & & & . & \\
\hline 98.4 & 1.6 & & 640 & Eutect1c & $\mathrm{AlVO}_{4}$ \\
\hline $\mathrm{V}_{2} \mathrm{O}_{5}$ & $2 \mathrm{rO}_{2}$ & & & & \\
\hline 80 & 20 & & 650 & Eutect1c & $\mathrm{Z}_{2} \mathrm{~V}_{2} \mathrm{O}$ \\
\hline
\end{tabular}




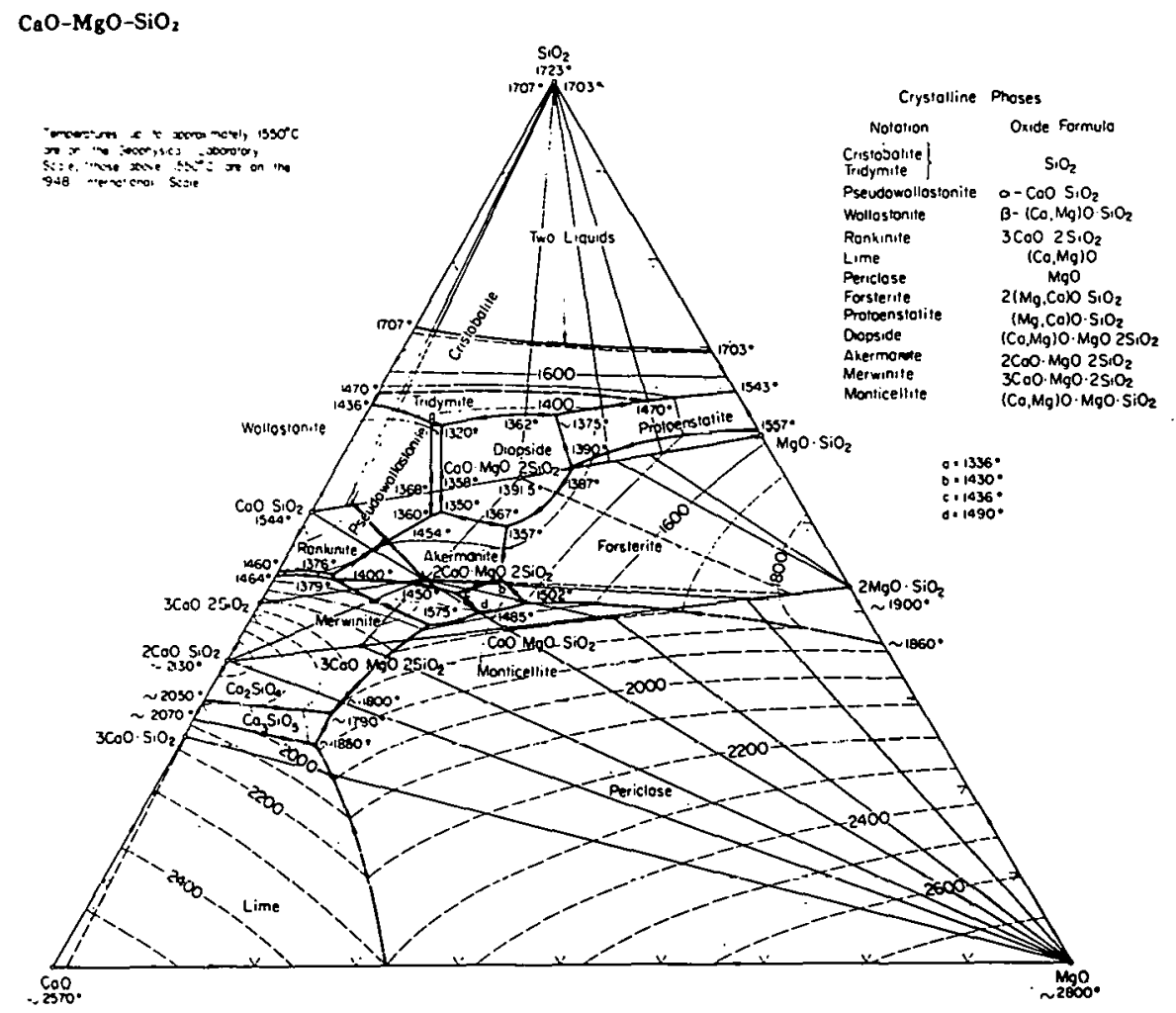

Fig. 5.10. Phase Diagram of the CaO-MgO-SiO 2 System. Reprinted with permission from Phase Diagroms for Cercomists, E. M. Levin, C. R. Robbins, and H. F. McMurdie, eds., p. 210, American Ceramic Society, 1964.

Therefore, the existence of forsterite $\mathrm{M}_{2} \mathrm{~S}$ was predicted and indeed was confirmed at $1450^{\circ} \mathrm{C}\left(2642^{\circ} \mathrm{F}\right)$ by Eke and Brett. 21 They also discovered a solid solution phase of $\mathrm{C}_{2} \mathrm{~S}$ and $\mathrm{C}_{3} \mathrm{~V},\left(\mathrm{CaO}_{2.5} \mathrm{SiO}_{2}\left(\mathrm{~V}_{2} \mathrm{O}_{5}\right)_{0.2}\right.$ and a phase field of $\mathrm{MgO}, \mathrm{M}_{2} \mathrm{~S}$, and liquid at $1500^{\circ} \mathrm{C}\left(2732^{\circ} \mathrm{F}\right)$ and $1450^{\circ} \mathrm{C}\left(2642^{\circ} \mathrm{F}\right) .{ }^{22}$ The presence of forsterite in high lime compositions indicate stability of forsterite relative to $\mathrm{C}_{2} \mathrm{~S}$ upon $\mathrm{V}_{2} \mathrm{O}_{5}$ exposure.

The presence of $\mathrm{V}_{2} \mathrm{O}_{5}$ will increase the amount of the liquid phase in the psuedo-ternary system $\mathrm{CaO}-\mathrm{MgO}_{\mathrm{SiO}}$, which becomes glass upon quenching. Dicalcium silicate and $\mathrm{C}_{3} \mathrm{MS}_{2}$ will be converted by $\mathrm{V}_{2} \mathrm{O}_{5}$ to liquids at $1450^{\circ} \mathrm{C}\left(2642^{\circ} \mathrm{F}\right)$. The liquid phase between grains will lead to grain growth, reduction in hot strength, and consequent failure of the refractory. For magnesite bricks containing forsterite with low lime content, the forsterite will act as a stable second phase that will limit the 
liquid penetration and the grain growth, and will promote bonding of the grains.

The corrosion resulting from both $\mathrm{V}_{2} \mathrm{O}_{5}$ and $\mathrm{Na}_{2} \mathrm{O}$ together in the basic refractory will be more serious than for $\mathrm{V}_{2} \mathrm{O}_{5}$ alone. The sodium oxide may attack the bonding phase to form glassy phases since the $\mathrm{V}_{2} \mathrm{O}_{5}-\mathrm{CaO}-\mathrm{SiO}_{2}$ system has large compositional ranges in which glasses are formed. The presence of $\mathrm{V}_{2} \mathrm{O}_{5}$ somehow reduces this tendency, perhaps by the increased viscosity in the liquid phase. ${ }^{20}$ Sodium vanadate may react with $2 \mathrm{CaO} \cdot \mathrm{SiO}_{2}, \mathrm{CaO} \cdot \mathrm{MgO} \cdot \mathrm{SiO}_{2}$, and $2 \mathrm{CaO} \cdot \mathrm{Al}_{2} \mathrm{O}_{3} \cdot \mathrm{SiO}_{2}$ according to the reactions as follows:

$$
\begin{gathered}
2 \mathrm{NaVO}_{3}+2 \mathrm{CaO} \cdot \mathrm{SiO}_{2} \rightarrow \\
2 \mathrm{CaO} \cdot \mathrm{V}_{2} \mathrm{O}_{5}+\mathrm{Na}_{2} \mathrm{O} \cdot \mathrm{SiO}_{2} ; \\
\Delta H_{298}^{\circ}=-23.65 \mathrm{kcal} / \mathrm{mole} \\
4 \mathrm{NaVO}_{3}+2\left(\mathrm{CaO} \cdot \mathrm{MgO} \cdot \mathrm{SiO}_{2}\right) \rightarrow 2 \mathrm{CaO} \cdot \mathrm{V}_{2} \mathrm{O}_{5}+2 \mathrm{MgO} \cdot \mathrm{V}_{2} \mathrm{O}_{5}+2\left(\mathrm{Na}_{2} \mathrm{O} \cdot \mathrm{SiO}_{2}\right) ; \\
\Delta H_{298}^{\circ}=-13.18 \mathrm{kcal} / \mathrm{mole} \\
2 \mathrm{NaVO}_{3}+2 \mathrm{CaO} \cdot \mathrm{Al}_{2} \mathrm{O}_{3} \cdot \mathrm{SiO}_{2} \rightarrow 2 \mathrm{CaO} \cdot \mathrm{V}_{2} \mathrm{O}_{5}+\mathrm{Na}_{2} \mathrm{O} \cdot \mathrm{SiO}_{2}+\mathrm{Al}_{2} \mathrm{O}_{3} ; \\
\Delta H_{298}^{\circ}=-29.84 \mathrm{kcal} / \mathrm{mole}_{9}
\end{gathered}
$$

The calculation of the standard enthalpy of formation indicates that $2 \mathrm{CaO} \cdot \mathrm{SiO}_{2}$ and $2 \mathrm{CaO} \cdot \mathrm{Al}_{2} \mathrm{O}_{3} \cdot \mathrm{SiO}_{2}$ will be decomposed by sodium vanadates. In comparison, if only $\mathrm{V}_{2} \mathrm{O}_{5}$ is present, the following reactions may be considered:

$$
\begin{array}{r}
\mathrm{V}_{2} \mathrm{O}_{5}+2 \mathrm{CaO} \cdot \mathrm{SiO}_{2} \rightarrow 2 \mathrm{CaO} \cdot \mathrm{V}_{2} \mathrm{O}_{5}+\mathrm{SiO}_{2} ; \\
\Delta H_{298}^{\circ}=-32.3 \mathrm{kcal} / \mathrm{mole} \\
2 \mathrm{~V}_{2} \mathrm{O}_{5}+2\left(\mathrm{CaO} \cdot \mathrm{MgO} \cdot \mathrm{SiO}_{2}\right) \rightarrow 2 \mathrm{CaO} \cdot \mathrm{V}_{2} \mathrm{O}_{5}+2 \mathrm{MgO} \cdot \mathrm{V}_{2} \mathrm{O}_{5}+2 \mathrm{SiO}_{2} \\
\Delta H_{298}^{\circ}=-3.6 \mathrm{kcal} / \mathrm{mole}
\end{array}
$$




$$
\begin{aligned}
\mathrm{V}_{2} \mathrm{O}_{5}+2 \mathrm{CaO} \cdot \mathrm{Al}_{2 .} \mathrm{O}_{3} \cdot \mathrm{SiO}_{2} \rightarrow 2 \mathrm{CaO} \cdot \mathrm{V}_{2} \mathrm{O}_{5}+\mathrm{Al}_{2} \mathrm{O}_{3}+\mathrm{SiO}_{2} ; \\
\Delta H_{298}^{\circ}=-38.5 \mathrm{kcal} / \mathrm{mole} .
\end{aligned}
$$

The negative values of the standard enthalpy of reaction indicate that all these reactions are thermodynamically favorable. Again, as described before, the presence of $\mathrm{Na}_{2} \mathrm{O}$ will render the liquid phase less viscous and increase the solubility of the bonding phases in the liquid phase which will lead to more extensive fluxing and penetration.

Evans, and Cholerton ${ }^{23}$ conducted an experiment involving $\mathrm{V}_{2} \mathrm{O}_{5}$ vapor attack in basic refractories. They observed that dicalcium silicate $\left(2 \mathrm{CaO} \cdot \mathrm{SiO}_{2}\right)$ and monticellite $\left(\mathrm{CaO} \cdot \mathrm{MgO} \cdot \mathrm{SiO}{ }_{2}\right)$, which are initially present in the bonding phase or are produced as a result of batch carryover of silica and $\mathrm{CaO}$, are readily fluxed by $\mathrm{V}_{2} \mathrm{O}_{5}$ to form a low surface tension liquid, which will completely surround and wet the periclase grains and result in significant grain growth. Under a thermal gradient, because of the tendency of the liquid to decrease its free energy upon cooling, such liquid will migrate toward the relatively cooler central region of the brick and could leave outer zones of the bricks devoid of bonding silicates. The problem with forsterite bonded basic bricks is that the batch carryover can radically change the original $\mathrm{CaO} / \mathrm{SiO}_{2}$ ratio from $0.5 / 1$ to about $4 / 1$ which leads to mechanical disintegration. In applications involving no thermal cycling, chrome-magnesites and magnesitechrome refractories in which a second solid phase exists, can resist the $\mathrm{V}_{2} \mathrm{O}_{5}$ attack better than the magnesite bricks. Evans and Cholerton ${ }^{23}$ finally suggested that magnesite bricks should not be used above $1450^{\circ} \mathrm{C}$ $\left(2642^{\circ} \mathrm{F}\right)$ in the presence of vanadium and not above $1500^{\circ} \mathrm{C}\left(2732^{\circ} \mathrm{F}\right)$ in vanadium free atmospheres. Their observations were in general agreement with earlier works by Pressley, ${ }^{29}$ Robijn and Dekeyser, ${ }^{24}$ and Lehman et $a 1.25$

At lower temperatures, sulfates $\left[\mathrm{Na}_{2} \mathrm{SO}_{4}, \mathrm{MgSO}_{4}, \mathrm{CaSO}_{4}, \mathrm{Cr}_{2}\left(\mathrm{SO}_{4}\right)_{3}\right]$ could contribute to the disintegration in the basic bricks due to their accompanying volume expansions. Mörtl and Zednicek ${ }^{26}$ found that in the range $600-900^{\circ} \mathrm{C}\left(1112-1652^{\circ} \mathrm{F}\right)$, the basic bricks are of ten completely spalled in the surface region according to the reaction: 


$$
\mathrm{MgO}+\mathrm{SO}_{3} \rightarrow \mathrm{MgSO}_{4}
$$

Glazer and Boggum ${ }^{27}$ reported that if present, arsenic compounds will catalyze the formation of $\mathrm{SO}_{3}$ and thus increase the formation of $\mathrm{MgSO}_{4}$. The dissociation temperatures of $\mathrm{MgSO}_{4}$ and $\mathrm{CaSO}_{4}$ are $1124^{\circ} \mathrm{C}$ $\left(2055^{\circ} \mathrm{F}\right)$ and $1350^{\circ} \mathrm{C}\left(2462^{\circ} \mathrm{F}\right)$ respectively. Busby and Carter ${ }^{28}$ reported that the rate of formation of $\mathrm{MgSO}_{4}$ is accelerated by the presence of $\mathrm{Na}_{2} \mathrm{SO}_{4}$. Both $\mathrm{V}_{2} \mathrm{O}_{5}$ and $\mathrm{As}_{2} \mathrm{O}_{3}$ increase the formation rate of $\mathrm{MgSO}_{4}$ and reduce its dissociation temperature. In general, sulfate is more detrimental to the basic system than to the aluminosilicate system, mainly because of the reactions of $\mathrm{MgO}$ and $\mathrm{SO}_{3}$.

\subsection{OTHER REFRACTORY SYSTEMS}

Zircon refractories are used mostly in the glass industry. They consist of a zircon phase $\left(\mathrm{ZrSiO}_{4}\right)$ which will decompose into $\mathrm{ZrO}_{2}$ and $\mathrm{SiO}_{2}$ at a temperature of $1200^{\circ} \mathrm{C}\left(2192^{\circ} \mathrm{F}\right)$ in the presence of alkali vapor according to the following reaction: ${ }^{29}$

$$
2 \mathrm{ZrSiO}_{4}+\mathrm{Na}_{2} \mathrm{O} \rightarrow 2 \mathrm{ZrO}_{2}+\mathrm{SiO}_{2}+\mathrm{Na}_{2} \mathrm{O} \cdot \mathrm{SiO}_{2}
$$

The $\mathrm{ZrO}_{2}-\mathrm{V}_{2} \mathrm{O}_{5}$ system has been reported (Fig. 5.11). A low temperature eutectic: $650^{\circ} \mathrm{C}\left(1202^{\circ} \mathrm{F}\right)$ is also present in this system. With sodium vanadate exposure, the following reactions may occur.

$$
\begin{array}{r}
\mathrm{ZrSiO}_{4}+2 \mathrm{NaVO}_{3} \rightarrow \mathrm{Na}_{2} \mathrm{ZrSiO}_{5}+\mathrm{V}_{2} \mathrm{O}_{5} \\
\mathrm{ZrSiO}_{4}+2 \mathrm{NaVO}_{3} \rightarrow \mathrm{Na}_{2} \mathrm{O} \cdot \mathrm{SiO}_{2}+\mathrm{ZrV}_{2} \mathrm{O}_{7}
\end{array}
$$

Unfortunately, the standard free energies of formation for $\mathrm{Na}_{2} \mathrm{ZrSiO}_{5}$ and $\mathrm{ZrV}_{2} \mathrm{O}_{7}$ are not available and thus it is uncertain that the above reactions will occur, or at which temperatures they will occur.

Dolomite refractories, which consist of $\mathrm{CaO}$ and $\mathrm{MgO}$ will be seriously attacked by the combustion product sodium vanadate. of all 


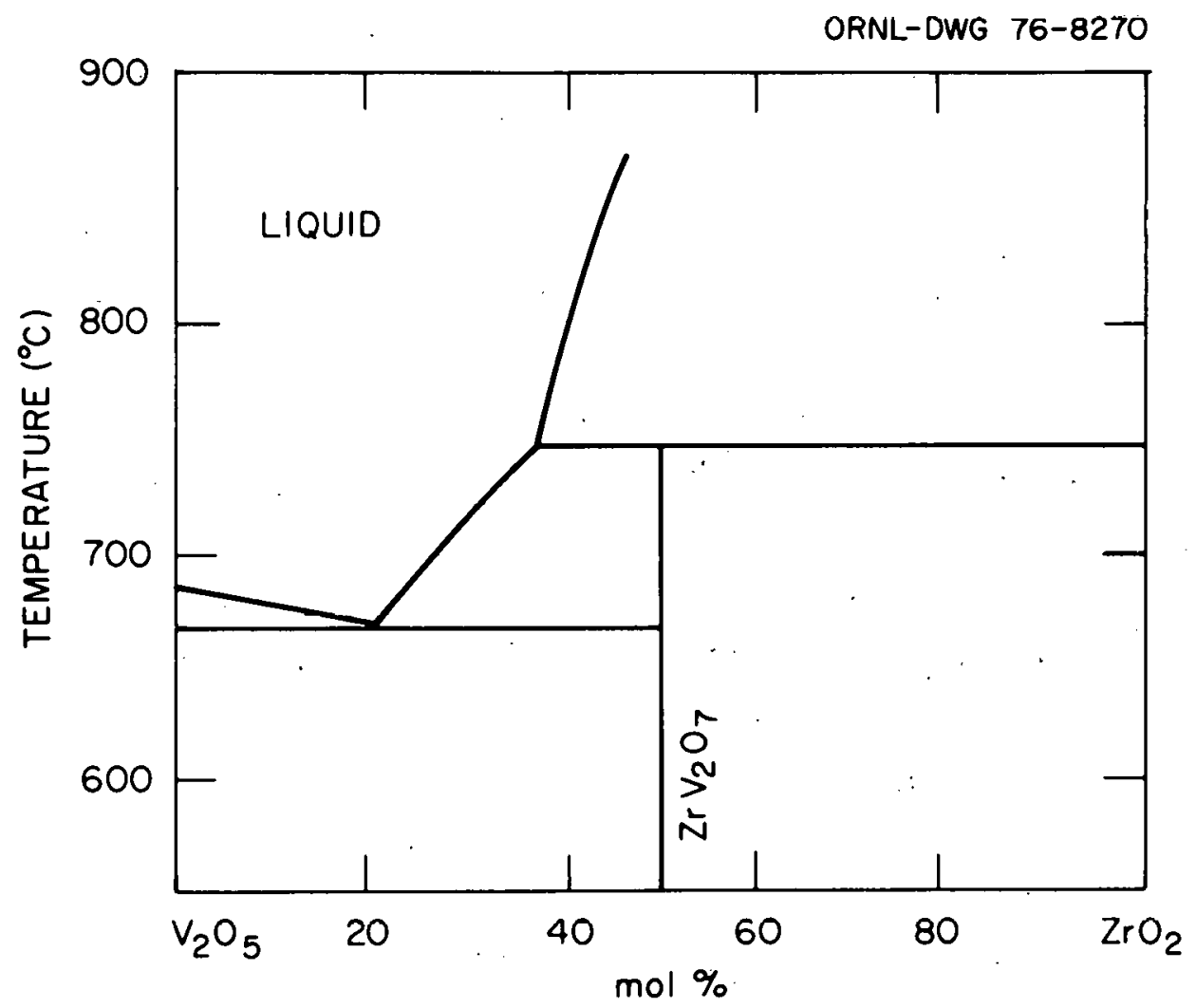

Fig. 5.11. Phase Diagram of the $\mathrm{V}_{2} \mathrm{O}_{5}-\mathrm{ZrO}_{2}$ System. Reprinted with permission from Phase Diagrams for Ceramists, E. M. Levin, C. R. Robbins, and H. F. McMurdie, eds., 1969 Supplement, p. 112, American Ceramic Society, 1969.

refractory types, dolomite refractories are the most susceptible to reaction with $\mathrm{V}_{2} \mathrm{O}_{5}$.

Bratton et al., ${ }^{30}$ have investigated the corrosion rate of $\mathrm{V}_{2} \mathrm{O}_{5}$ and/or $\mathrm{Na}_{2} \mathrm{O}$ in $\mathrm{SiC}, \mathrm{Si}_{3} \mathrm{~N}_{4}$, and silicon-aluminum-oxygen-nitride systems proposed for use in gas turbines. At temperatures as high as $1371^{\circ} \mathrm{C}$ $\left(2500^{\circ} \mathrm{F}\right)$, there is essentially no corrosion, but rather erosion due to the high speed liquid particles of $\mathrm{V}_{2} \mathrm{O}_{5}$ and $\mathrm{Na}_{2} \mathrm{O}$ in the pressurized condition in a gas turbine. 


\subsection{REFERENCES}

1. J. R. Wilson, "Understanding and Preventing Fuel Ash Corrosion," Paper No. 12, Presented at NACE (National Association of Corrosion Engineers) 1976 Annual Meeting, Houston, Texas, March 22-24, 1976.

2. R. C. Kerby and J. R. Wilson, "Solid-Liquid Phase Equilibria for the Ternary Systems $\mathrm{V}_{2} \mathrm{O}_{5}-\mathrm{Na}_{2} \mathrm{O}-\mathrm{Fe}_{2} \mathrm{O}_{3}, \mathrm{~V}_{2} \mathrm{O}_{5}-\mathrm{Na}_{2} \mathrm{O}-\mathrm{Cr}_{2} \mathrm{O}_{3}$, and $\mathrm{V}_{2} \mathrm{O}_{5}-\mathrm{Na}_{2} \mathrm{O}-\mathrm{Mg}$," Can. J. Chem. 51: 1032-40 (1973).

3. W. T. Reid, "Developments Related to Corrosion Problems with Residual Fuel Combustion," World Sixth Petroleron Congress, 151-59 (1967).

4. W. R. Foster, M. H. Leipold, and T. S. Shevlin, "A Simple Phase Diagram Approach to the Problem of 0il-Ash Corrosion," Corrosion 12: $539 t-47 t$ (1956).

5. D. G. Baldwin and P. T. Davis, The $\mathrm{V}_{2} \mathrm{O}_{5} / \mathrm{NaVO}_{3} / \mathrm{Na}_{2} \mathrm{SO}_{4} / \mathrm{SO}_{3}$ Region of the System $\mathrm{Na}_{2} \mathrm{O} / \mathrm{SO}_{3} / \mathrm{V}_{2} \mathrm{O}_{5}, \mathrm{M} 185$, Shell Research, Ltd., Houston, Texas (1958).

6. W. D. Niles and H. R. Sanders, "Reactions of Magnesium with Inorganic Constituents of Heavy Fuel $0 i 1$ and Characteristics of Compounds Formed," Tronsactions of the ASME, J. Eng. Power 178-186 (April 1962).

7. 0. Kubaschewski and E. L. Evans, Metal. Thermochem., 3: 334 (1958).

8. A. W. Coates, J. Inst. Fuel 42: 75 (1969).

9. J. H. Chesters, Refractories Production and Properties, The Iron and Steel Institute, London (1973).

10. J. Williamson, A. J. Tipple, and P. S. Rogers, "The Effect of Vanadium Oxides on the Crystallization of Silicate Glasses," J. Mater. Sci. 4: 1069 (1969).

11. Shimotakahara, "Investigation of the System $\mathrm{V}_{2} \mathrm{O}_{5}-\mathrm{Al}_{2} \mathrm{O}_{3}-\mathrm{SiO}_{2}$," J. Can. Ceram. Soc. 38: 109 (1969).

12. H. Beer and W. Richarz, "Attack of Melts Containing Vanadium on Polycrystalline Alumina," Ber. Dtsch. Kercom. Gres. 50(7): 201 (1974) (Ger.).

13. G. H. Frischat and H. W. Hennicke, "Corrosion of Alumnia by Vanadium Pentoxide Melts," Ber. Dtsch. Kercon. Gres. 51(10): 291 (1974) (Ger.). 
14. S. Okawara and A. Yamaguchi, "Corrosion of Mullite Refractory by Alkaline Vapor," J. Ceram. Soc. Japan 77: 208 (1969).

15. G. R. Rigby and R. Hutton, "Action of Alkali and Alkali-Vanadium Oxide Slags on Aluminosilica Refractories," J. Am. Cerom. Soc. 45(2): 68 (1962).

16. J. R. McLaren and H. M. Richardson, "The Action of Vanadium Pentoxide on Aluminosilicate Refractories," Trans. Brit. Cerom. Soc. 58(3): 188 (1959).

17. M.C.K. Jones and R. L. Hardy, "Petroleum Ash Components and Their Effect on Refractories," Ind. and Engr. Chem., 2615 (November 1952).

18. T. S. Busby, "A Study of the Effect of Fuel Oil Ash on Glass Tank Refractories," Glass Tech. 4(1): 18 (1963).

19. H. Pressley, "Some Effects of Attack on Refractories by the Oxides of Sodium, Sulphur and Vanadium," Trans. Brit. Cerom. Soc. $69(5)$ : 205 (1970).

20. A. V. Morsanyi, "The Effect of Vanadium Compounds on Silica Refractories," Glass Tech. 4(1): 23 (1963).

21. M. Eke and N. H. Brett, "Phase Equilibria in the System CaO-MgO$\mathrm{SiO}_{2}-\mathrm{V}_{2} \mathrm{O}_{5}$ : Their Relevance to Refractory Usage in Glass Tank Regenerators - I. The Particle Systems $\mathrm{MgO}-\mathrm{C}_{2} \mathrm{~S}-\mathrm{V}_{2} \mathrm{O}_{5}$ and MgO-C ${ }_{3} \mathrm{~S}-\mathrm{V}_{2} \mathrm{O}_{5}$ at $1500^{\circ} \mathrm{C}, "$ Trans. Brit. Cercom. Soc. 72(5): 195 (1973).

22. M. Carter and N. H. Brett, "Phase Equilibria in the System CaO-MgO-SiO ${ }_{2}-\mathrm{V}_{2} \mathrm{O}_{5}$ : Their Relevance to Refractory Usage in Glass Tank Regenerators - II. The Partial Systems $\mathrm{MgO}-\mathrm{M}_{2} \mathrm{~S}-\mathrm{V}_{2} \mathrm{O}_{5}, \mathrm{MgU}-$

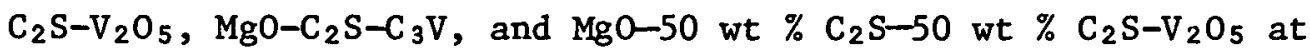
$1450^{\circ} \mathrm{C}, "$ Trans. Brit. Ceram. Soc. 72(5): 203 (1973).

23. G. Evans and J.F.E. Cholerton, "Mechanism of Attack on Upper Course Checker Bricks in Glass Tank Regenerators," Glass. Tech. 13(4): 117 1972.

24. P. Robijn and W. L. Dekeyser, "Changes in Basic Checker Bricks of Glass Furnaces Due to the Heavy Elements of Fuel," Trans. Brit. Cercom. Soc. 69: 169 (1970).

25. H. Lehman, S. Kienow, and P. Artelt, "The Corrosion Resistance of Basic Refractory Bricks to $\mathrm{V}_{2} \mathrm{O}_{5}$," Tonind- $2 \mathrm{tg} 88(7-8): 153$, and 10: 255 (1964). 
26. G. Mort1 and W. Zednicek, Radex Rundschan 1: 406 (1965).

27. W. Glazer and P. Boggum, Verres et Refractaires 20(4): 233 (1966).

28. T. S. Busby and M. Carter, "The Conversion of $\mathrm{MgO}$ to $\mathrm{MgSO}_{4}$ in. Glass Furnace Regenerators," Glass Tech. 12(5): 113 (1971).

29. T. S. Busby, J.I.E. Corney, and J. Eccles, "Zircon Refractories," GZass Tech. 3(6): 190 (1962).

30. A. F. McLean, E. A. Fisher, R. J. Bratton, and D. G. Miller, Brittle Materials Design, High-Temperature Gas Turbine, AMMRC CTR 75-28, 1975. 
6. ANALYSIS OF DEGRADATION MECHANISMS IN

REFRACTORIES AND REFRACTORY INSULATIONS

\subsection{RESULTS}

Many experiments reported in the literature on combustion ash corrosion of refractories used solid-solid or solid-liquid reactions. Normally, such experiments involved mixing the characteristic combustion product compounds such as $\mathrm{Na}_{2} \mathrm{SO}_{4}$ and $\mathrm{V}_{2} \mathrm{O}_{5}$ with the phases of the refractory system of interest such as $\mathrm{Al}_{2} \mathrm{O}_{3}$ and $\mathrm{SiO}_{2}$, or $\mathrm{MgO}$ and $\mathrm{Cr}_{2} \mathrm{O}_{3}$. The samples were usually heated to high temperatures, then quenched and examined to determine the new phase compositions. Alternately, these experiments involve contacting solid-combustion product phases with a piece of test refractory at various temperatures and times. The reaction products formed and strength degradation are later determined. Vapor phase tests reacting $\mathrm{Na}_{2} \mathrm{O}$ or $\mathrm{V}_{2} \mathrm{O}_{5}$ vapor with the refractory more closely simulate actual combustion situations, but these tests have only been done in a few limited cases.

Table 6.1 lists the methods for testing $\mathrm{V}_{2} \mathrm{O}_{5}-\mathrm{Na}_{2} \mathrm{O}-\mathrm{SO}_{3}$ corrosion in the refractories as reported in the literature. The test result normally has direct application only to a limited temperature range and fuel ash composition range. Two degradation modes that have been identified are fluxing, and cracking of the refractory. Actually these two types of deterioration are related. In fluxing, a liquid phase is generated from the low-temperature eutectics existing between the combustion products and refractory oxides. The liquid phase will penetrate the pores in the refractory and later cause spalling and cracking due to thermal stresses generated upon thermal cycling. The cracks thus generated will produce new surfaces to be further attacked by the liquid phase generated by fluxing and thus cause more extensive cracking and spalling. The cracking and spalling result from the formation of new solid phases such as nepheline $\left(\mathrm{Na}_{2} \mathrm{O} \cdot \mathrm{Al}_{2} \mathrm{O}_{3} \cdot 2 \mathrm{SiO}_{2}\right)$, B-alumina $\left(\mathrm{Na}_{2} \mathrm{O} \cdot 1 \mathrm{Al}_{2} \mathrm{O}_{3}\right)$, forsterite $\left(2 \mathrm{MgO} \cdot \mathrm{SiO}_{2}\right), \mathrm{MgSO}_{4}$, and so forth, which have different specific or molar volumes than the host refractory 
Table 6.1. Tests of $\mathrm{J}_{2} \mathrm{O}_{5}-\mathrm{Na}_{2} \mathrm{O}-\mathrm{SO}_{3}$ Corrosion in Refractories

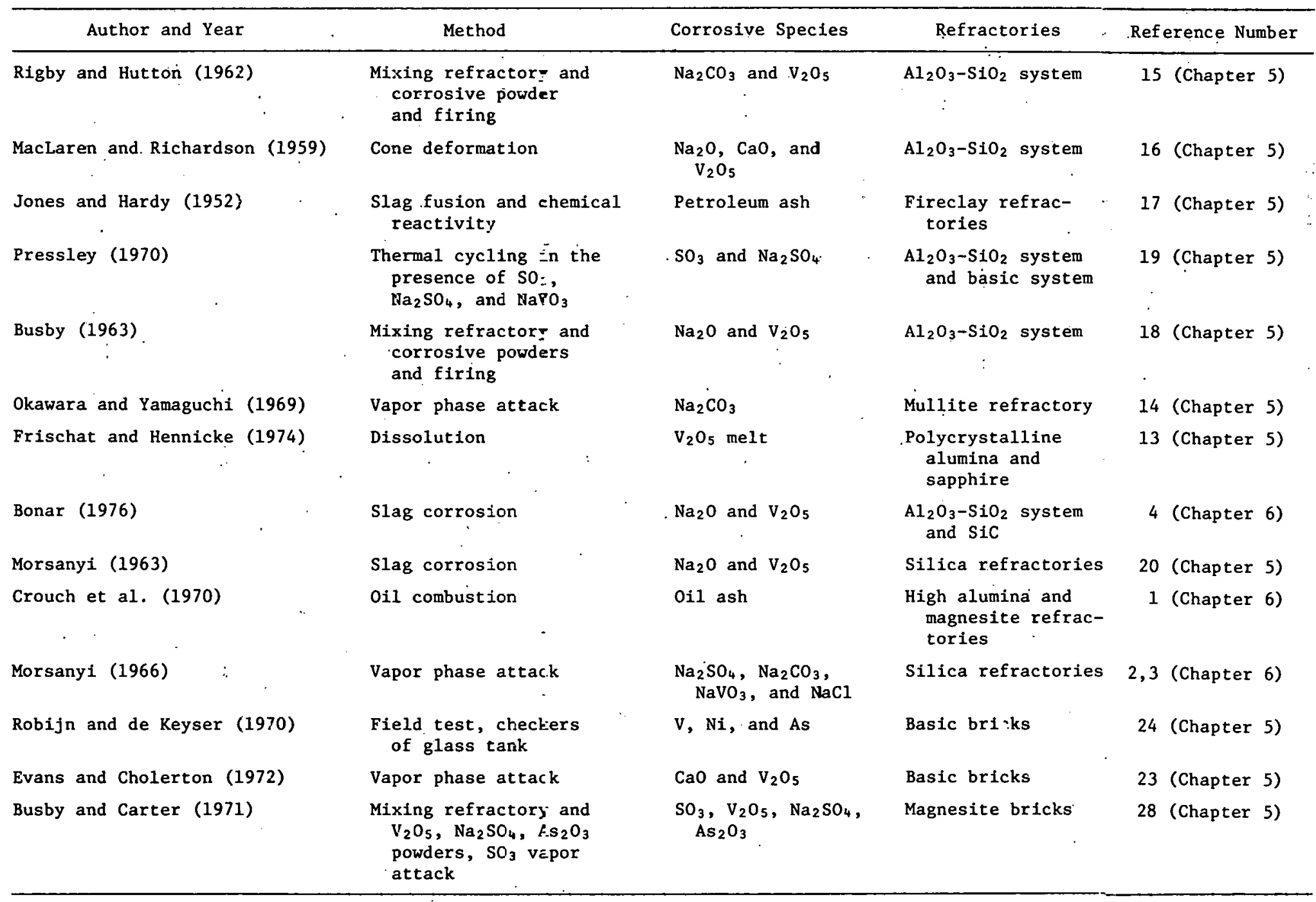


system. The expansion or shrinkage of these new phases relative to the original reactants will generate internal stresses that can cause cracking.

As a first-order approximation, the internal stress generated can be calculated by: ${ }^{5}$

$$
\sigma=\frac{2 E}{3(1+v)} \cdot \frac{\Delta \mathrm{v}}{\mathrm{v}}
$$

where $E$ is the elastic modulus, $\nu$ is Poisson's ratio, and $\Delta v / v$ is the volume fraction expansion or contraction due to the appearance of new phases. Considering thermal cycling, the liquid phase or the new reaction product, which has a different thermal expansion coefficient, will produce a mean linear thermal expansion coefficient for the system, $\alpha_{m}:^{6}$.

$$
\alpha_{m}=\frac{\alpha_{1} f_{1} E_{1} /\left(1-\nu_{1}\right)+\alpha_{2} f_{2} E_{2} /\left(1-v_{2}\right)}{f_{1} E_{1} /\left(1-v_{1}\right)+f_{2} E_{2} /\left(1-v_{2}\right)}
$$

where index 1 and 2 refer to the original phase and the new liquid or solid phase, respectively, $\alpha$ is the thermal expansion coefficient, $\nu$ is Poisson's ratio, $f$ is the volume fraction, and $E$ is the elastic modulus. If the temperature is changed by $\Delta T$, the stress acting on the host phase $\left(\sigma_{1}\right)$ and the new phase $\left(\sigma_{2}\right)$ will be: ${ }^{6}$

$$
\begin{aligned}
& \sigma_{1}=\frac{\sigma_{m}-\sigma_{2}}{1-\nu} E_{1} \Delta T, \\
& \sigma_{2}=\frac{\sigma_{m}-\sigma_{2}}{1-\nu_{2}} E_{1} \Delta T .
\end{aligned}
$$

In the case of aluminosilicate refractories, according to the molecular volumes, the formation of nepheline and alumina by the decomposition of mullite will show a volume contraction of $4.9 \%$ (Table 6.2). The formation of $\beta$-alumina will be accompanied by a volume expansion of $20 \%$. When $\mathrm{Na}_{2} \mathrm{O}$ reacts with mullite or alumina to form $\mathrm{Na}_{2} \mathrm{O} \cdot \mathrm{Al}_{2} \mathrm{O}_{3}$, the volume expansion is $14 \%$. With an assumed elastic modulus of $10 \times 10^{6}$ psi $\left(6.89 \times 10^{9} \mathrm{~Pa}\right)$ and a Poisson's ratio of 0.3 (Eq. 6.1), a compressive stress greater than 700,000 psi $\left(4.82 \times 10^{9} \mathrm{~Pa}\right)$ can be expected when the reaction products mentioned above are formed. Since this is well 
Table 6.2. Selected Thermophysical Properties of Some Refractory Materials

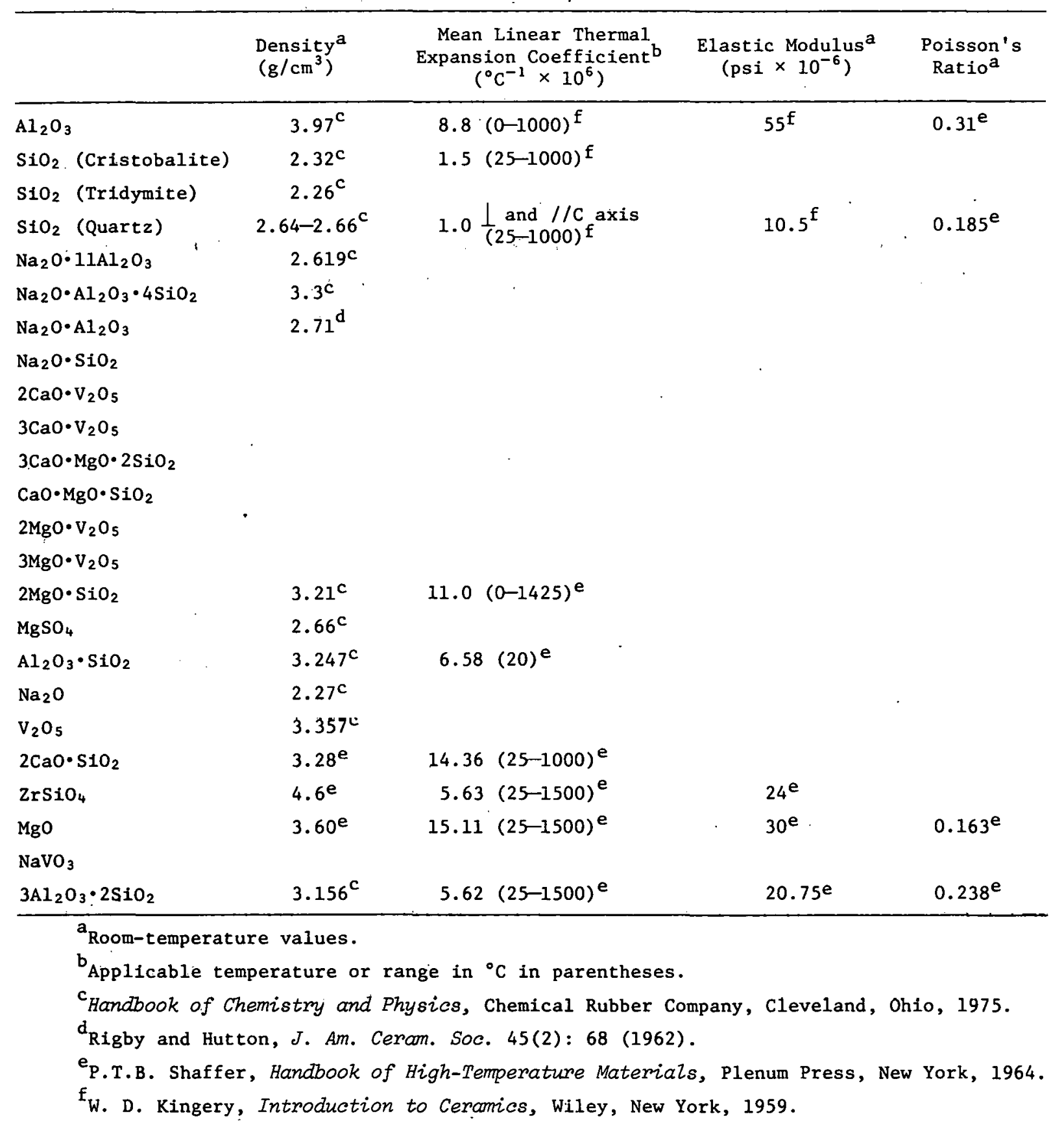


above the fracture strength of most aluminosilicate refractories, ${ }^{7}$ microcracks will probably be generated. In the case of basic refractories, the formation of $\mathrm{MgSO}_{4}$ will cause a volume expansion of $35 \%$. Creation of forsterite $\left(2 \mathrm{MgO} \cdot \mathrm{SiO}_{2}\right)$ from periclase will cause a volume expansion of $12 \%$. A stress on the order of $10^{6}$ psi $\left(6.89 \times 10^{9} \mathrm{~Pa}\right)$ can also be generated in magnesia-chrome refractories by these volume differences. Consequently, spalling throughout the refractory is expected from the formation of these phases.

The porosity of the refractories plays an important role in the degradation due to fluxing and cracking. Since the pores can generally be regarded as a trapping center for the microcracks generated by these stresses, the presence of pores would help to depress the further growth and extensions of the cracks, but would also result in lower initial strengths for the refractory. In fact, pores can stop crack growth to a great extent under certain conditions. On the other hand, the existence of both open and closed pores represents a rapid transport path for the combustion product reactants such as $\mathrm{Na}_{2} \mathrm{O}$ or $\mathrm{V}_{2} \mathrm{O}_{5}$. The corrosive species in vapor or liquid form can penetrate the pore, attack fresh internal surface in the refractory interior, and therefore cause extensive degradation. In addition, the presence of liquid phase among grains may enhance grain growth, lower the creep strength, and weaken the refractory at high temperatures. Microstructural changes are further complicated since liquid phase will migrate from the hot surface to a relatively cooler region in a refractory material with a thermal gradient. This migration then depletes the bonding phase in the region close to the hot surface, with a reduction in the hot strength and an increase in the creep rate of the refractory material. The quantitative aspects of these effects are largely unknown in most of the refractory systems currently used industrially. In view of these effects, dense refractories with small amounts of porosity are superior to more porous ones. In designing a refractory system resistant to fuel ash attack, the use of dense refractories that are relatively inert to the corrosion of the combustion products usually conflicts with considerations of cost and thermal insulation properties, which are typically a direct function of the amount of porosity. 
The formation of liquid phase on the surface of the refractory may act as a barrier to the reaction with the combustion products if the viscosity is high enough. Fluxing and reaction rates depend on four factors: (1) the vapor-solid-liquid reaction at the interface, (2) the transport of the combustion product ions in the melt, (3) the amount of the refractory dissolved in the liquid, and (4) the transport of corrosive ions through the solid phase in the refractories. Each of these four steps could be the rate-determining step in the reaction of the combustion products with the refractory material. Little quantitative data of this type are available for most refractories at present. The most powerful corrosion characteristics of a mixture of $\mathrm{Na}_{2} \mathrm{O}$ and $\mathrm{V}_{2} \mathrm{O}_{5}$ in the alumina-silica system are that both $\mathrm{Na}_{2} \mathrm{O}$ and $\mathrm{V}_{2} \mathrm{O}_{5}$ act as a flux and a mineralizer with the former playing the major role. In the basic refractory system using $\mathrm{MgO}, \mathrm{V}_{2} \mathrm{O}_{5}$ readily fluxes the refractory oxides and $\mathrm{Na}_{2} \mathrm{O}$ tends to make the slag or melt less viscous, and this enhances the corrosion rates. The basic refractory is appropriate to use in an alkali-rich environment and the aluminosilicate refractory is appropriate for a $\mathrm{V}_{2} \mathrm{O}_{5}$ environment, but the combination of $\mathrm{Na}_{2} \mathrm{O}$ and $\mathrm{V}_{2} \mathrm{O}_{5}$ renders either type of refractory prone to serious degradation. Magnesia(ref. 8), dolomite- (ref. 8), SiC- (ref. 9), and $\mathrm{Al}_{2} \mathrm{O}_{3}$-based (ref. 10) additives in fuel oil reduce vanadium corrosion in metal systems. The $\mathrm{MgO}$ reacts with $\mathrm{V}_{2} \mathrm{O}_{5}$ to form $3 \mathrm{MgO} \cdot \mathrm{V}_{2} \mathrm{O}_{5}$, which does not readily react with metallic materials in boilers. This appears to be a potential way to inhibit the corrosion in refractories. Much more research is required to examine the use of additives to prevent corrosion in refractories and refractory insulations.

Another point with regard to the fuel ash corrosion is that the phase diagram data, which represents equilibrium behavior, should be applied with great care to real combustion situations because the fuel ash corrosion reactions in refractories may never reach equilibrium.

\subsection{INTERPRETATION OF FIELD TEST RESULTS}

The field test results of oil ash corrosion in refractories were interpreted on the basis of the mineralogical and chemical examinations 
of the refractories used. However, the results are not always reliable for several reasons: First; the amount of vanadium compounds formed in the bricks is usually small and irregularly distributed. (X-ray diffraction techniques often are not able to detect the expected phases.) Secondly, the compositions of many vanadates are still uncertain and their stoichiometry ranges under the conditions of interest are unknown. (Some vanadates, such as sodium vanadate, desorb oxygen upon cooling and thus change composition. ${ }^{11}$ ) Thirdly, the optical properties of many vanadates are not sufficiently known to permit unequivocal petrographic analysis. (With electron probe microanalysis and other new techniques, it may be possible to identify the elements and their distributions in this type of material.)

With one exception, all the experiments identified in our literature review used solid-solid or solid-liquid reactions. Examinations of refractory field test samples in many of the reported cases often failed to consider that $\mathrm{V}_{2} \mathrm{O}_{5}$ and its compounds, which can form with the common oxides present in the generic types of refractories, have relatively high vapor pressures at the test temperatures. The absence of significant amounts of $\mathrm{V}_{2} \mathrm{O}_{5}$ in the exposed refractories often leads to the possibly false conclusion that $\mathrm{V}_{2} \mathrm{O}_{5}$ does not contribute to refractory deterioration. The $\mathrm{V}_{2} \mathrm{O}_{5}$ may not precipitate in significant amounts at temperatures higher than $1400^{\circ} \mathrm{C}\left(2552^{\circ} \mathrm{F}\right)$. However, the detrimental effect of $\mathrm{V}_{2} \mathrm{O}_{5}$ vapor can be even more serious than the slag containing $\mathrm{V}_{2} \mathrm{O}_{5}$ because the corrosive vapor can permeate through the pores and thereby attack both external and internal surfaces in the refractories.

In the reported interpretations of refractory field test samples, distinctions should also be made between pressurized and nonpressurized environments. Since the liquidus temperatures and the melting points of intermediate compounds in many ternary and quaternary systems involving $\mathrm{Na}_{2} \mathrm{O}$ and $\mathrm{V}_{2} \mathrm{O}_{5}$ strongly depend on the oxygen partial pressure, ${ }^{12}$ degradation in refractories due to $\mathrm{Na}_{2} \mathrm{O}$ and $\mathrm{V}_{2} \mathrm{O}_{5}$ attack will be more serious in those applications involving pressurized oxygen-rich atmospheres.

When. compared with isothermal situations, thermal cycling in applications such as the checkerwork in the regenerator of glass tanks 
increases fluxing, spalling, and cracking. Any thermal gradient in the refractory that increases the microstructural changes involved in the refractory deterioration should also be included in the characterization of the field test samples, and these data have often been lacking from published reports.

In view of the very limited documentations on alternate fuel refractory interactions, an extensive laboratory screening test and a long-term field test are urgently needed. The data base generated will help industries to form a sound, alternate-fuel refractory strategy as the conversion from natural gas to fuel oils and/or coal becomes a major problem of the immediate future.

\subsection{REFERENCES}

1. A. G. Crouch et al., "The Effect of the Combustion Products of Residual Fuel Oil on the Mechanical Strength of High-Alumina and Magnesite Refractories," Trans. Brit. Ceram. Soc. 69: 137 (1970).

2. A. V. Morsanyi, "Silica Brick in the Superstructure of Glass-Melting Furnaces: I. Corrosion of Silica Brick by the Vapor of Sodium Salts," Glass Tech. 7(6): 193 (1966).

3. A. V. Morsanyi, "Silica Brick in the Superstructure of Glass-Melting furnaces: 11. Lorrosion of Silica Brick in the superstructure' and Crowns of Glass-Melting Furnaces," Glass Tech. 7(6): 196 (1966).

4. J. A. Bonar, "Choosing Refractories for Fuel Ash Corrosion Resistance," Paper No. 11, presented at The National Association of Corrosion Engineers 1976 Annual Meeting, Houston, Texas, March 22-24, 1976.

5. J. P. Hirth and J. Lothe, Theory of DisZocations, p. 53, McGraw-Hil1, New York, 1968.

6. W. D. Kingery, Introduction to Ceramics, pp. 479, 630, Wiley, New York, 1960.

7. F. H. Norton, Refractories, p. 288, McGraw-Hill, New York, 1968.

8. J. A. Bonar, "Fuel Ash Corrosion, " p. 76 in Hydrocarbon Processing, August 1972.

9. H. Kirsch, High Temperatures - High Pressures, Vol. 6, p. 545, 1974 . 
10. R. J. Zoschak and R. W. Boyers, "An Experimental Investigation of Fuel Additives in a Supercharged Boiler," J. Eng. Power, ASME, 168 (July 1960).

11. R. C. Kerby and J. R. Wilson, "Solid-Liquid Phase Equilibria for the Ternary Systems $\mathrm{V}_{2} \mathrm{O}_{5}-\mathrm{Na}_{2} \mathrm{O}-\mathrm{Fe}_{2} \mathrm{O}_{3}, \mathrm{~V}_{2} \mathrm{O}_{5}-\mathrm{Na}_{2} \mathrm{O}-\mathrm{Cr}_{2} \mathrm{O}_{3}$, and $\mathrm{V}_{2} \mathrm{O}_{5}-$ $\mathrm{Na}_{2} \mathrm{O}-\mathrm{Mg}, "$ Can. J. Chem. 51: 1032-40 (1973).

12. W. T. Reid, "Developments Related to Corrosion Problems with Residual Fuel Combustion," p. 151-159, World Sixth Petroleum Congress, 1967. 


\section{THIS PAGE}

\section{WAS INTENTIONALLY LEFT BLANK}


ORNL/TM-5592

INTERNAL DISTRIBUTION

1-2. Central Research Library
3. Document Reference Section
4-5. Laboratory Records Department
6. Laboratory Records, ORNL RC
7. ORNL Patent Office
8. D. S. Billington
9. F. L. Culler
10. D. A. Canonico
11. J. E. Cunningham
12. J. H. DeVan
13. R. G. Donnelly
14. W. P. Eatherly
15. W. Fulkerson
16. T. G. Godfrey
7-19. M. R. Hill
20. J. E. Mack
21. W. R. Martin

22. D. L. McElroy

23. C. J. McHargue

24. A. E. Pasto

25. H. Postma

26. M. W. Rosentha1

27. A. C. Schaffhauser

28-505. V. J. Tennery

506. D. P. Stinton

507. D. B. Trauger

508. G. W. Weber

509-518. G. C. Wei

519. J. R. Weir, Jr.

520. C. S. Yust

521. J. Moteff (consultant)

522. Hayne Palmour III (consultant)

523. J. W. Prados (consultant)

524. N. E. Promisel (consultant)

525. D. F. Stein (consultant)

\section{EXTERNAL DISTRIBUTION}

526-535. R. W. Anderson, Division of Buildings and Industry, ERDA

536. B. H. Baker, ARMCO Steel Corp.

537. W. T. Bakker, Fossil Energy Division, ERDA

538. G. T. Ballon, Standard Oil of California

539. E. A. Barrington, Shell 0il Co.

540. W. B. Barton, Borden Co.

541. N. Bernoth, C-E Refractories

542. R. Bernstein, The Mead Corp.

543. D. R. Bisse1 1., Drexel Refractories

544. J. A. Bonar, The Carborundum Co.

545. R. J. Bratton, Westinghouse Electric Corp., Res. Labs

546. R. Britner, Phelps-Dodge Industries, Inc.

547. W. Brossard, Anaconda Aluminum Co.

548. A. Brown, General Motors Corp.

549. B. R. Brown, E. I. duPont De Nemours \& Co., Inc.

550. David Brown, Traneco Inc.

551. C. E. Burley, Reynolds Metal Co.

552. F. Campbel1, Babcock \& Wilcox

553. A. N. Copp, Basic Refractories, Inc.

554. C. Coppin, Southern California Edison, Inc.

555. W. Crawford, El Paso Natural Gas Co.

556. J. A. Crookston, A. P. Green Refractories Co.

557. M. S. Crowley, Standard Oil Co. (Indiana)

558. J. A. Davies, Texaco, Inc. 
559. L. J. Davies, Canadian Refractories Div., Dresser Industries Canada Ltd.

560. T. Deloach, Mobil Oil Corp.

561. D. J. Denmore, True Temper Corp.

562. R. Doersam, Wescor Corp.

563. W. J. Englert, PPG Industries

564. C. R. Enoch, Resco Products, Inc.

565. N. O. Farley, Consolidated Edison of New York

566. C. Farrel, Buckeye International Co.

567. J. Fay, American Smelting and Refining Co. Research Lab

568. W. X. Fay, General Refractories Co.

569. A. D. Fentzke, Emhart Corp.

570. L. E. Ferreira, Interpace Corp.

571. R. E. Ferris, Kaiser Research Center

572. D. G. Frantz, Amoco Oil Co.

573. H. H. Greene, Ohio Lime Co.

574. Richard Grekrila, Westinghouse Research Center

575. F. A. Hals, AVCO Everett Research Lab., Inc.

576. F. Hame1, Gulf Research and Development Co.

577. Douglas Harvey, ERDA

578. H. E. Heddesheimer, General Electric Co.

579. W. W. Heinrich, Phillips Petroleum Co.

580. S. P. Hepburn, ICI Fiber Materials

581. T. D. Higgins, Union Carbide Corp.

582. J. P. Holt, Valley Minerals Products

583. K. K. Kappmeyer, U.S. Steel Corp.

584. R. V. Kilgore, Gunning Refractories

585. L. J. Kuhlman, Monsanto Co.

586. H. F. Kummerle, Owens-Illinois

587. R. G. LaBar, Alcoa Research Labs

588. H. C. Lacy, AISI

589. D. H. Larsnn, Tnstitute of Gas Technology

590. F. A. Layne, Gen Refractories Co.

591. R. Leidner, Bethlehem Steel Corp.

592. R. Limes, Republic Steel Corp.

593. C. Lindsay, TVA

594. B. MacDonald; Kennecott Copper Corp.

595. R. C. Marley, FEA, Industrial Analysis office

596. R. W. Marshe11, North American Manufacture Co.

597. F. M. Maupin, A. P. Green Refractories Co.

598. D. E. McBride, Zircoa

599. J. R. McGaughey, Bickley Furnaces Inc.

600. T. D. McGee, Iowa State University

601. W. Mead, Ferro Corp.

602. B. A. Melass, Celanese Corp.

603. J. I. Moates, General Shale Products Corp.

604. R. J. Moffat, Pullman-Swindel1

605. J. E. Moore, Kaiser Refractories

606. J. Moskowitz, Philadlephia Electric Co.

607. E. D. Miller, Lava Crucible-Refractories Co.

608. R. E. Muchow, Box 337, Niagara Falls, NY 14302

609. J. E. Neal, Johns-Manville Corp. 
610. R. Neeley, Chattanooga Glass Co.

611. J. A. Nelson, University of I1linois

612. R. E. Nelson, C-E Minerals

613. D. Olenchut, Jones and Laughlin Steel

614. P. Papa, Cornhart Refractories Co.

615. J. D. Parsons, Chicago-Wellsville Fire Brick Co.

616. G. Passell, AFC Corp.

617. C. M. Pelanne, Johns-Manville Corp.

618. N. V. Poer, General Motors Corp.

619. R. B. Pool, Kaiser Aluminum and Chemical Corp.

620. S. C. Porter, Jr., Globe Refractories

621. G. V. Prible, C-E Refractories

622. C. J. Ranhke, Power Train and System Research

623. P. H. Reed, New Castle Refractories

624. R. Reed, John Zink Co.

625. D. M. Rice, Davis Fire Brick Co.

626. R. Rose, H. K. Porter Co.

627. R. B. Rosenberg, Institute of Gas Technology

628. R. P. Ross, Glasrock Products, Inc.

629. G. R. Rowland, Hartford Refractories, Emhart Corp.

630. C. K. Russell, U.S. Steel Research Center

631. E. C. Sargent, Kolb Refractories Co.

632. M. Savitz, ERDA

633. F. E. Schmidt, E.I. duPont de Nemours \& Co., Inc.

634. W. E. Scruggs, Monsanto Co.

635. R. L. Schultz, Armco Steel Corp.

636. H. D. Smith, Wellsville Fire Brick

637. H. D. Smith, Westinghouse Research Labs

638. T. E. Smith, Martin-Marietta Cement

639. R. R. Smyth, Fluidyne Engineering Co.

640. W. J. Smothers, Bethlehem Steel Corp.

641. I. Snyder, Dow Chemical Co.

642. D. Stefl, Freeport Brick Co.

643. T. D. Steinke, Kaiser Aluminum and Chemical Corp.

644. D. F. Stock, Harbison-Walker Refractories

645. W. E. Swearingen, Koppers Co., Inc.

646. S. J. Sweeney, Boston Edison Co.

647. Larrie H. Sweet, The Carborundum Co.

648. C. A. Taylor, Shell Oil Co.

649. C. H. Taylor, National Crucible Co.

650. J. W. Tieman, Bituminous Codl Research, Inc.

651. E. A. Thomas, Charles Taylor Div. NL Industries, Inc.

652. C. J. Thompson, Bartlesville Energy Research Center

653. L. J. Trostel, Jr., Norton Co.

654. B. S. Tucker, The Refractories Institute

655. R. Van der Linden, Johns-Manville Products Corp.

656. M. L. Van Dreser, Kaiser Aluminum and Chemical Corp.

657. Theodore. Vojnovich, Westinghouse Research Labs

658. R. L. Walter, H. J. Heinz Co.

659. W. T. Wells, Gulf Oil Co.

660. Alvin Weinberg, Institute for Energy Analysis, ORAU 
661. R. F. Whitford, North American Refractories Co.

662. R. D. Whiting, Coors Porcelain Co.

663. H. R. Wickenden, Goodyear Tire and Rubber Co.

664. R. Wigner, U.S. Steel Research Lab

665. R. Wilcox, Chevron Research Center

666. J. R. Wilson, Shell Development Co.

667. D. Wilty, Commonwealth Edison Co.

668. C. E. Winters, Union Carbide Corp.

66.9. J. Wosinsky, Corning Glass Works

670. Neil Young, International Paper Co.

671. S. Young, Babcock \& Wilcox Refractories

672. C. E. Zimmer, Babcock \& Wilcox Co.

673. USERDA, Oak Ridge Operations Office, Research and Technical Support Division

674-700. USERDA, Technical Information Center 